\title{
SOEMBAWAREESCHE TEKSTEN MET VERTALING
}

\author{
DOOR
}

\author{
Prof. Mr. Dr. J. C. G. JONKER.
}

In leiding, door Dr. P. Voorhoeve.

In den tweeden druk van de Encyclopaedie van Nederlandsch-Indië heeft Prof. Jonker een artikel over het Soembawareesch geschreven. Hij noemt daar ook het weinige dat over deze taal in druk verschenen is, n.l. de woordenlijst van H. Zollinger in Verh. Bat. Gen. DI. XXIII (1850), en een kort verhaal met vertaling en aanteekeningen, door Jonker zelf gepubliceerd in deel 56 van deze Bijdragen (1907). Vermeld hadden nog kunnen worden de talrijke verspreide gegevens in het Kawi-Balineesch-Nederlandsch Woordenboek van Dr. H. N. van der Tuuk, en een woordenlijstje van J. E. Jasper in Tijds. Binn. Best. 34 (1908).

Gedurende den laatsten tijd van zijn leven werkte Prof. Jonker aan een uitgave en vertaling van de overige door hem verzamelde Soembawareesche teksten. Bij zijn dood was het artikel reeds in het net geschreven en gecorrigeerd, en vervolgens door Mevrouw Jonker overgetikt, dus vrijwel persklaar. De getypte copie heb ik nagezien aan de hand van Jonker's manuscript. Tevens heb ik daarbij enkele verschrijvingen verbeterd, de interpunctie regelmatiger gemaakt en alinea's aangebracht. Alle verdere veranderingen heb ik in noten verantwoord.

Alleen het eerste der hier volgende verhalen is niet aan het persklare manuscript ontleend, doch gedeeltelijk aan Jonker's artikel in Bijdr. 56, blz. 273 ev., en verder aan een handschrift uit zijn nalatenschap. De spelling is in overeenstemming gebracht met die der andere stukken. De vertaling van het eerste gedeelte is uit de vroegere publicatie overgenomen; die van het slot heb ik gemaakt met behulp van Jonker's woordenlijst in handschrift. De noten bij dit stuk zijn door mij toegevoegd; in de teksten II-VII heb ik steeds aangegeven of een noot van Jonker of van mij is; de noten bij VIII zijn door mij opgesteld.

In Jonker's nalatenschap, thans in de Universiteitsbibliotheek te Leiden, vindt men over het Soembawareesch nog het volgende materiaal:

Cod. 6300 d, Woordenlijst Smbw.-Maleisch, naar Zollinger. Achterin eenige Smbw. woorden in Arabisch schrift, gedeeltelijk met Maleische vertaling er boven.

Cod. $6300 \mathrm{~b}$ en c, Woordenlijst Smbw.-Hollandsch, naar gegevens van $Z$ (Zollinger), O(?), G(?), de teksten (I-VII geciteerd als B-H, VIII als Gods. Verh. of Gods. Boek), een niet aangetroffen bundel Samenspraken (Smsp.) en de hierna te noemen handschriften. Bij vele woorden staan taalvergelijkende aanteekeningen, voor een deel ontleend aan het woordenboek van Van der Tuuk ${ }^{\mathbf{1}}$ ).

Cod. 6300 a, een net geschreven copie van een verzameling Hollandsche zinnen met Smbw. vertaling. In de woordenlijst wordt naar het origineel hiervan verwezen met V. Aan de andere zijde van het cahier staan, met dezelfde hand geschreven, enkele verhaaltjes vertaald uit het Maleisch, voorkomend in de Handleiding bij de beoefening der Maleische taal- en letterkunde van J. J. de Hollander, en de volledige tekst van het verhaal van Salam (I), welken ik voor de uitgave gebruikt heb.

Cod. 6300 e bevat voorin enkele Makassaarsche woorden met Smbw. vertaling: achterin gégevens over het Rottineesch en nog een andere taal.

1) Een Smbw. woordenlijstje door Van der Tuuk (naar Zollinger) met taalvergelijkende aanteekeningen van zijn hand is te vinden in Cod. 3273. 
Cod. $6300 \mathrm{f}$ bestaat uit Smbw. vertalingen van Maleische zinnetjes uit De Hollander en aanteekeningen naar aanleiding daarvan gemaakt. Dit cahier wordt geciteerd als $\mathrm{H}$.

Cod. $6300 \mathrm{~g}$ bevat voorin verklaringen van woorden en uitdrukkingen uit de teksten I-VII; bij de vertaling van het slot van I heb ik hiervan gebruik gemaakt. Achterin weer Makas.-Smbw., uitvoeriger dan in e, maar toch nog slechts een klein gedeelte van hetgeen in de woordenlijst als $\mathrm{M}$ geciteerd wordt ${ }^{\mathbf{1}}$ ).

De origineelen van de hier gepubliceerde teksten heb ik niet in de nalatenschap kunnen vinden. Vermoedelijk waren ze met Arabisch karakter geschreven. De proeve in Cod. $6300 \mathrm{~d}$ toont aan, dat dit letterschrift voor het Soembawareesch gebruikt wordt, oorspronkelijk uiteraard voor moeslimsch-godsdienstige geschriften ${ }^{2}$ ). Een fragment van zulk een boekje is de laatste tekst (VIII), d.i. het begin van een vertaling van de Maleische catechismus Masā'il almuhtadi li'ichwani-lmubtadi $\left.{ }^{3}\right)$. Handschriften van den Maleischen tekst zijn er vele te Leiden ${ }^{4}$ ) en Batavia ${ }^{5}$ ); ik heb ter vergelijking gebruikt Bat. Gen. 326, Brandes 226 en Sn. H. 91. Er moet ook een lithografische uitgave van bestaan ${ }^{6}$ ). Met behulp van het Maleisch konden verscheidene emendaties in den Soembawareeschen tekst aangebracht worden. Jonker's Nederlandsche vertaling paste daardoor niet overal meer op den tekst, en het kwam mij bovendien overbodig voor haar af te drukken nu het Maleische origineel bekend is. Den Soembawareeschen tekst wilde ik echter niet achterwege laten, al is de taal ook uiterst gewrongen. Men leert er de steevaste vertalingen van allerlei Arabische termen en zinswendingen uit kennen, en er komen enkele grammaticale vormen in voor, die men in de verhalen niet aantreft, zooals de werkwoordsvorm met $i$-, en het pron. poss. van de 3de persoon -na naast het gewone $-n j a$. Jonker's vertaling loopt iets verder door dan de tekst; er volgt nog één vraag en antwoord van de Masā'il, en dan komt het begin van een andere godsdienstige verhandeling. Verschillende fouten in den Smbw. tekst zijn te verklaren als men aanneemt, dat het werkje in Arabisch karakter geschreven was; in Makassaarsch schrift zouden ook de Arabische woorden allicht niet zoo goed bewaard zijn.

Ook in de verhalen komt een enkele maal een, later verbeterde, verschrijving voor als kita voor gita, die op een origineel in Arabisch karakter zou kunnen wijzen. Onzeker is, of Jonker ook de verhalen uit een bestaand handschrift getranscribeerd heeft; het kan zijn, dat hij ze door iemand die het Arabische

1) Materiaal in verschillende stadia van bewerking vindt men in de nalatenschap nog over de volgende talen: Sumbasch, Kupangsch, Amarassisch, Endehneesch, Timoreesch en de talen van Moa en Kisser. Dezen laatsten bundel kende ik nog niet toen Jonker's Lettineesche Taalstudiën gedrukt werden (Verh. Bat. Gen. LXIX, 1932). De aldaar blz. 95 genoemde onbekende bron voor het Moasch (M 2) blijkt een der handschriften van dezen Cod. 6295 te zijn, n.l. de beantwoording van een vragenlijst over moeilijkheden in het Moasch, door Jonker te Leiden opgesteld en beantwoord door E. Malaihollo, gewezen hoofd der Inl. school te Patti op Moa. Bron B zal een dergelijke vragenlijst over het Lettineesch geweest zijn. De Lettineesche samenspraken blijken bewerkt te zijn naar de Maleische in De Hollander's kleine Handleiding tot de kennis der Maleische taal.

2) Ook Jasper noemt het gebruik van Arabische karakters (t.a.p. blz. 104). Zollinger (blz. 171) zegt, dat het Soembawareesch „bijna uitsluitend met Makassaarsch karakter geschreven wordt." Onder de Makassaarsche handschriften uit Jonker's nalatenschap zijn de origineelen der Soembawareesche teksten echter niet aangetroffen.

3) Over de juiste lezing van dezen titel zie men de noot bij het begin van VIII.

4) Catal. Juynboll blz. 286; Suppl. Cat. Van Ronkel blz. 108.

5) Catal. Van Ronkel blz. 397.

6) Opgave van Van Ronkel in den Bataviaschen Catalogus. 
schrift machtig was heeft laten opschrijven. In elk geval zijn het geen voor de gelegenheid gemaakte vertalingen uit het Maleisch, maar behooren ze tot de Soembawareesche volksliteratuur. Ter vergelijking volgt hier een verwijzing naar de mij bekende parallellen in andere talen.

I is een Uilenspiegelverhaal; het is naar Jonker's vertaling in de Bijdragen overgenomen door De Vries, Volksverhalen II no. 119; varianten zijn in de aanteekening aldaar $^{1}$ ) genoemd.

II, een kettingsprookje, is behandeld bij De Vries, Volksverhalen II no. 145. Merkwaardig is het slot met het meisje in de mand; in de Europeesche varianten wordt het meisje vaak in een zak gedragen en vervangen door een hond. $\mathrm{Bij}$ het begin, het zetten van een fuik op het droge, vgl. Rottin., Jonker, Rott. T. no. 24 ; Jaz', MNZ 49 p. 157 ; Sund. TBG 56 p. 113 evv.; Bataksch, Overzicht no. $84 \mathrm{c}$ en $119 \mathrm{~b}$.

III. Vgl. het Bataksche verhaal in mijn Overzicht no. 134, De Vries, Volksverhalen II no. 182 en het tweede ingeschoven verhaal van de door $\mathrm{A}$. F. von Dewall uitgegeven Maleische Hikajat Bachtiar (Brandes TBG 38 p. 237; zie ook TBG 73 p. 432).

IV. Het begin is een variant van het bekende verhaal van den plannenmaker (Perrette enz.), dat ook in de Maleische Hikajat Kalila dan Damina voorkomt, en waarover men verder literatuur vindt bij De Vries, Volksverhalen II no. 143 en L. M. Coster-Wijsman, Uilespiegel-verhalen in Indonesië blz. 65. Van het vervolg, dat handelt over dankbare dieren die helpen een tooverring terug te krijgen, vindt men varianten genoemd bij De Vries, Volksverhalen II no. 170.

$V$ en VI. Hiervan zijn mij geen nauwkeurige parallellen bekend.

VII is door Jonker vermeld in Bijdr. 56 p. 289 . Het is weer een verhaal van het Uilenspiegel-type; zie Coster-Wijsman, blz. 78 no. II en De Vries, Typenregister no. 270. De episoden van het hengelen met pisangs en het stukmaken van de heining worden daar echter niet genoemd.

De taal der verhalen maakt een natuurlijken en, afgezien van enkele Maleische en Makassaarsche leenwoorden, zuiveren indruk. Het is dan ook wel te begrijpen dat Jonker, die veel met stijve vertalingen uit het Maleisch moest werken, voor de bewerking van deze teksten een bijzondere voorliefde had, niettegenstaande stijl en compositie vooral in het langdradige verhaal over Muhammad (V) veel te wenschen overlaten. Jonker's vertaling dient allereerst als hulpmiddel voor het verstaan van den tekst en moest daarom wel letterlijk zijn. Ze doet daardoor stijver aan dan het origineel.

Tot de hier gevolgde spelling van het Soembawareesch is de schrijver blijkbaar eerst op den duur gekomen; in de woordenlijst en het artikel van 1904 wijkt de spelling in kleinigheden af van het hier gevolgde systeem. Bij Van der Tuuk worden vele woorden opgegeven met een slot-hamza, die in Jonker's opgaven ontbreekt, bijv. V. d. T. bociaq. Jonker boa, mond ${ }^{2}$ ). Jonker kende de gegevens van Van der Tuuk en heeft dus blijkbaar de spelling met hamza als onjuist verworpen. In de voorloopige lijst van verkortingen, behoorende bij het woordenboek van Van der Tuuk, staat : „smbw. = sumbawasch, waaruit woorden in sas(aksche) geschriften voorkomen." Het Sasaksch heeft een groote voorliefde voor de hamza als sluiter; wellicht zijn dus Van der Tuuk's gegevens van Sasaksche zegslieden afkomstig.

1) Op blz. 367 r. 2 v.b. lezen men ,oom” in plaats van „broer”.

2) Jasper geeft bowa, maar soms schrijft hij een q, bijv." moeliq = Jonker's $m u l c$, terugkeeren, of zelfs een $\mathrm{k}$, bijv. oedék voor ode, klein, en rangok voor rango, groot. Ook geeft hij soms een $\mathrm{r}$ als sluiter, bijv. air voor ai, water, hisor voor biso, wasschen, en pamoejar voor pamuja, kostwinning. 


\section{I}

Ada sanompo tau miskin, ada anak sopo basingin Salam, ia-antat ngadji. Dadi ling dalam ngadji bĕling děngan: „Kuda lè mu-datang ngadji ?” — „Ku-beang mè asu ode-ku.” - „Kuda mu-patik asu, apa nědjis?” Dadi běling-mo guru: „Na patik asu, Salam, apa nědjis!”

Dapat bale Salam: ,.E, ina, sia-tudja aku baso, olo gula ke njir, apa ia ku-bawa lalo ngadji nawar."

Balangan-mo Salam lalo ngadji; dĕngan rame ngadji, Salam kakan baso. Dadi bĕling guru: „Apa de mu-kakan kau, Salam; bua, no mungadji ?"

„Kadji-kakan tai asu ode."

„Njaman-ke, Salam, tai asu ode?"

Dadi běling Salam: „Njaman, guru.”

„Maeng gadu aku rasa!"

Ia-beang-mo ling Salam lako guru; mĕngka ia-kakan-mo ling guru: „E, njaman tai asu ode, Salam, beang aku sopo, Salam, ame no-mo kangompa guru-mu pina těpong."

Dadi ia-beang-mo ling Salam asu ode sopo lako guru.

„Apa mè asu ode ta, Salam?"

Dadi běling Salam lako guru: „,Mè ke gula ke njir tu-beang.”

„Me lok lamin tu-ete tai?”

„Tu-ěnti nè, tu-ěnti ima, karing tu-ampar, tu-sangka ke pingan lis tai asu ode nan."

Dadi ěnti-mo ling kotap, Salam lalo eneng ai kawa lako guru, batĕris-mo barari Salam. Dadi bĕling guru: „Lalo kělek Salam bawa ai kawa lema!"

Dadi lalo-mo kotap, eneng-mo ai kawa lako guru sowai, Salam ka-mo barari. Dadi inim ai kawa guru, mutu ia-sidu tai asu ling guru, ia-pamung baung, ia-bolang. Ngarai guru: „Lalo buja Salam, ame tu-samate!" 
Er was eens een arm man, die een zoon had, Salam geheeten, dien hij naar school deed gaan. Tusschen het leeren door, zeiden zijne makkers: „Waarom komt gij zoo laat op school?” — „Ik heb mijn hondje eten gegeven." - „Waarom houdt gij er een hond op na, daar die toch onrein is?" Ook de meester zeide: „Houd er geen hond op na, Salam, want die is onrein."

Thuis gekomen, zeide Salam: ,Moeder, stamp, als 't u belieft, voor mij wat mais, en doe er suiker en klapper bij, want dat wil ik morgen naar school medenemen."

Salam ging naar school; terwijl zijne makkers met hun allen aan het oplezen waren, zat Salam mais te eten. Toen sprak de meester: „Wat eet gij daar, Salam; waarom leest gij niet mee?"

„Ik eet den drek van een hondje."

"Is dat lekker, Salam, de drek van een hondje?"

Salam sprak: „Lekker, meester.”

„Kom, laat mij eens proeven!”

Salam gaf het aan den meester; toen deze ervan gegeten had, (zeide hij) : „Hè, wat is die hondendrek lekker, Salam; geef mij ook een (hondje), Salam, opdat uwe meesteres, (mijne vrouw), zich niet meer behoeft te vermoeien om meel te maken."

Salam gaf daarop een hondje aan den meester.

„Wat geeft gij zulk een hondje te eten, Salam?”

Salam zeide tot den meester: „Rijst met suiker en klapper geven wij."

„Hoe gaat 't als wij den drek willen gebruiken?”

„Wij houden (men houdt) zijne voor- en achterpooten vast en dan heeft men hem alleen maar te slaan en den drek, bij het uitloopen, in een bord op te vangen."

De leerlingen hielden nu (den hond) vast en Salam ging (zoogenaamd) koffie vragen aan (de vrouw van) den meester, maar nam meteen de vlucht. De meester sprak: „Gaat heen en roept Salam, dat hij snel de koffie brenge."

(Een) leerling ging heen en vroeg aan de meesteres (de vrouw van den meester) om koffie, want Salam was al gevlucht. De meester dronk de koffie, maar toen hij den hondendrek opschepte, rook hij den stank en wierp den drek weg. De meester werd toornig (en sprak): „Gaat Salam zoeken, opdat wij hem dooden!" 
Lalo tau ode buja Salam, Salam no monda. Dadi mule tau ode nan, ia-bada guru: ,Nonda Salam pang bale; ada sampi ode pang těbongan." - „Lalo ete sampi ode nan, ame tu-sĕmĕle, apa nja Salam no monda." Dadi ia-bawa-mo sampi ode nan lako guru, ia-sĕmĕle.

Dadi mule nja Salam lako bale: „E, ina, me nja sampi-ku, ina ?”„,Ka ia-ete ling guru-mu, anak-e.” — „Lalo eneng pa bau satue.” Lalo ina Salam, ia-eneng lako guru pa satue; nongka ia-beang ling guru. Mule-mo ina Salam lako bale. „Nongka rabeang guru-mu, anak-e, pa sampi." - , Lalo eneng lenong-mo, ina !" Balangan-mo ina, ia-eneng lenong nan lako guru Salam. Dadi ia-beang-mo lenong nan, ia-bawamo mule ling ina nja Salam.

Datang mĕnggĕrib, balangan no nja Salam pĕri puin kaju rango. Dapat puin kaju nan, ěntek-mo ko bao kaju nan nja Salam. Tĕnga pětang datang tau njoro bawa ringgi sapěti, baduman ling anok kaju nan. Dadi běling tau ka ěntek ko bao bale: „Aku tělu ratis, apa aku boat ĕntek.” Bĕling tau ka nangko: „Aku lima ratis, aku boat nangko.” Běling tau gita tau: „Aku nam ratis, apa aku boat gita tau.”

Ia-satěri lenong sampi lako otak tau njoro nan ling nja Salam: ..Ete sarea uwang nan ling kau." Barari sarea tau njoro, ia-bilin ringgi sarea. Turin nja Salam, ia-ete ringgi sarea, ia-bawa mule; dapat bale nja Salam, ia-kibok tělı ratis, ia-bawa ko bale guru.

Dadi bĕling guru: „Ringgi apa ringgi tělu ratis ta, Salam?”„Ka bĕli lenong sampi ka kělam-sĕměle nan.” Dadi běling-mo guru: ,E, tode, lalo sĕmĕle sampi kita sarea, ngo tau, beang isi sarea, kita tu-ete lenong."

Dadi lalo-mo djual lenong ling kotap guru nan, ia-bawa ko kampong Tjina. Dadi rĕga ling Tjina sopo rĕpia. Dadi bĕling tode nan: „Tĕlu ratis ringgi běli salamar.” - „Mana mu-bawa lako Sĕlat, sopo rěpiasi ia-bĕli ling tau; těria mu-bada aku tělu ratis ?' 
Een bediende ging Salam zoeken, maar Salam was er niet. Toen keerde de bediende terug en deelde den meester mede: „Salam is niet thuis; er is een jonge koe onder het huis." - „Ga die koe halen, opdat we haar slachten, omdat Salam er niet is." Toen bracht hij de koe aan den meester; hij slachtte haar.

Salam kwam terug naar huis (en zeide): ,Hé, moeder, waar is toch mijn koe, moeder ?" - ,Je meester heeft hem laten weghalen, kind." - „Ga vragen om een enkel dijstuk." De moeder van Salam ging aan den meester een dijstuk vragen, maar de meester gaf het niet. Salam's moeder ging naar huis terug. „Je meester wil geen runder-dijstuk geven, kind." — „Ga dan de huid vragen, moeder!" De moeder begaf zich op weg, ze vroeg om de huid aan den meester van Salam. Toen gaf hij de huid, en de moeder van Salam nam die mede naar huis.

Toen het avond geworden was, begaf Salam zich op weg en ging naar een grooten boom. Bij dien boom gekomen klom Salam er in. Te middernacht kwamen er dieven met een kist vol rijksdaalders. die gingen onder den boom (hun buit) verdeelen. Degene die het huis binnengegaan was zeide: ,Ik driehonderd, want ik ben boven in het huis gegaan.” Degene die (het gestolene) aangenomen had zeide: ,Ik vijfhonderd, ik heb het aangenomen." Degene die op den uitkijk gestaan had zeide: ,Ik zeshonderd, want mijn taak was, op den uitkijk te staan."

Salam liet de runderhuid op de hoofden der dieven vallen, (terwijl hij riep): „Neem jij al het geld.” Alle dieven gingen op de vlucht, ze lieten al de rijksdaalders achter. Salam klom naar beneden, nam al die rijksdaalders en bracht ze naar huis. Thuis gekomen stopte hij er driehonderd vóór in de plooi van zijn kleed en nam ze mee naar het huis van zijn meester.

De meester sprak: „Wat zijn dit voor driehonderd rijksdaalders. Salam?” - ,Dat is de prijs van de huid van de koe, die U geslacht hebt.” De meester zeide: ..Hé, jongen, ga al onze koeien slachten, roep menschen en geef hun al het vleesch, wij nemen de huiden."

Toen ging een leerling van den meester de huiden verkoopen, hij bracht ze naar de Chineesche kamp. De Chinees bood er één gulden voor. De jongen sprak: ..Ze kosten driehonderd rijksdlaalders per stuk." - ,Al breng je ze naar Singapoera, dan koopt men ze (ilaar toch slechts) voor één gulden; waarom zeg je dan tegen mij driehonderd?" (zeide de Chinees). 
Dadi mule-mo tau ode nan, bawa lenong lako guru. „Ia-eneng ling tau sopo rĕpia bae-si." - „Lalo buja Salam, ame tu-samate.” Dadi lalo-mo buja ling tau ode ko bale nja Salam. Nonda nja Salam ling bale. Mule-mo tau ode nan, ia-bada guru: „Nonda nja Salam, guru-e, bale bae-si ada.” — „Lalo djĕlit bale.”

Ka sucla ia-djĕlit bale nan, datang nja Salam, ia-sapěda api nan, ia-pili arang bale nan, ia-isi lako bosang. Ia dapat ling mĕnggĕrib, lalo-mo nja Salam ko puin kaju nan, ěntek nja Salam ko bao kaju nan kĕbali. Tĕnga pětang datang tau njoro bawa bulaeng dua gutji, batawa ling puin kaju nan. Bĕling-mo satau: „Aku tĕlu gantang, aku tau ka ěntek njoro ko bao bale.” Běling tau nangko: ,Aku nam gantang, apa aku boat nangko.” Běling tau bagita tau: „Aku balu gantang, apa aku boat gita tau."

Ia-tuleng arang lako otak tau njoro nan ling nja Salam: „Ete-mo sarea ling kau!" Barari-mo tau njoro nan satělu. Turin-mo nja Salam, ia-ete bulaeng sarea, ia-bawa mule. Dapat pang ina nja Salam, ia-ete bulaeng nan tĕlu gantang, ia-kibok, ia-bawa lako bale guru.

Běling guru: „Apa de mu-kibok nan, Salam?” — „Ka bĕli arang bale-kadji ka kĕlam-djělit nan; ka kadji-lalo djual ko kampong Tjina, dadi kadji-djual tělu gantang bulaeng sabosang, ia-běli ling Tjina." Bĕling guru: „E, tode, lalo kĕlek guru-mu sowai, ame djĕlit bale nan sadua, ame mu-pili arang, ame mu-lalo djual ko kampong Tjina; tělu gantang bulaeng běli sabosang arang nan."

Ia-lalo-mo bawa ling tau ode arang nan lako kampong Tjina, iaeneng dua sen sabosang. Dadi běling tau ode nan: „Tĕlu gantang bulaeng běli sabosang.” — „Mana mu-bawa lako Sĕlat, sadui běli sabosang, těria mu-bawa ko aku, mu-djual tělu gantang bulaeng! Sai ia běli ?"

Dadi mule-mo tau ode nan, ia-bawa-mo arang lako guru. Dadi běling-mo guru: „Kuda nongka mu-djual arang-mu, tode?” — „Iarĕga ling Tjina dua sen bae-si sabosang; dadi kadji-běling: tĕlu gantang bulaeng bĕli sabosang; dadi běling ke kadji Tjina nan: mana 
Toen keerde de jongen terug en bracht de huiden (weer) aan den meester. „De menschen bieden maar één gulden.” - „Ga Salam zoeken, opdat we hem dooden." De jongen ging Salam zoeken in zijn huis. Salam was niet thuis. De jongen keerde terug en deelde den meester mede: „Salam is er niet, meester, er is alleen maar het huis." - „Ga het huis in brand steken."

Toen hij klaar was met het verbranden van het huis, kwam Salam, bluschte het vuur, raapte de houtskool van het huis op en deed ze in een mand. Toen het tegen den avond liep, ging Salam naar dien boom en klom er weer in. Te middernacht kwamen er dieven met twee kruiken vol goud, die gingen (hun buit) verdeelen onder den boom. Een van hen zeide: „Ik drie gantang, ik ben degene, die naar boven in het huis gegaan is om te stelen." Degene die (het gestolene) aangenomen had zeide: „Ik zes gantang, want ik heb het aangenomen.” Degene die op den uitkijk gestaan had zeide: „Ik acht gantang, want mijn taak was, op den uitkijk te staan."

Salam stortte houtskool uit op de hoofden der dieven, (terwijl hij riep) : „Neem jij alles!” De drie dieven gingen op de vlucht. Salam klom naar beneden, nam al het goud en bracht het naar huis. Toen Salam bij zijn moeder gekomen was, nam hij drie gantang van dat goud, stopte het vóór in de plooi van zijn kleed en nam het mee naar het huis van zijn meester.

De meester sprak: „Wat heb je daar in de plooi van je kleed, Salam?”- „De prijs van de houtskool van mijn huis, dat U in brand gestoken hebt; ik ben ze gaan verkoopen in de Chineesche kamp, en ik heb ze verkocht voor drie gantang goud per mand, (daarvoor) kocht de Chinees ze.” De meester sprak: „Hé, jongen, ga je meesteres roepen, dan moet je die beide huizen in brand steken, de houtskool oprapen, en die gaan verkoopen in de Chineesche kamp; drie gantang goud is de prijs van één mand van die houtskool."

De jongen ging de houtskool naar de Chineesche kamp brengen, (de Chinees) bood twee cent voor een mand. Toen zeide de jongen: „Drie gantang goud is de prijs van een mand.” — ,Al breng je dat naar Singapoera, dan is de prijs (nog maar) één duit per zak; hoe breng je het dan aan mij, om het te verkoopen voor drie gantang goud! Wie zou het (daarvoor) willen koopen?"

Daarop keerde de jongen terug en bracht de houtskool (weer) aan den meester. De meester zeide: ,Waarom heb je je houtskool nog niet verkocht. jongen?" - ..De Chinees bood er maar twee cent per zak voor; ik zei : drie gantang goud is de prijs van een zak; 
mu-bawa ko Sĕlat, sadui ia-bĕli sabosang, mu-datang djual lako ahi: tĕlu gantang bulaeng!” Dadi suru buja Salam ling guru : „Lalo samate nja Salam, tode, lĕga akal aku!"

Balangan-mo tau ode lalo buja nja Salam, barĕma ke guru lako desa. „To no-so-da nja Salam." $\left.{ }^{1}\right)$ Balangan dapat sopo kěban. Ialangka kěban pang nja Salam, dunung bagita nja Salam, mudi guru bagita. Dadi bĕling nja Salam ke sowai : „E, lalo basio kau lema, ame suru turin ina buja gutu-ku, apa to datang guru, ia samate aku."

Dadi tama-mo guru: „E, Salam, ta pang-mu lampa, ku-buja kau bĕlè, bue-mo desa pida-pida, ta pang-mu kau lampa, ia ku-samate kau to." - „No monda, mana ${ }^{2}$ ) ia samate kadji ling guru; sai-mo iabeang mè ulin loka-kĕlam ?" - „Kuda mu-pina sowai tau loka ?” „Gampang-si, guru-e, lamin kadji-roa pina dadara, bau-si dadi.” Dadi bĕling-mo guru: ,Me lok tu-pina, Salam, ame dadi tau dadara?” „Gampang, guru-e.” — „Laga-mo pina tau dadara, ame mo ${ }^{3}$ ) kusamate kau."

Dadi ia-suru ěntek ko bao bale mantua nja Salam, ia-sio bao bale, ia-gulong lenong ling nja Salam, ia-pukil lenong nan: „Loka dadi tau dadara." Ia-sĕlis-mo sowai Salam, ia-sangita guru. „Ta-mo nja ulin loka-kĕlam, dadi dadara.” — „Maeng, beang aku, Salam, kaju nan, ame mo $^{3}$ ) ku-samate kau.” — „Panising-kadji, guru-e.” „Beang aku sule bae-mo solè.” Dadi ia-beang mo ling nja Salam.

Dapat bale guru nan, betak ima sowai, ia-bawa tama ko bilik. Bĕling sowai: „Mangan dunung, guru, mudi tu-lalo ko bilik.” Iabetak ima ling guru, ia-satama ko bilik, ia-pukil: „Loka dadi tau dadara”; ia-pukil: „Loka dadi tau dadara”, sampe mate sowai guru.

1) Volgens de aanteekening in Cod. $6300 \mathrm{~g}$ moet men lezen : desa to. No-soda nja Salam. Bovenstaande opvatting komt echter m.i. beter overeen met het gebruik van to op andere plaatsen in de teksten.

2) ms. : manna.

$\left.{ }^{3}\right)$ mo schijnt hier ,niet" te beteekenen; wellicht verschrijving voor no. 
toen zei die Chinees tegen mij: Al breng je dat naar Singapoera, dan koopt men het (nog maar) voor één duit per zak, en (nu) kom je het aan mij verkoopen voor drie gantang goud!" De meester beval toen Salam te zoeken: „Ga Salam zoeken, jongen, hij houdt mij erg voor den gek."

De jongen ging op weg om Salam te zoeken, samen met den meester ging hij naar het dorp. „Nu is Salam er niet.” Ze gingen op weg tot ze aan een tuin kwamen. Ze betraden de tuin waar Salam was, Salam zag den meester eerder dan deze hem zag. Toen zeide Salam tot zijne vrouw: „Hé, ga je gauw verstoppen, en stuur dan je moeder naar beneden om mij te luizen, want nu komt de meester om mij te dooden."

De meester ging (de tuin) binnen: „Hé, Salam, hier heb ik je nu eindelijk ${ }^{1}$ ), ik heb lang naar je gezocht, alle dorpen, hoevele ook, (heb ik afgezocht), hier heb ik jou nu eindelijk, nu zal ik je dooden.” - „Het doet er niet toe, al wilt U mij dooden; (maar) wie zal dan te eten geven aan Uw oude slavin?” - ,Waarom heb je een oude vrouw getrouwd?" - „Dat is gemakkelijk, meester, wanneer ik haar een jong meisje wil maken, dan kan dat gebeuren." De meester zeide: „Hoe kan men, Salam, iemand tot een jong meisje maken?”- „Dat is gemakkelijk, meester.” — „Komaan, maak haar jong, dan zal ik je niet dooden."

Salam beval zijn schoonmoeder, naar boven in het huis te gaan, hij verborg haar in huis, rolde een huid op en sloeg die huid (terwijl hij zeide): „Oude, word een jong meisje.” Salam liet zijn vrouw naar buiten komen, en liet haar aan den meester zien: ..Hier hebt $\mathrm{U}$ nu Uw oude slavin, die een jong meisje geworden is.” — „Kom, Salam, geef mij dat stuk hout, dan zal ik je niet dooden.” — „Het is een erfstuk van mij, meester." - ,Geef mij het dan maar een poosje te leen." Toen gaf Salam het.

Thuis gekomen vatte de meester zijn vrouw bij de hand en nam haar mee de kamer in. De vrouw zeide: ..Eet eerst, meester, daarna zullen we in de kamer gaan." De meester trok haar bij de hand, hij bracht haar in de kamer en sloeg haar: „Oude, word een jong meisje”; hij sloeg haar: „Oude, word een jong meisje”, tot de vrouw van den meester stierf.

1) lett.: dit is je verblijfplaats waarlijk. 
Ada sopo tau, Pomponge singin, pasang kodong ling těnga rau, kĕna mĕntĕrene; ia-bawa-mo kodong nan, ia-sangaro lako tau patik ajam : „Sangaro gama kodong-kadji ta.” — „Na, nè Pomponge, kěna ia-todok ling ajam.” - „No-si, apa ta ia ku-lalo salagawe.” Mule nè Pomponge salagawe: „Me nja měntěrene-kadji, nè baeng ajam?” — „Ka-mo ia-todok ling ajam.” Dadi běling-mo nè Pomponge: „Pasang kodong těnga rau, kěna měntěrene, todok ling ajam, ajam ta-mo ku-ete!"

Ia-bawa-mo ajam nan ling nè Pomponge, ia-sangaro lako tau nudja. Dadi běling tau nudja: „Na olo ling ninan, nè Pomponge, kĕna ia-dĕpat ling deneng." Mule nè Pomponge: ,Me nja ajam-kadji, nènè nudja?” — „Ka ia-děpat ling deneng.” — ,Deneng ta-mo ku-ete!"

Ia-bawa-mo deneng nan, ia-sangaro lako tau rabara-kĕbo : „Sangaro gama deneng-kadji!” - „Na, nè Pomponge, kĕna ia-rik ling kĕbo!” — „No-si.” Mĕngka mule-mo nè Pomponge: „Me nja denengkadji?” — „Ka ia-rik ling kěbo.” — ,Kĕbo ta-mo ku-ete!”

Dadi ia-bawa-mo kĕbo nan ling nè Pomponge; ia-sangaro lako tau bakĕban-nangka. „Na olo, nè Pomponge, kĕna ia-děpat ling nangka!” - „No-si, ia ku-lalo salagawe sĕ̌ngara.” Mule nè Pomponge: „Me nja kĕbo-kadji, nè baeng nangka?” — „Ka ia-děpat ling nangka.” - ,Nangka ta-mo ku-ete!”

Ia-bawa-mo balangan ling nè Pomponge lako tau dadara nesek: ..Sangaro gama nangka-ku ta, nènè nesek!" -- ..Na, kĕna lis mamong, kĕna kadji-kakan." - .No-si, ia ku-lalo ko bĕrang sěngara.” Mule nè Pomponge ka ling bĕrang: ., Me nja nangka-ku, nènè nesek?" ,.Ka-mo kadji-kakan.” - „Sangaro nangka ko tau nesek, ia-kakan nangka, tau ta-mo ku-ete." 
Er was eens een man, Pomponge geheeten, hij zette een fuik uit midden op het droge veld en daarin geraakte een witte mier; hij nam toen de fuik mede en wilde die in bewaring geven aan iemand, die er kippen op nahield: „Wees zoo goed deze fuik van mij in bewaring te nemen.” - „Laten wij het niet doen, heer Pomponge, de (mier) mocht eens door een kip opgepikt worden.” — ,Neen (geen nood), want ik wil nu mijn gevoeg gaan doen." Toen heer Pomponge terug keerde, (sprak hij): ,Waar is mijn witte mier, heer kippeneigenaar?" - ,Ze is opgepikt door een kip." Toen sprak Pomponge : „Ik plaatste een fuik midden op het droge veld en daarin raakte een witte mier, deze is opgepikt door een kip, deze kip neem ik!"

Heer Pomponge nam die kip mede en bood die aan ter bewaring aan iemand, die aan het stampen was, (en deed dezelfde vraag). Toen zeide de persoon, die aan het stampen was: ,Zet (de kip) daar niet neer, zij mocht eens onder den rijststamper komen." Heer Pomponge keerde terug: ,Waar is mijn kip, heer stamper?” — „Zij is onder den rijststamper geraakt.” — „Dezen stamper neem ik!”

Hij nam den stamper mede en bood dien aan ter bewaring aan iemand, die aan het karbauwen hoeden was: „Wees zoo goed en bewaar mijn bamboezen stamper!” — „Laten wij het niet doen, heer Pomponge, een karbau mocht er eens op trappen!” — „Neen (geen nood)." Heer Pomponge keerde terug: ,Waar is mijn bamboezen stamper?” — „Hij is vertrapt door een karbau.” — „Deze karbau neem ik!"

Heer Pomponge nam vervolgens de karbau mede; hij vroeg die in bewaring te nemen aan iemand die een nangka-tuin had. ,Zet haar (daar) niet neer, heer Pomponge, een nangka mocht eens op haar komen!” „Neen (geen nood), ik wil een oogenblik mij gaan verwijderen." Heer Pomponge keerde terug: ,.Waar is mijn buffel, heer nangka-eigenaar?” - „Een nangka is op haar gekomen.” ,Deze nangka neem ik!”

Heer Pomponge nam de nangka mede en begaf zich naar eene maagd, die aan het weven was: „Wees zoo goed deze nangka voor mij te bewaren, juffrouw weefster!” - „Laten wij het niet doen, de lucht ervan mocht eens uitkomen (bemerkbaar worden) en dan mocht ik ze eens opeten.” - ,Neen (geen nood), ik wil even naar de rivier gaan.” Heer Pomponge kwam terug van de rivier: „Waar is mijn nangka, juffrouw weefster?” — ,Ik heb haar opgegeten.” — „Ik 
Ia-bawa-mo balangan tau dadara nan ling nè Pomponge, ia-sompo. Dadi bĕling tau dadara nan: „Sakit, lamin sompo aku nè Pomponge; buja bosang, kenang isi aku." Ia-buja-mo bosang ling nè Pomponge, ia-tumpan-mo bosang, dua bosang, ia-olo tau sopo bosang, bosang sopo ia-sangisi batu. Ia-lemar ling nè Pomponge, balangan-mo iabawa. Dapat ola maning-tian nè Pomponge. „Tědu kau ling ninta dunung, ia ku-lalo salagawe.” Bĕru salagawe nè Pomponge: „Ko dò sĕdi, nè Pomponge, datang mamong masi tai-kĕlam." Rapina nè Pomponge lako dò. Dadi tau dadara nan ita ia-pina batu, ia sanadi dua bosang. Ia-angkat, sama běrat. Barari tau dadara mule.

Datang nè Pomponge, ia-lemar bosang nan, balangan-mo. Dapat bale, měnggĕrib; eneng lawang ko ina: „Eneng lawang, ina, kubawa mantu-sia.” Dadi běling-mo ina : „Batu, batang rua, anak?”„Mantu-sia sangka datang, eneng lawang, ina, bawa mantu-sia.”„Batu, batang-po rua, anak?” Ia-uleng lawang ling ina, ia-sĕntek-mo bosang ko bao bale. Bĕling-mo nè Pomponge: „Ete mantu-sia, ina!” Bĕru ia-uleng bosang ling ina, barisi batu sadua bosang nan. Dadi běling ina: „,Ka belo ling-ku, anak, ku-kĕtoan kau: batu, batang-po rua, anak, ka ling-kaku; ling-kau: ,mantu-sia sangka datang”, ba ta isi batu lampa bosang ta!"

Kangila nè Pomponge sěmĕle diri.

\section{III}

Ada sopo tau miskin dua ke ina, bale ia-keal ling lonto pona. Dadi tělu tin lè datu Mĕnggĕribi pangidam masin mata ěmpa. Dadi balajar kapal datu Mĕnggĕribi, pitu kapal balajar buja masin mata ĕmpa.

Dadi nja Miskin: „Lalo, ina, barutang pipis bau lima real ko bale 
gaf een nangka in bewaring aan eene weefster, die at haar op, die persoon neem ik."

Heer Pomponge nam het meisje mee op weg, terwijl hij haar op zijne schouders droeg. Toen sprak het meisje: „Het doet mij pijn als gij mij op uwen schouder draagt; zoek eene mand, om mij daarin te zetten." Heer Pomponge zocht eene mand en vond er twee, in de eene zette hij het meisje, de andere vulde hij met steenen. Hij begaf zich, de manden dragende, op weg en voerde het meisje mede. Onderweg kreeg heer Pomponge last van zijn buik. ,Blijf gij hier, ik moet mijn gevoeg gaan doen." Pas was hij daarmede begonnen, (of het meisje zeide): „Ga wat verder af, heer Pomponge, nog hereikt mij de stank van uw drek." Heer Pomponge verplaatste zich wat verder af. Het meisje verplaatste toen de steenen en maakte er twee manden van. Toen zij ze oplichtte waren zij even zwaar. Zij liep snel naar huis terug.

Toen heer Pomponge kwam, begaf hij zich op weg de manden dragende. Toen hij zijn huis bereikte, was het avond; hij vroeg zijne moeder hem de deur te openen: ,Ik vraag toegang, moeder, ik breng "uwe schoondochter." Toen sprak de moeder: „Is het misschien een steen of een boomstam, kind?” - „Uwe schoondochter is het, daarom kom ik, ik vraag toegang, moeder, ik breng u uwe schoondochter.” - „Is het soms een steen of een boomstam, mijn kind?” De moeder opende de deur en hij bracht de manden boven in huis. Heer Pomponge sprak: ,Neem Uwe schoondochter, moeder!” Zoodra de moeder de manden geopend had, (zag zij dat) alle twee steenen bevatten. Toen zeide zij : ,.Ik heb het aldoor wel gezegd, mijn kind, ik vroeg, is 't soms een steen of een boomstam, maar gij zeidet: ,uwe schoondochter is 't, daarom kom ik', en nu bevatten deze manden slechts steenen!"

Heer Pomponge voelde zich te schande gemaakt en verdeed zich.

Er was eens een arm man met zijne moeder, hun huis werd omslingerd door ranken van de laboe. Het geschiedde nu, dat de vorst van het Westen [drie jaar lang ${ }^{1}$ )] (ziek was en) belust was op ingezouten vischoogen. Daarom gingen zeven schepen van den vorst van het Westen onder zeil om ingezouten vischoogen te zoeken.

Toen (sprak) Miskin (de Arme) : ,Ik ga, moeder, geld leenen,

1) Door mij ingevoegd. (P. V.) 
puwa matowa; lamin no sadu tau tu-bajar tĕlu bulan, tu-dadi ulin kita lako baeng uwang." Dapat-mo masa, manang-mo nja Miskin ling boa lawang baeng uwang. Bĕling-mo baeng uwang: „Me lok, lamin no mu-bajar aku tĕlu bulan?” — „Kadji dadi ulin lako kělam.” „Balong-si, Miskin-e, lamin nan ling-kau; ma-mo pipis lima real!”

Ia-bawa-mo pipis nan, manang pang ola, ia-anti tau mule bawa djangan. Dadi bĕling-mo nja Miskin: „Pida běli djangan-kĕlam ta sa-djaran?” Dadi ia-sěmpelek ling tau: „Nasa de mu-kětoan, kenang mu-bĕli mè-mu nonda, apa ampo ia mu-běli djangan-kaku?" Balangan batěris tau bawa djangan nan, datang-mo ampo tau lin, bawa djangan; ia-ěnti boa djaran ling nja Miskin: „Pida běli djangan-kělam ta?” Ia-lanjak-mo nja Miskin: ,Nasa de mu-kětoan, kenang mu-bĕli loto nonda!" Dadi datang-mo tau lin ampo, ia-ĕnti boa djaran ling nja Miskin: „Pida bĕli djangan-kĕlam ta?” Dadi bĕling-mo baeng djangan: „Tělu real běli djangan-ku!” Dadi ia-bajar-mo tĕlu real, ia-bawa-mo ko bale djangan nan, dadi bĕling-mo ko ina-Miskin : „Lalo běli gutji ko bale puwa matowa!"

Dadi balangan-mo ina bawa pipis. Dapat bale puwa matowa: „Apa de mu-buja, ina-Miskin?” — „Ia kadji-bĕli gutji, suru kadji ling ulin-kĕlam nja Miskin.” Dadi bĕling-mo puwa matowa: „Beang gutji ina nja Miskin, tode!" Dadi ia-ete gutji ling tau ode dua nompo, iabeang ko ina nja Miskin. Dadi bĕling-mo ina-Miskin: „Pida bĕli gutji ta, puwa?" Dadi ia-samong ling puwa matowa : ,No-mo běli, ia kenang mu-isi ai pang bale-mu." Dadi ia-bawa-mo mule; dapat bale, ia-gita ling nja Miskin ada-mo gutji dua, ia-bawa mule ling ina.

Ia ete-mo ling nja Miskin, ia-lemar-mo ke ĕmpa, ia-bawa ko bĕrang; dadi dua djaran ĕmpa ia-bawa ko bĕrang. Dapat bĕrang ia-ete modeng-mata ěmpa nan, ia-samelar pěrana ěmpa nan, suda ia-isi-mo ko gutji, ia-bawa mule ko bale. Dadi běling ina: „Me nja ěmpa-mu, anak?” — „Bue ka ku-samelar, modeng-mata ka ku-ete, ku-satama 
ongeveer ter hoeveelheid van vijf rijksdaalders bij den poewa matowa (soort dorpshoofd); als hij ons niet vertrouwt, dat wij hem binnen drie maanden zullen terugbetalen, dan (beloven wij), dat wij in dat geval slaaf zullen worden bij den eigenaaí van het geld." Op zekeren dag ging Miskin aan de deur van den eigenaar van het geld staan. Deze zeide: „Hoe moet het, als gij mij in drie maanden niet terug betaalt?” — „Ik zal dan slaaf bij U worden.” - „Goed, Miskin, als dat uw woord is; hier zijn de vijf rijksdaalders!"

Hij nam het geld mede, ging op den weg staan en wachtte op de lieden die naar huis terugkeerden met hun visch. Toen (er een kwam) zeide Miskin: ,Hoeveel kost deze visch van $\mathfrak{u}$, alles wat op het paard is?” Toen gaf die man hem een oorvijg: „Wat vraag je zooveel, je hebt niet voldoende om er je gekookte rijst mede te koopen, wat wil je dan nog mijn visch koopen?" De man, die de visch met zich voerde, ging door, er kwam weder een ander met visch; Miskin hield het paard aan den bek vast (en zeide): „Hoeveel kost deze visch van u?” De man gaf Miskin een schop: „Wat vraag je zóóveel, je hebt niets om je gestampte rijst te koopen." Toen kwam er nog weder een andere man, Miskin hield zijn paard bij den bek vast : ,Hoeveel kost deze visch van u?” De eigenaar zeide: „Drie rijksdaalders kost mijn visch." Toen betaalde Miskin drie rijksdaalders en nam de visschen mede naar zijn huis en zeide tot zijne moeder: „Ga naar den poewa matowa en koop kruiken!”

Toen begaf de moeder zich op weg en nam geld mede. Toen zij bij het huis van den poewa matowa kwam, zeide deze : „Wat zoekt gij, moeder van Miskin?” - „Ik wil een kruik koopen, daartoe ben ik uitgezonden door uwen dienaar Miskin." Toen sprak de poewa matowa: ,Jongen, geef wat kruiken aan de moeder van Miskin!" De jongen nam twee kruiken en gaf die aan de moeder van Miskin. Toen sprak deze : „Hoeveel kosten deze kruiken, mijnheer ?” De poewa matowa antwoordde: „Zij kosten niets, ze zijn om er thuis het water in te doen." Toen nam zij ze mede naar huis; aldaar gekomen zag Miskin, dat er twee kruiken door zijne moeder mede naar huis gebracht werden.

Hij nam ze en droeg ze met de visch en bracht ze naar de rivier; twee paardenvrachten visch bracht hij naar de rivier. Aldaar gekomen nam hij de oogappels van de visschen, de lichamen liet hij met den stroom wegdrijven, daarna deed hij de oogappels in de kruiken en nam ze mede naar huis. Toen zeide zijne moeder: „Waar zijn uwe visschen, mijn zoon?" - „Ik heb ze alle met den stroom laten 
ko gutji.” Dadi bĕling-mo ina nja Miskin: „E anak-e, těria bue musamelar ĕmpa ka tu-bĕli rarang pipis maung tu-barutang, bue mubolang ĕmpa nan!” Dadi bĕling-mo nja Miskin: „No-si tu-tò kasuka Allah ta ala, ina-e!"

Tu-ete lema ling boa, ia balajar-mo puwa matowa lako Sělat, iamomat-mo bangka puwa matowa; sarat-mo ramomat puwa matowa, ia-roa-mo balajar, lalo nja Miskin ko bale puwa matowa. Dadi bĕling nja Miskin: „Pidan rua kĕlam-balajar, puwa?” Dadi bĕling puwa matowa : „Puan ia ku-balajar.” — „Kadji-njĕmpit gama, puwa, gutji bau dua nompo lako datı Mĕnggĕribi.” Dadi bĕling puwa matowa: „Kĕme tingka nonda tau Měnggěribi pang Sĕlat, ku-bawa-ke mule gutji-mu kěbali ?” Dadi bĕling nja Miskin: „Me ling-kĕlam-mo, puwa-e!" Dadi balajar-mo puwa matowa.

Ete pene, dapat-mo tawa dua ke Sĕlat, batěmong ke kapal ka lis Mĕnggĕribi; bakětoan-mo djuragan kapal: „Bangka ka lis me nan, puwa ?” - „Bangka ka lis Sěmawa, ia ku-lalo ko Sĕlat. Dadi kapal nan me ka lis rua?" Dadi ia-samong ling tau pang bao kapal: „Ka ku-lis Mĕnggĕribi.” Dadi bĕling-mo puwa matowa: „Lamin kapal ka lis Mĕnggĕribi, ada panjĕmpit tau miskin dua gutji lako datu Mĕnggĕribi." Kamĕri djuragan kapal; ia-saturin sěkutji, ia-dajong ko bangka puwa matowa. Dadi ia-ete-mo gutji nan, ia-bawa-mo ko kapal; dapat kapal, ia-gita ling djuragan: „Lalo kĕlek puwa matowa, adjak ěntek ko bao kapal!” Dadi lalo-mo sěkutji kĕlek puwa matowa. Dadi puwa matowa katakit, no tĕngan ia lalo ĕntek ko bao kapal. Dadi ia-sĕntek-mo ko bao kapal ling djuragan, ia-tonda bangka puwa matowa ling kapal, ia-bawa ko Mĕnggěribi. Mutu sa-ng-ano barari kapal, katĕlar bangka puwa matowa. Dadi bĕling-mo sarea dĕngan puwa matowa: „Ta-mo tu-dapat bala, ka langan rea nja Miskin; ta-mo rusak bangka katĕlar, ia-bawa-mo kita lako Mĕnggěribi.”

Mĕngka tu-ete lema, dapat-mo Mĕnggĕribi kapal nan. Ĕntek-mo djuragan, lalo pĕri datu. Dadi ramanik datu nan : ,Ada-ke mu-tumpan ade ka ku-suru buja nan ?” Dadi bĕling-mo djuragan kapal : „Ada-si, 
wegdrijven, de oogappels heb ik er uit genomen $\mathrm{cil}$ in de kruiken gedaan." Toen sprak de moeder van Miskin: ..Mijn zoon, hoe kan je zoo maar de visschen al te maal met den stroom laten wegdrijven. de visschen, die wij duur gekocht hebben voor geld, dat wij geleend hebben; en gij werpt die visschen maar al te maal weg!" Miskin sprak: „Wij weten niet wat de wil van Allah is, moeder!"

Om kort te gaan, de poewa matowa wilde uitzeilen naar Singgapoera en hij bevrachtte zijn vaartuig; toen hij het zwaar beladen had en wilde vertrekken, ging Miskin naar het huis van den poewa matowa. Miskin zeide: „Wanneer wilt ge uitzeilen, mijnheer?” De poewa matowa sprak: „Overmorgen zeil ik uit.” — ..Ik zou cen stuk of twee kruiken willen zenden, heer, aan den vorst van het Westen.” Toen zeide de poewa matowa : „Hoe moet het, als er soms niemand uit het Westen te Singgapoera is, zal ik dan je kruiken weder terugbrengen?” Miskin sprak: „Al wat U zegt, heer, (za! ik volgen)." Toen zeilde de poewa matowa uit.

Om kort te gaan, toen hij halverwege Singgapoera gekomen was. ontmoette hij een vaartuig, dat uit het Westerrijk kwam; de gezagvoerder vroeg: „Van waar komt dit schip, heer?” — „Dit is een vaartuig uit Soembawa, ik wil gaan naar Singgapoera. Van waar komt dit vaartuig van U?" De persoon aan boord van het vaartuig antwoordde: ..Ik kom uit het Westerrijk." Toen sprak de poewa matowa: „Als het een schip is uit het Westerrijk, dan is er een zending van een arme, namelijk twee kruiken, aan den vorst van dat rijk." De gezagvoerder was verheugd; men liet een bootje neer en roeicle naar het vaartuig van den poewa matowa. Toen werden de kruiken aangenomen en naar het schip gebracht; daar zag de gezagvoerder ze (en sprak): „Gaat den poewa matowa roepen, noodigt hem uit hier op het schip te komen." Het bootje voer af om den poewa matowa te roepen. Deze werd bang en durfde niet op het schip; te komen. De gezagvoerder deed hem het schip bestijgen, terwijl zijn vaartuig door het schip voortgetrokken werd en naar het Westerrijk gebracht werd. Toen het schip één dag snel voortgegaan was, kwam het vaartuig van den poewa matowa te zinken. $\mathrm{Al}$ degenen, die met hem op het vaartuig waren, spraken: „Nu hebben wij ongeluk door de schuld van Miskin; nu is het vaartuig gezonken en worden wij medegenomen naar het Westerrijk."

Om kort te gaan, het schip bereikte het Westerrijk. De gezagvoerder ging aan land om zich naar den vorst te begeven. De vorst sprak: „Hebt gij gevonden, wat ik u heb bevolen te zoeken?” Toen D1. 92. 
maeng ko ta!" Koat-mo datu nan, kamĕri ada ia-bawa masin mataĕmpa nan ling djuragan. Dadi ia-sarĕmin sarea tau ling dalam desa. Dadi ramanik-mo datu lako lante-mantěri: „Apa kenang ia ku-balas tau ta, ka sĕmpit aku masin mata-ĕmpa ?" Dadi bĕling-mo sarea lantemantěri : „Tu-balas ke wang, ke bulaeng, ke intan.” Dadi tĕdu datu, ia-pikir. Dadi angkat otak datu: ,Ling dalam ku-sakit nasa medo ku-kenang, nongka ku-těrang, dadi ia ku-balas ke anak-ku." Dadi běling-mo sarea lante-mantěri: „Kasuka dewa!” — „Pina aku pĕti běsi ia lako ku-satama anak-ku!"

Dadi ramanik-mo datu nan: „E matowa, pida ka mu-bĕli bangkamu, pida modal bangka nan sarea?" Dadi běling-mo puwa matowa: „,Dua ribu ka kědjulin-bĕli bangka-kĕdjulin, ke sarea dagang-kĕdjulin dadi lima ribu nasa.” — „E matowa, ete-mo kapal nan ling kau sarea ke momat.” Dadi ramanik-mo datu: „Pidan ia mu-balajar?” Dadi bĕling puwa matowa: „Kasuka dewa!” Dadi ramanik-mo datu: „Nawar mu-balajar!” Dadi ramanik-mo datu: „Laga momat pěti běsi nan, bawa ko kapal puwa matowa!" Dadi ia-momat-mo ling puwa matowa pěti běsi. Dadi kapal datı Mĕnggĕribi sopo ia-lalo antat puwa matowa sanga Sĕlat. Mĕngka dapat-mo Sĕlat, mule-mo kapal datu Mĕnggěribi.

Puwa matowa batěmong ke tau Sěmawa pang Sělat. Dadi bĕlingmo puwa matowa: „Apa rungan desa kita?” Dadi ia-samong ling tau děngan batĕmong nan: „Rungan balong-si, pang desa bue-mo basěděka, sěbab nonda kĕlam mule, dadi tau pang desa kasusa." Dadi ia-samong ling puwa matowa: „To-mo ia ku-mule; kau pidan ia mu-balajar?” — „Nawar, puwa-e!” — „Balong tu-barĕma-mo!”

Dadi, tu-ete lema-mo, dapat-mo desa. Dadi ĕntek puwa matowa, kaměri sarea tau, ia-sawit ke loto kuning puwa matowa. Dadi bĕlingmo puwa matowa: „E tode, lalo isong pěti bĕsi nan, bawa lako bale Miskin!” Dadi bĕling-mo puwa matowa: „Ke aku-mo, tode!” Dadi ia-bawa-mo pěti běsi nan, ia-olo pang angkang bale Miskin. Dadi bĕling puwa matowa: „E Miskin, ta nja pěti běsi, panjĕmpit datu Měnggěribi lako kau.” Dadi ia-samong-mo ling Miskin: „E nanta datu Mĕnggěribi, sěmpit aku pěti běsi, ada-mo pang ku-tunong ling 
sprak de gezagvoerder: „Het is gevonden, brengt het hier!” De vorst stond op, verheugd, dat de gezagvoerder de ingelegde vischoogen gebracht had. Toen werden alle lieden in het land verzameld. De vorst sprak tot de hoofd-mantri's: „Waarmede zal ik dien man beloonen, die mij ingezouten vischoogen gezonden heeft ?" De hoofdmantri's zeiden: „Laten wij hem beloonen met geld, goud en edelgesteenten!" Toen zweeg de vorst en dacht na. Toen hij het hoofd ophief (zeide hij) : „Gedurende mijne ziekte werd ik, hoevele geneesmiddelen ik ook gebruikte, toch niet beter, ik zal hem dus beloonen met mijne dochter.” De hoofd-mantri's zeiden : ,Zooals Uwe Majesteit wil!" - „Maakt mij een ijzeren kist, om daarin mijn kind te doen."

Toen zeide de vorst: „Poewa matowa, voor hocveel hebt gij uw vaartuig gekocht, hoeveel was 't geheele kapitaal (aan waren) in dat vaartuig?" De poewa matowa sprak: .,Uw dienaar heeft zijn vaartuig voor twee duizend gekocht, met al zijne koopwaren, een som van vijf duizend." - „Poewa matowa, neem al die schepen daar met de lading." Toen zeide de vorst: ..Wanneer wilt ge uitzeilen?" De poewa matowa sprak: ,Zooals Uwe Majesteit wil!” Toen zeide de vorst: „Zeil morgen uit!” Toen sprak de vorst: „Laadt die ijzeren kist eens in, brengt ze naar het schip van den poewa matowa." De ijzeren kist werd nu ingeladen door den poewa matowa. Een schip van den vorst van het Westerrijk begeleidde hem tot Singgapoera. Aldaar gekomen keerde het vaartuig van den vorst van het Westerrijk terug.

De poewa matowa trof op Singgapoera iemand uit Soembawa aan. Hij zeide: „Wat zijn er voor berichten uit ons land?” De man, dien hij aantrof, zeide: „Goede berichten, (maar) in ons dorp worden algemeen offermalen gegeven, omdat ge niet teruggekeerd zijt, zoodat de lieden in de plaats in droefheid zijn." De poewa matowa antwoordde toen: ,Thans wil ik terugkeeren; wanneer wilt ge uitzeilen?" - ,Morgen, heer." — „Wij moeten maar samen gaan.”

Het geschiedde dan, om kort te gaan, dat het land bereikt werd. De poewa matowa ging aan land, alle menschen waren verheugd en bestrooiden hem met gele rijst. Toen sprak de poewa matowa: „Jongens, gaat heen en neemt de ijzeren kist en brengt ze naar het huis van Miskin!" Voorts zeide hij: ,.Komt met mij, jongens!" $\mathrm{Zij}$ brachten de ijzeren kist en zetten hem voor het huis van Miskin. De poewa matowa sprak: „Miskin, hier is een ijzeren kist, een zending van den vorst van het Westerrijk aan u." Miskin zeide: „Och, die vorst van het Westerrijk, hij zendt mij een ijzeren kist, dat ik 
bao!" Dapat ling pĕtang, lalo-mo tunong ko bao pĕti, dadi bĕling Miskin: „E nanta datu Měnggĕribi, ka ku-sĕmpit masin dua gutji, těria balas aku ke pěti běsi, ada-mo pang ku-tunong!"

Dadi dapat ling pětang, bĕling-mo anak datu Mĕnggěribi : „Ia ku-lis ko luar ka ling dalam pěti!" Ia-gita-mo Miskin tunong ling bao pěti. Kĕrek Miskin; ia-gita-mo ling lala nan: „E nanta rua tau ta, kĕre nonda, apa nonda, sidjar ka satěpang aku ling datu-ku, ba ta-mo sĕlaki-ku!" Dadi ia-sakoat-mo Miskin : „E ma-mo koat!" Tĕrĕmpat Miskin, turin njĕmbir lako tana. Dadi bĕling lala nan: „Me ia lako mu-barari, ta nja aku sowai-mu, ma-mo ko ta!" Dadi lalo Miskin tama ko dalam pěti, dapat dalam pĕti nan, ia-gita tau sowai balu tokal. Mutu ia-dapat mama, pabua bulaeng ia-kenang.

Dadi tu-ete lema mara ling boa, dadi bĕling-mo lala nan: „Lamin aku karue bitara, ia-mo bua těbok dua ke sĕlaki-ku, sama rua balong!" Dadi dapat ling pětang kĕbali, bĕling-mo lala nan kĕbali: „Lamin aku karue bitara, mu-dadi bale batu kau pĕti bĕsi ke dadi kota lěnang ta sarea!"

Dapat siip djaga, turin tau ko labu; barari lalo bada datu: ,Ada lampa bale balong ia-baning kalepe-kadji, dewa!” — „Me pang?” .,Pang ola kědjulin-lalo ko labu.” Dadi ramanik-mo datu: „Laga bau tau nan, datang bawa rungan bola lako aku!" Ia-bau tau nan, ia-tali. Datang ampo tau lin: „La dewa, ada bale balong ia-baning kalepekadji!”- „Me pang bale nan ?” - „Pang ola, dewa, ia kědjulin-lalo lako labu.” - „Kuda, aku perap ka ku-lalo ko labu, nonda! Bau tau nan, datang bawa rungan bola lako aku!"' Ia-bau-mo tau nan, ia-tali.

Dadi ramanik-mo datu: „E sarian, lalo gita bale nan, tutu-ke ada, lamin nonda, tu-samate tau nan." Dadi lalo-mo sarian, ia-gita ada bale balong ia-liok ling kota. Dadi barari sarian: „La dewa, tutu marua ka kětjap ulin dewa, ada bale balong dalam kota". Dadi ramanik datu: „No-mo tu-samate tau nan, laga lěpas!” Dadi ia-lěpas-mo. 
eene plaats heb om er op te slapen." Toen het avond geworden was, ging hij op de kist slapen en sprak: „Och, die vorst van het Westerrijk, ik heb hem twee kruiken met ingezouten (vischoogen) gezonden en daar beloont hij mij zoo maar met een ijzeren kist, dat ik een plaats hebbe om op te slapen!"

Toen het avond geworden was, zeide de dochter van den vorst uit het Westen: ,.Ik ga eens uit de kist!' Zij zag Miskin boven op de kist slapen. Hij was schurftig; toen hij door de prinses rezien werd (zeide zii) : „Wat een stakkerd is deze man toch, een kain heeft hij niet, niets heeft hij, het is wel natuurlijk dat mijn vorst hem geschikt voor mij beschouwde, dat is dus mijn echtgenoot!" Toen wekte zij Miskin : „Vooruit, sta op!” Deze schrok wakker ‘n sprong van de kist op den grond. De prinses sprak: .,Waar wilt gij heen vluchten, hier ben ik, uw vrouw, kom hier!" Toen ging Miskin in de kist, alclaar zag hij acht vrouwen zitten. Toen zij sirih kauwden, gebruikten zij een gouden sirihdoos.

Om kort te gaan, de prinses sprak: ,Als ik van goddelijke afkomst ben, moge ik en mijn echtgenoot dan op elkander gelijken, als de twee deelen van een gekloofde pinang-noot, beiden even schoon!" Toen het weder avond werd, zeide zij wederom: ,Als ik van goddelijke afkomst ben, worde gij kist dan tot een steenen huis en moge de geheele vlakte tot een versterkte stad worden!"

Toen het vroeg in den morgen was, ging iemand naar de haven: hij ging snel den vorst mededeelen: ..Daar is warachtig een steenen huis, dat 't huis van Uwe Majesteit evenaart!” - ,Waar?” — „Op den weg waarlangs Uw dienaar naar de haven ging." Toen beval de vorst: „Vat dien man eens, hij komt mij leugenachtige berichten brengen!" Men vatte den man en bond hem. Er kwam nog cen andere man: ..O! Majesteit, er is een mooi huis dat het uwe evenaart!" - . Waar is dat huis?” - „Op den weg, dien Uw dienaar wilde gaan naar de haven." - „Hoe kan dat; toen ik gisteren naar de haven ben gegaan, was het er niet. Grijpt dien man, hij komt mij leugenachtige berichten brengen." Men vatte dien man en bond hem.

Toen zeide de vorst: „Bode, ga naar dat huis zien of 't er werkelijk is, zoo niet, dan zullen die lieden gedood worden." De bode ging, hij zag dat er een mooi huis was, ongeven door cen versterkte stad. Hij liep snel (en sprak): ..Heer, 't is waar gelijk Uwer Majesteits dienaren gezegd hebben, er is een mooi huis :n eene stad.” De vorst sprak: .,Die menschen behoeven niet gedoor te worden, laat ze los!" Ze werden losgelaten. 
Dadi ia-sarĕmin sarea tau ling dalam desa ling datu: „Kuda těria ada bale balong nan ia-baning tau? Djina gantjang manang bale ke kota!” Dadi banika datu lalo pěri Miskin: ,,Me-po ka pang kau, těria mu-pina bale batu, mu-pina kota, nongka ia-din kau ling datu, ba ta těnika aku datu ia ku-datang ete kau.” — „Apa sĕbab bua ia mu-ete aku? No ku-roa lalo.” — „Laga-mo basatěrang, apa ia ku-tear kau!” Dadi ia-samong-mo ling Miskin: „Lamin nan-po rua kasuka, balong-si."

Dadi, tu-ete lema ling boa, nawar ia-tear. Dadi pětang, bĕling-mo lala nan: „Lamin aku karue bitara, dadi tau kau rĕbu sarea-mu, ke kěris-tear-mu, ke sĕnapang; laga rabaris, apa nawar ia-tear tau ling datu." Dadi, tu-ete lema, balangan mo datu, ia-lalo tear nja Miskin. Dadi běling-mo lala nan: „Lamin aku karue bitara, turin-mo udjan apit" Ia-saturin ling Allah ta ala udjan api, bue mate sarea tau nan; no monda tau ling dalam desa nan, karing puwa matowa tělas ke sarea děngan.

\section{IV}

Ada sopo tau miskin, balamong karong, basěluar karong, sapu karong, balangan pang amat. Lamin ada tau beang mè, mangan; lamin nonda tau beang mè, no-mo mangan. Dapat masa balangan, ia-sědĕka butil ling tau sopo, ia-bawa-mo balangan butil. Dapat ola, těri butil, běla, nangis Miskin. Datang balangan sopo sudagar: „Apa de mutangis, Miskin?” — „E kadji-nangis, ka bĕla butil-kadji.” Dadi běling sudagar: „Kuda bua mu-tangis butil-mu?” — „Sate-ku sanadi kapal.” Dadi běling sudagar: „Me lok ia mu-sanadi kapal ?” — „Adasi lok, sudagar-e; ia ku-tukar ke ajam butil-ku nan, ku-patik-mo ajam, lěga ajam nan, ku-djual-mo, karing kuběli bebek; ku-djual bebek-ku, ku-běli-mo sampan; ku-djual sampan-ku, ku-bĕli-mo bangka; kudjual-mo bangka-ku, ku-běli-mo sěkonjar; ku-djual sĕkonjar, kuběli-mo kapal.” Dadi bĕling sudagar: „Te tu-lalo ko bale, Miskin, ame ku-beang kau mè." Dadi ia-turit-mo ling Miskin. 
De vorst verzamelde toen alle menschen uit zijn land: „Hoe komt 't, dat er zoo maar op eens dat mooie huis is, dat het onze evenaart? Wel snel staat het huis en de stad!' Toen beval de vorst om naar Miskin te gaan: „Waar komt gij van daan, dat gij zoo maar op eens een steenen huis en eene stad maakt, zonder dat de vorst u kent; thans heeft de vorst mij gezonden om hier te komen en u te vatten!" - „Waarom wilt gij mij vatten? Ik wil niet medegaan." - „Maak u gereed, want anders zal ik u bestrijden." Miskin antwoordde: „Als men aldus wil doen, is het mij goed."

Derhalve, om korte te gaan, den volgenden dag zou er gestreden worden. Toen, om den avond, sprak de prinses: „Als ik van goddelijke afkomst ben, mogen dan alle grashalmen tot menschen worden, met kris en lans en geweer; stelt $\mathrm{u}$ in gelid, want morgen zullen wij bestreden worden door den vorst." Om kort te gaan, de vorst begaf zich op weg, om Miskin te bestrijden. Toen sprak de prinses: „Als ik van goddelijke afkomst ben, dan dale er een vuurregen neder." Allah deed een vuurregen nederdalen en de lieden kwamen al te maal om; er waren geen menschen meer in lat land, alleen de poewa matowa bleef in leven met hen die bij hem behoorden.

\section{IV}

Err was eens een arme man, hij had een baadje van zakkengoed en een broek en hoofddoek van dezelfde stof; hij ging rond op de markt. Als er iemand was, die hem rijst gaf, at hij; als er niemand was, die hem rijst gaf, at hij niet. Op zekeren tijd zoo gaande, werd hem als aalmoes door iemand een flesch gegeven, welke hij met zich medevoerde. Onderweg viel de flesch en brak, Miskin (de Arme) begon te weenen. Er kwam een koopman aangeloopen, (die sprak): „Waarover weent gij, Miskin?” — „Ik ween, omdat mijn flesch gebroken is." Toen sprak de koopman: ,Waarom weent gij over uw flesch?" - „Mijn plan was om er een schip van te maken." „Op welke wijze wilt gij er een schip van maken?” — „Er is een middel, koopman; ik wil mijn flesch ruilen voor kippen, die fok ik op en als zij veel in getal geworden zijn, verkoop ik ze, dan koop) ik eenden; mijne eenden verkoop ik en koop een bootje; ik verkoop mijn bootje en koop een praoe; ik verkoop mijn praoe en koop een schoener; ik verkoop mijn schoener en koop een groot schip." Toen zeide de koopman: „Welaan, laten wij naar huis gaan, Miskin, opdat ik je rijst geef." Toen volgde Miskin hem. 
Mutu dapat bale sudagar, ia-gita ling sowai sudagar: „E kuda ada asu turit mudi, sudagar?” Dadi bĕling sudagar: „Na těkěbir, apa nja manusia ia-mo kita-si.” Dadi běling kěbali sowai sudagar: „Na beang ĕntek ko bale, kĕna tjilaka ia-mo nja kita, suru beang mè ling tana nan-mo!” Dadi bĕling sudagar: „Ěntek ko bale, Miskin!” Sili sowai sudagar: „Pukil, tode, na beang ĕntek asu nan!” Dadi běling sudagar : „Na těkĕbir, no těrang."

Dadi, tu-ete lema, běling-mo sudagar ke sowai : „Ia ku-sukat anakmu ke Miskin." Nangis sowai sudagar, dadi běling sowai sudagar: .,Samate, tode, Miskin, bawa lis lako luar!” Sili sudagar: „Na, tode, lamin mu-bawa, ku-samate kau!" Dadi ia-kĕlek-mo imam, kadi ling sudagar. Datang-mo ko bale sudagar imam, kadi. Dadi bĕling-mo sudagar: ,Nan-si ku-kĕlek tuan imam, tuan kadi, ia ku-sangaro sukat anak-ku ke Miskin." Dadi ia-sukat-mo ling tuan imam ke tuan kadi.

Dadi bĕling-mo sudagar lako nantu nam: „E tode, lalo gita kapal!” Lalo-mo nantu sa-nam, mule ko bale, ia-bada sudagar: „Ka kělar kapal, sudagar-e!” Dadi bĕling sudagar: „Balong-si, anak-e, ame mu-lalo balajar sa-pitu-mu, ame ku-beang kau puin!' Dadi bĕling ade rea nantu sudagar: „Balong-si, sudagar-e!” Dadi ia-beang puin sama lima ribu. Dadi bĕli-mo loto, bĕli-mo kawa, bĕli-mo lenong sa-nam. Dadi Miskin běli loto, bĕli gumbang. Dadi bĕling ade rea : „E Miskin, kudla bua mu-bawa gumbang lako Sĕlat, rena gumbang mura pang Sělat ?” Dadi bĕling Miskin: „Kanga nan-mo rủa dagang-kadji !”

Tu-ete lema, balajar lako Sĕlat sa-pitu. Karing pitu pětang ia-dapat Sĕlat, no monda angin. Dadi tělu bulan lè lino. Dadi bue-mo ai tau nam nan. Dadi běling-mo děngan: „Ada-si ai nja Miskin.” Dadi běling-mo ade rea: „Me lok ia tu-ete ai Miskin, apa ai ka ia-bĕli ling Miskin, kita tu-běli lako nja!” Dadi bĕling Miskin: „Ma-mo bĕli sapulu ringgi sa-gumbang." Dadi ia-běli-mo. Dapat nawar, bue, iaběli ampo. 
Toen zij het huis van den koopman bereikten, zag hen de vrouw van den koopman (en zeide): „Hé, waarom volgt een hond u. koopman?” De koopman zeide: „Wees niet hoogmoedig, want hij is een mensch even als wij." Daarop sprak de vrouw van den koopman weder: „Laat hem niet boven in huis komen, iemand als hij mocht ons tot ongeluk zijn, beveel hem zijn maal daar (buiten) op den grond te geven!” Toen sprak de koopman: „Kom in huis, Miskin!" De vrouw van den koopman werd boos: „Slaat hem, jongens, laat dien hond niet naar boven gaan!" De koopman zeide daarop: ..Wees niet trotsch, dat is niet goed."

Om kort te gaan, de koopman zeide daarop tot zijne vrouw: „Ik ga uwe dochter laten trouwen met Miskin." Zij begon te weenen en sprak: ..Doodt Miskin, jongens, brengt hem naar buiten !" De koopman werd toornig: „Laat dat, jongens, als gij het doet, dood ik jelui!" De koopman liet toen den imam en den kadi komen. Zij kwamen in het huis van den koopman. Deze zeide: „Daarom heb ik mijnheer den imam en mijnheer den kadi doen komen, ik wil hun opdragen mijne dochter met Miskin in het huwelijk te verbinden." Toen werden dezen door den heer imam en den heer kadi gehuwd.

Daarop sprak de koopman tot zijne zes schoonzoons: „Jongens, gaat naar de schepen zien!" Alle zes de schoonzoons gingen heen cn teruggekeerd meldden zij aan den koopman: „De vaartuigen zijn gereed, koopman.” Deze sprak: „Kinderen, gij moet nu met. uw zevenen uitzeilen, ik zal u kapitaal geven!" De oudste van de schoonzoons zeide: „Goed, koopman!” Deze gaf toen aan elk vijfduizend als kapitaal. Alle zes de schoonzoons kochten rijst, koffie, huiden. Miskin kocht rijst en groote watervaten. De eerste (schoonzoon) zeide tot hem: ,Miskin, waarom brengt gij watervaten naar Singgapoera, terwijl zij daar in overvloed aanwezig zijn?" Miskin sprak: „Laat dat nu maar mijn koopwaar zijn!”

Om kort te gaan, alle zeven zeilden uit naar Singgapoera. Toen er nog zeven nachten overbleven voor zij daar zouden aankomen, was er geen wind meer. Drie maanden was er windstilte. Toen raakte het water van die zes lieden op. De scheepsgezellen spraken: ..Miskin heeft nog water.” De eerste der schoonzoons sprak: ..Hoe zullen wij dat water van Miskin nemen, want hij heeft het gekocht? Wij moeten het van hem koopen.” Miskin sprak daarop: „Welaan, de prijs is 10 rijksdaalders per vat." Dus kochten zij het. Den volgenden dag was 't op en kochten zij weder. 
Tu-ete lema, bue-mo ai Miskin, datang-mo angin kĕntjang, dapat Sělat. Badagang sarea, bue-mo sarea dagang ia-djual. Dadi bĕling-mo ade rea: ,Laga-mo sama běli dagang, ame tu-mule!” Dadi běling-mo Miskin: „Balong-si!” Ěntek ko darat Miskin, batěmong ke tau bawa asu. Bĕling Miskin: „Me lako ia mu-bawa asu nan ?” Dadi bĕling tau ode nan: „Ia ku-samate.” — „Maeng, aku-běli tělu ratis ringgi.” Dadi bĕling tau ode nan: „Ma-mo!” Ia-bajar tělu ratis ringgi, ia-etemo asu ling Miskin.

Dapat ola, batěmong ke tau bawa bodok. Bĕling Miskin: „Me lako ia mu-bawa bodok nan, tode?” Dadi bĕling tau ode nan: „Ia ku-samate.” — „Maeng ko ta, ku-běli lima ratis ringgi.” Ia-beang ling tau ode nan, ia-bajar ringgi ling Miskin lima ratis, ia-denan bodok nan ling Miskin.

Dapat ola, batěmong ke tau bawa tikis : „Me lako ia mu-bawa tikis, tode?” — „Ia ku-samate.” — „Maeng ko ta, aku-běli pitu ratis ringgi." Ia-bajar ling Miskin, ia-beang ringgi pitu ratis.

Balangan Miskin, dapat bĕrang, batěmong ke tau mĕramang. Barari tau buja kaju, ia-roa samate ular ling dalam ramang. Dadi běling Miskin : ,Ia mu-kuda ular nan?” — „Ia ku-samate.” — „Maeng ko ta, aku-bĕli sa-ribu ringgi." Ia-bajar-mo ling Miskin, ia-bawa-mo turin ko kapal. Dapat kapal, ia-satama ko dalam korong bĕsi ular nan, asu ia-sat-mo, bodok ia-sat-mo, tikis ia-sat-mo, ia-beang-mo mè sarea.

Dadi bĕling-mo ade rea: „Dagang apa ka mu-bĕli kau, Miskin?” — „Asu ka kadji-bĕli, bodok ka kadji-bĕli, tikis ke ular ka kadji-bĕli, bue-mo uwang-kadji sarea." Dadi bĕling ade lima nantu sudagar nan: „,Sidjar tau tjilaka Miskin, nan nja bua Miskin ling tjilaka, no gĕntuna uwang.” Dadi bĕling ade rea: ,Nan-si lok tau, kanga nan rua ade ia-bĕli ling nja.” Dadli bĕling ade rea nan: „Te-mo, tu-balajar nawar!” Dadi bĕling Miskin: „Balong-si, beang kadji barutang bau dua ringgi, bue uwang-kadji, ia kenang kadji-běli mama, mako!"

Dadi ĕntek-mo Miskin ko darat, ia-bawa-mo asu, ia-bawa-mo bodok, ia-bawa-mo tikis, karing ular ia-bilin pang kapal. Dapat darat, běling Miskin: „Lalo-mo mule, asu, ia samate kau ling tau, ku-bĕli 
Onı kort te gaan, nadat het water van Miskin op was, kwam er een straffe wind en bereikten zij Singgapoera. Zij gingen allen handel drijven en hunne waren verkochten zij altemaal. Toen sprak de eerste der schoonzoons: „Laten wij gezamentlijk koopwaren koopen, opdat wij kunnen terugkeeren!” Miskin zeide: „Goed.” Hij ging aan land en ontmoette een jongen, die een hond met zich voerde. Miskin sprak: „Waar brengt gij dien hond heen?” De jongen sprak: „Ik ga hem dooden.” — „Welaan, ik koop hem voor driehonderd rijksdaalders.” De jongen zeide : „Ziedaar.” Miskin betaalde driehonderd rijksdaalders en nam den hond tot zich.

Onderweg ontmoete hij een jongen, die een kat bij zich had. Miskin zeide: „Waarheen brengt ge die kat, jongen?” Deze zeide: „Ik wil haar dooden.” - „Geef haar hier, ik koop haar voor vijfhonderd rijksdaalders." De jongen gaf haar, Miskin betaalde 500 rijksdaalders en leidde de kat aan een touw voort.

Onderweg ontmoette hij een jongen, die een rat bij zich had: „Waar brengt ge die rat heen, jongen?” - ,Ik wil ze dooden.” — „Kom hier, ik koop ze voor 700 rijksdaalders.” Miskin betaalde en gaf 700 rijksdaalders.

Hij ging voort; aan een rivier gekomen kwam hij bij iemand, die met een werpnet aan het visschen was. Deze liep snel heen om een stuk hout te zoeken, om een slang te dooden, die in het net gekomen was. Miskin sprak: „Wat wilt ge met die slang doen?” — „Ik wil ze dooden.” - „Geef haar hier, ik koop ze voor duizend rijksdaalders." Miskin betaalde het geld, en nam (de dieren) mede aan boord. Aldaar deed hij de slang in een ijzeren kooi, den hond, de kat en de rat bond hij vast en gaf allen te eten.

De eerste (der schoonzoons) sprak: „Wat voor koopwaar hebt ge gekocht, Miskin?” - „Een hond heb ik gekocht, een kat heb ik gekocht, een rat en een slang heb ik gekocht en al mijn geld is op." Toen zeiden de andere vijf schoonzoons van den koopman: „Het kan wel niet anders of Miskin is een ongelukskind, dat is de oorzaak, dat hij in de ellende is, hij weet niet met geld om te gaan." De eerste schoonzoon sprak: ,Zoo gaat 't met de menschen, zoo is nu eenmaal wat hij koopt.” Toen zeide hij : „Welaan, laten wij morgen uitzeilen!” Miskin sprak: „Goed, geef mij een rijksdaalder of twee te leen, want mijn geld is geheel op, om daarvoor sirih, enz. en tabak te koopen."

Vervolgens ging Miskin aan land en nam den hond, de kat en de rat mede, alleen de slang liet hij op het schip. Aan land gekomen, zeide Miskin: „Ga terug naar uw plaats, hond, de menschen wilden 
njawa-mu.” Dadi běling asu: „Lamin ada susa-kĕlam, kĕlek kadji, ada-mo kadji pang bale-kĕlam.” Dadi běling ko bodok: „Lalo-mo, bodok-e, mule, ka-mo ku-bĕli njawa-mu!” Dadi bĕling bodok : „Lamin ada susa-kělam, kělek kadji, ada-mo kadji pang bale-kělam." Dadi běling-mo Miskin ko tikis : „Lalo-mo mule, tikis-e, ka ku-bĕli njawamu!” Dadi bĕling tikis : „Lamin kělam-susa, kĕlek kadji, ada-mo kadji pang bale-kĕlam."

Tu-ete lema, turin Miskin ko kapal, balajar; dapat těnga lit, iasĕlis ular ling dalam korong běsi, ia-beang mè. Njĕmpong ular ko dalam lit, ia-turit ling Miskin. Ia-turit barari dalam ai. Tu-ete lema, dapat desa naga. Dadi bĕling sarea tau ling dalam desa nan: „To nja datu-kita mule; ada tau turit mudi, apa rua ka anung bua ia-turit ling tau ?” Dapat bale naga, gita anak, kaměri naga: „E sĕlamat, anak-ku, ada mule!" Ia-riwa ling bapa, nja Miskin ěntek ko bale naga nan. Dadi bĕling-mo anak naga nan: „E bapa-e, na nja tau ka běli njawa-ku, ia samate aku ling tau. Apa kenang tu-balas nja Miskin ta?” Dadi běling-mo bapa: „Uleng gĕdong nan kenang bajar Miskin !'” Dadi bĕling anak naga nan lako bapa : „No-po ku-satĕpang, bapa-e, ke uwang sopo gĕdong nan.” Dadi běling bapa: „Ta sisin, ta-mo kenang ku-balas Miskin, apa de ia-ĕnti, lamin ada sisin nan, dadi bulaeng sarea.” Dadi bĕling bapa naga nan: „E Miskin-e, lamin masi mu-bata-bata, laga ĕnti tiang bale ta, dadi bulaeng !" Bĕru ia-ěnti ling Miskin, dadi bulaeng tiang bale nan. Dadi ngamit-mo nja Miskin, basĕlaman-mo: „To ku-mule aku, naga-e !’ Dadi bĕling naga nan: „Lamin ada susa-mu, Miskin-e, ngo aku, ada-mo aku pang bale-mu."

Dadli balangan Miskin dalam ai; dapat tĕntang ka pang njĕmbir, ěntek-mo ko bao, ada kapal. Dadi běling ade rea: „Ana nja adi Miskin, lalo ete !' Saturin sěkutji, ia-lalo-mo ete. Ĕntek ko bao kapal.

Tu-ete lema, barari kapal, dapat desa. Bĕling sudagar: „E to nja mule kapal anak-kita !' Kamĕri suclagar. Ěntek-mo sa-nam ko darat, karing Miskin mesa pang kapal. Dadi bĕling sudagar: „Apa rungan, tode ?”- , ,Rungan balong, sudagar-e, laba sarea dagang-kadji !" - 
u dooden, maar ik heb uw leven losgekocht." Toen sprak de hond: „Als u in moe:lijkheden komt, roep mij dan, ik zal in uw huis zijn." Hij zeide tot de kat: „Ga terug, kat, ik heb u 't leven gekocht." De kat zeide: ,Als u in moeilijkheden komt, roep mij, ik zal in uw huis zijn.” Toen zeide Miskin tot de rat: „Ga terug, rat, ik heb u 't leven gekocht.” De rat sprak: „Als u in moeilijkheden zijt, roep mij, ik zal in uw huis zijn."

Om kort te gaan, Miskin begaf zich aan boord en men zeilde uit; in volle zee gekomen, liet hij de slang uit de ijzeren kooi, om haar eten te geven. De slang sprong in zee en Miskin haar achterna. Hij volgde haar snel in het water. On kort te gaan, zij bereikten het land der naga's. De inwoners zeiden: „Hier komt onze prins terug; een mensch volgt hem, waarom wordt hij door dien mensch gevolgd ?". Gekomen in de woning van den naga-vorst, zag deze zijn zoon en sprak verheugd: „Heil, mijn zoon, dat gij terug zijt!” Zijn vader nam hem op schoot, Miskin besteeg onderwijl het huis. De zoon van den naga sprak: „Vader, deze is de man, die mijn leven losgekocht heeft, toen men mij wilde dooden. Waarmede zullen wij Miskin vergelden?” Toen zeide de vader: „Open dat pakhuis, om daarmede Miskin te betalen." De zoon van den naga zeide tot zijn vader: „Ik beschouw hem niet voldoende betaald, vader, met dat eene pakhuis vol goud.” 'Toen zeide de vader: „Deze ring hier, hiermede zal ik Miskin beloonen, alles wat hij in de hand neemt, als hij die ring aan heeft, wordt goud!” Hij sprak: „Miskin, als gij nog twijfelt, vat dan deze huisstijl aan, zij zal van goud worden!" Pas had Miskin haar aangevat, of de huisstijl werd van goud. Toen nam Miskin afscheid en onder het handen geven (zeide hij) : ,Nu ga ik naar huis, naga!” De naga sprak: „Als ge in moeilijkheden zijt, roep mij, Miskin, ik zal in uw huis zijn.”

Daarop begaf Miskin zich op weg in het water; toen hij gekomen was in de richting waar hij in 't water gesprongen was, kwam hij boven en daar waren de schepen. De eerste der schoonzoons zeide: „Daar is onze jongere broeder Miskin, gaat hem aan boord nemen." $\mathrm{Zij}$ lieten een boot neer en gingen hem opnemen. Hij kwam nu aan boord.

Om kort te gaan, de vaartuigen gingen snel voort en bereikten hun land. De koopman sprak: ,Wel, thans zijn de schepen van onze kinderen teruggekeerd!" Hij was verheugd. Alle zes (de schoonzoons) gingen aan land; alleen Miskin bleef aan boord. De koopman sprak: „Wat is er voor nieuws, jongens?”- „Goed nieuws, koopman, 
„Me nja adi-mu Miskin ?” — „Ana pang kapal.”

Dadli bĕling adle lima: „Tau tjilaka Miskin, sudagar-e; untung dlagang-nja sarea, bue uwang ka bĕli asu, běli bodok, bĕli tikis, běli ular.” Dadi ia-samong ling sudagar: „Nan-si lok tau; lamin untung bae tu-badagang, no monda tau rara; sakali untung, dua kali rugi, nan nja lok tau tu-badagang."

Dadi bĕling sowai sudagar: „Nan nja rua tau tjilaka mu-lalo pina nantu, apa-mo nan uwang bue ia-sarusak." Dadi bĕling sulagar: ,.Sabar, lamin untung tu-badagang, ka-mo tu-sugi.”

Dadi tu-ete lema, běling sudagar lako anak rea: „Ma lalo běli kapal!" Lalo-mo anak bĕli kapal, nam kapal ia-bĕli, dadi ia-duman sama sopo; ia-beang puin sama sapulu ribu, běli loto, bĕli kawa, běli sarang. Balajar-mo ko Sělat.

Dapat Sĕlat, ia-djual-mo dagang, sama untung sarea. Bue ia-djual dagang sarea, bĕling-mo nantu rea sudagar nan : „Laga-mo tu-rablanja, ame tu-mule!” Bĕling-mo sarea: „Balong-si.” Nja Miskin běling ko sarea mĕntĕris: „Lalo rablanja, ěntek ko darat !” Dadi ia-beang ringgi sarea mĕntěris bĕli tĕpong, běli kěre, bĕli djangan. Nawar ĕntek, ia-beang-si blanja. Tu-ete lema, bue-mo uwang Miskin. Dadi bĕling-mo nantu rea sudagar nan: „Apa dagang ka mu-bĕli kau, Miskin?” — „Nonda dagang kadji-bĕli.” — „Me lako uwang pĕno nan ?” — „Bue kenang bĕli těpong, bĕli kĕre, sapu sarea.” Dadi bĕling anak rea sudagar nan: „E Miskin, bue lampa ùwang-mu?” Dadi iasamong ling Miskin: „Sa-kepeng no monda.” — „Balong-si ame tubalajar nawar.” Dadi bĕling Miskin: „Balong-si, beang gama kadji barutang bau sa-pulu ringgi, kenang ia bĕli mama, mako."

Dadi běling-mo nantu rea sudagar nan: „Nawar tu-balajar-mo, adi.” Dadi běling Miskin: „Balong-si !” Dadi bĕling nja Miskin : „E tode, lalo ĕntek ko darat, sarĕmin tai djaran ke tai sampi, momat ko kapal ta !” Dadi běling sarea mĕntěris: „Balong-si.” Dadi ia-angkit tai djaran, tai sampi. 
al onze koopwaren hebben winst opgeleverd." - „Waar is uw jongere broeder Miskin?” - „Daar op het schip."

Toen zeiden de vijf (jongere schoonzoons): „Miskin is een ongeluksmensch, koopman; met al zijne koopwaren is hij gelukkig geweest, maar al zijn geld is op door 't koopen van een hond, een kat, een rat en een slang." De koopman antwoordde: „Zoo is 't Jot der menschen; als wij alleen maar winst behaalden bij het handelen, waren er geen armen meer; éénmaal maakt men winst, tweemaal lijdt men verlies, zoo is 't lot van ons, als wij handel drijven."

Toen sprak de vrouw van den koopman: ,Zoo is dat ongeluksmensch, dien gij tot schoonzoon gemaakt hebt, zoodat al het geld door hem weggemaakt is.” De koopman sprak : ,Geduld, als wij (steeds) winst maakten in den handel, waren wij reeds rijk geworden!"

On kort te gaan, de koopman zeide tot den eersten schoonzoon: „Welaan, ga schepen koopen!” Deze ging schepen koopen, zes schepen, en aan ieder werd er een toebedeeld; hun werd gegeven ieder een kapitaal van tienduizend, zij kochten rijst, koffie, eetbare vogelnestjes. Zij zeilden naar Singgapoera.

Aldaar gekomen verkochten zij hunne koopwaren, op alles maakten zij winst. Nadat zij alles verkocht hadden, zeide de oudste der schoonzoons van den koopman: „Laten wij inkoopen gaan doen, om terug te kunnen gaan!" Allen zeiden: „Goed.” Miskin sprak tot de matrozen: „Gaat aan land en doet inkoopen!” Hij gaf aan ieder der matrozen rijksdaalders om meel, kleeren en visch te koopen. Den volgenden dag, bij het aan land gaan, gaf hij weer geld voor inkoopen. $\mathrm{Om}$ kort te gaan, al het geld van Miskin was op. Toen sprak de eerste der schoonzoons: „Wat voor koopwaren hebt gij gekocht, Miskin?” - „Ik heb geen koopwaren gekocht.” — „Waarheen is al dat vele geld gegaan?” - „Het is opgegaan met het koopen van meel, kain's, hoofddoeken." De oudste schoonzoon van den koopman ze.de: „Wel, Miskin, is werkelijk uw geld op ?” Miskin antwoordde : „Ik heb geen duit meer.” — „Wij moesten morgen maar onder zeil gaan.” Miskin sprak: „Goed, maar geef mij als 't u belieft een stuk of tien rijksdaalders te leen on daarvoor sirih met toebehooren en tabak te koopen."

De eerste der schoonzoons van den koopman sprak: „Morgen zeilen wij dus uit, jongere broeder.” Miskin zeide : „Goed!” Hij zeide voorts (tot de matrozen): ,Jongens, gaat aan land, verzamelt dc uitwerpselen van paarden en runderen en laadt ze in 't schip." $\mathrm{Zij}$ zeiden: „Goed.” Toen droegen zij dat aan. 
Tu-ete lema, sapěno kapal, balajar-mo siip djaga. Dadi bĕling nantu lima sudagar: „Beang kapal Miskin dunung, apa kĕna ilang, apa bue uwang tau ia-kakan, apa nonda modal kapal." Dadi balajar, ia-iring kapal Miskin. Parak ke desa, siip djaga, ilang kapal Miskin, no monda ia-gita. Dadi bĕling nantu rea sudagar nan: „Me nja kapal nja Miskin ?” Dadi bĕling sa-lima: ,No monda, ka-mo barari.” Dadi ia-samong ling nantu rea sudagar nan: „Tu-mule-mo kita, siong tĕntu desa lako, ame njaman tu-buja."

Tu-ete lema, dapat desa, ia-gita ling sudagar: „To nja mule kapal anak-mu, sopo kapal nonda ku-gita." Dadi běling sowai sudagar: „Kapal asu tjilaka no monda, nan nja ade ilang.” Dadi ĕntek sarea nantu sudagar. Dadi bĕling sudagar: „Me nja adi-mu Miskin ?”„Kadji-mĕleng siip djaga, no monda kapal-nja kadji-gita.” Dadi bĕling sowai sudagar: „Sangka ku-běling ke sudagar: na beang modal pĕno ke tau tjilaka mĕnan rua; mu-beang-si."

Dadi tu-ete lema, nawar siip ada-mo kapal Miskin pang palabu. Dadi ia-gita ling sudagar : „Ana nja kapal Miskin.” Dadi běling sowai sudagar: „,Me-po pang ada tau tjilaka mĕnan, ka-mo barari !” No-po ka lè ka běling měnan, těria ada ěntek Miskin. Dadi běling sudagar: „,̌́ntek ko ta, anak !' Dadi bĕling nja Miskin: „Ling ninta-mo kadji, nan-si nja, tingka ${ }^{1}$ ) sala, kadji-datang pĕri kĕlam, ia kadji-pasila kělam lako kapal.” Dadi běling sowai sudagar: „Apa ia mu-kĕlek sĕlaki-ku? Siong nongka gita kapal sĕlaki-ku, ia mu-lalo adjak turin, apa uwang bue ka mu-balobang !” Dadi běling sudagar: „Na bĕling měnan, no tĕrang; mĕlè adjak tau, tu-lalo."

Běling-mo sudagar: „E tode, saturin sĕkutji-ku nan ling tĕbongan, ia ku-lalo ko kapal !" Ia-saturin ling ulin sudagar sĕkutji nan, ete pajung sudagar, balangan-mo. Dapat sisi lit, ia-gita sĕkutji nja Miskin, dajong ka sělaka sarea. Dadi běling sudagar: „Ku-ola sěkutji-kau,

1) Volgens anderen: sinta. (J. C. G. J.) 
Om kort te gaan, nadat zij 't schip vol geladen hadden, zeilden zij vroeg in den morgen uit. De vijf andere schoonzoons van den koopman zeiden: „Laat 't schip van Miskin vooraan, want 't mocht eens wegraken; al ons geld toch heeft hij opgemaakt, zoodat 't schip zonder kapitaal is." Zij zeilden dan uit en volgden het schip van Miskin. Nabij hun land gekomen, vroeg in den morgen, was het schip van Miskin verdwenen en werd niet meer gezien. De eerste schoonzoon van den koopman zeide: „Waar is het schip van Miskin?” De vijf overigen spraken: „Het is er niet meer, hij is gevlucht.” De eerste antwoordde: „Laten wij naar huis gaan, het is niet zeker naar welk land hij gegaan is, dat wij hem gemakkelijk kunnen zoeken."

Om kort te gaan, toen zij hun land bereikten, zag hen de koopman: „Thans zijn de schepen uwer kinderen teruggekeerd, één schip zie ik niet.” Daarop zeide de vrouw van den koopman: „Het schip van den ongelukshond is er niet, dat is 't, dat weg is." Toen kwamen al de schoonzoons aan land. De koopman zeide: „Waar is uw jongere broeder Miskin?” - „Toen wij vroeg in den morgen ontwaakten, zagen wij zijn schip niet meer." De vrouw van den koopman zeide: „Ik heb daarom tegen den koopman gezegd: geef niet zooveel kapitaal aan zoo een ongeluksmensch, maar gij gaaft het toch."

Om kort te gaan, den volgenden dag vroeg was het schip van Miskin op de reede. Toen de koopman dit zag (zeide hij): „Daar is het schip van Miskin!” De vrouw van den koopman zeide: ,Waar zou zoo een ongeluksmensch zijn? hij is gevlucht." Niet lang nadat zij dat gezegd had, kwam Miskin op eens aan land. De koopman sprak: „Kom hier boven in huis, mijn zoon.” Miskin zeide: „Laat mij maar hier blijven, daarom, als $u$ 't mij niet kwalijk neemt, kom $\mathrm{ik}$ tot $\mathrm{u}$ : ik wilde $\mathrm{u}$ uitnoodigen aan boord te komen." De vrouw van den koopman sprak: „Wat wilt ge mijn man roepen? Mijn man heeft toch wel al eens een schip gezien en nu zult ge hem uitnoodigen aan boord te komen, terwijl al het geld door je doorgebracht is!” De koopman sprak: „Spreek zoo niet, het is niet goed; telkens als men ons uitnoodigt, gaan wij."

Hij zeide: ,Jongens, brengt die sloep van mij, uit de ruimte onder het huis, te water, ik wil naar het schip gaan." De slaven van den koopman brachten de sloep in 't water, de koopman nam een zonnescherm en begaf zich op weg. Aan den zeekant gekomen, zag hij de sloep van Miskin, de roeiriemen waren geheel van zilver. De koopman zeide: „Ik zal van uw sloep gebruik maken, mijn zoon.” D1. 92. 
anak-e.” Dadi bĕling nja Miskin: „Balong-si, sudagar-e.” Bĕling sudagar lako ulin: „Lalo sĕntek sěkutji kěbali, olo ko tĕbongan!” Dadi sudagar batĕris ko kapal. Dapat mbao kapal sudagar, bĕling-mo ko nantu: „Apa ade mu-bawa kau, anak?” Dadi běling Miskin: „Sila, uleng bongkang-peta!” Mutu ia-uleng ling sudagar, ia-gita ngamir bulaeng ke intan. Kaměri sudagar, ěntek-mo ko darat sudagar.

Dapat darat, bĕling ko ulin sudagar: „E tode, laga sĕlis gambir ling dalam gudang ta ke bĕndala, sĕlis sarea, sabrĕsi gudang bau ěmpat!” Dadi ia-sabrěsi gudang ěmpat. Běling sowai sudagar: „Apa ade ia-bawa ling asu tjilaka, gambir ke bĕndala ling dalam gudang bue tu-sĕlis ?” Dadi turin-mo sudagar ko kapal: „Laga-mo isi bĕlase nan intan ke bulaeng!" Ia-isi-mo mĕntĕris Miskin. Dadi bĕling sudagar: „E tode, běru dapat angkang bale, sangampas bělase nan, mu-těri barěma ke nja kau, ame ia-gita ling puwa-mu!" Dapat angkang bale sudagar, ia-sangampas bĕlase nan, barĕma ke nja tĕri. Ia-gita ling sowai sudagar, kaměri sowai sudagar ia-gita intan ke bulaeng pěno: „Koat lema balong, koat lema balong!” Koat-mo měntěris. Ia-kětoan ling sowai sudagar : „Apa ade ia-momat kapal-mu sarat ?” Dadi běling měntěris : „Bulaeng ke intan bae-si, puwa-e, nonda ade lin." Ia-měnong bĕling měnan měntěris nan ling sowai sudagar, kamĕri sowai sudagar: „E nanta anak-ku si Miskin, lĕga lampa bulaeng ke intan ia-bawa ling anak-ku!"

Dadi, tu-ete lema, ia-angkit bulaeng ke intan nan, dadi sapĕno ĕmpat gudang. Dadi dapat ling pětang, bĕling-mo Miskin: „E tode, lalo bawa sama sa-bĕlase beang sowai-mu!" Dadi mĕntĕris ete bĕlase sama sopo, ia-isi bulaeng ke intan. Dadi bĕling Miskin : „Lema turin mudi, tode, kěna tò tau ling sudagar, sili ka ku-beang nènè bulaeng!" Dadi ěntek měntěris sarea, Miskin mesa ling bao kapal. Dapat bale mĕntěris nan, ia-olo bĕlase ko bao tilam. Dadi bĕling sowai mĕntĕris nan: „Apa isi bĕlase nan, mu-olo ko pang tu-tunong ?” Dadi bĕling sĕlaki: „Penang kau, kěna mĕnong tau ling sudagar, kěna sili tau; bulaeng ke intan isi bĕlase nan, ka beang tau ling djuragan sarea kami 
Miskin sprak: „Goed.” De koopman zeide tot zijne slaven: „Brengt de sloep weer aan land en plaatst die in de ruimte onder het huis!" Toen ging hij door naar het schip. Op het schip gekomen, zeide hij tot zijn schoonzoon: „Wat voert gij mede, mijn zoon?” Miskin sprak: „Open het laadruim, als 't u belieft!" Toen de koopman het geopend had, zag hij goud en diamanten glinsteren. Verheugd ging hij aan land.

Aldaar gekomen zeide hij tot zijne dienaren: „Jongens, doet de gambir uit de pakhuizen en de pakken; doet alles er uit en makt een stuk of vier pakhuizen schoon." Toen werden vier pakhuizen schoon gemaakt. De vrouw van den koopman zeide: „Wat heeft die ongelukshond medegebracht, dat de gambir en de pakken al te maal uit de pakhuizen gedaan worden?" De koopman ging (weer) aan boord: „Vul eens deze zak met goud en diamanten!” De zak werd gevuld door de matrozen van Miskin. Toen sprak de koopman: „Jongen, zoodra gij voor mijn huis gekomen zijt, smijt de zak dan neer en laat $u$ tegelijk met die zak vallen, opdat uwe meesteres het ziet!" Toen hij voor het huis van den koopman gekomen was, smeet hij de zak neer en liet zich tegelijk vallen. De vrouw van den koopman zag het en was verheugd bij het zien van de vele diamanten en het vele goud: „Sta mooi vlug op, sta mooi vlug op!” De matroos stond op. De vrouw van den koopman vroeg: „Waarmede is uw vaartuig vol geladen?” De matroos sprak: „Alleen met goud en diamanten, mevrouw, er is niets anders." Toen de vrouw van den koopman den matroos dit hoorde zeggen, was zij verheugd: „Och die zoon van mij, die Miskin, mijn zoon heeft wel veel goud en diamanten medegebracht!"

Vervolgens, om kort te gaan, werd het goud met de diamanten overgebracht en vulde vier pakhuizen. Toen het avond was, zeide Miskin: „Jongens, neemt ieder een zak mede voor uwe vrouw!" Ieder der matrozen nam toen een zak en vulde die met goud en diamanten. Miskin sprak: „Komt daarna snel aan boord, jongens, de koopman mocht het eens te weten komen, wat wij doen; hij zou boos zijn, dat ik ulieden goud gegeven heb." Alle matrozen gingen aan land, Miskin bleef alleen op het schip. Toen de matrozen te huis kwamen, legden zij de zak op hun matras. Hunne vrouwen zeiden: ,Wat is er in dien zak, dat gij hem op onze slaapplaatsen legt?" Hare mannen spraken: „Zwijg gij, wij mochten eens door den koopman gehoord worden en dan zou hij wellicht boos worden; goud en edelgesteenten zijn in dien zak, onze gezagvoerder heeft ons allen 
sama sa-bĕlase kami, no-mo beang aku mè, apa to ia ku-turin ko kapal sarea kami, apa djuragan mesa-mesa ling kapal; kĕna tò tau ling sudagar, sili-mo."

Dadi turin měntěris ko bao kapal, dadi bĕling djuragan: „Ta kuĕntek ko darat, tode!" Dadi ia-sěntek ko darat djuragan, ia-bawa těromol sopo ko bale djuragan nan; dapat-mo bao bale, běling djuragan ke mĕntĕris: „Lalo turin ko kapal kau, aku mudi ku-turin.” Dadi běling sowai djuragan: „No-so ka-ke beang kau ling sudagar bulaeng?” — „Nongka beang tau ling sudagar.” — „Tu-sabar-mo; lamin nongka beang tau, siong ada puin-kita."

Tu-ete lema, turin Miskin ko kapal. Siip djaga sowai Miskin uleng těromol, ia-gita sisin sě-pa dalam tĕromol; nonda ada lin isi. Dadi ia-satama sisin nan ko ima sowai Miskin, siip djaga ete pěrku tĕbok kaju sowai Miskin. Pĕrku dadi bulaeng, kaju dadi bulaeng.

Ia-gita sisin polak pang ima; kasusa sowai Miskin, ia-bawa ko tukang mas. Dadi bĕling sowai Miskin : „Ma pidjar sisin ta, ku-upa kau tělu pulu ringgi!” Dadi bĕling tukang bulaeng: „Lalo mu-mule, era aku-bawa mudi”. Dadi mule sowai Miskin. Dadi ete palu tukang bulaeng, mutu ia-ěnti palu, dadi bulaeng, ia-ete sěpit, dadi bulaeng. Dadi barari tukang ia-pĕrari sisin.

Dapat bale Miskin, ia-kětoan sowai : „Me lako sisin ta?”- „Ka polak, mutu ku-těbok kaju, ka ku-suru satěrang tukang.” — „Lalo gita tukang, lema!" Ia-lalo gita tukang nan, ka barari. Dadi sowai Miskin kasusa-mo. Dadi běling nja Miskin: „No-mo pina susa; laga pina mè lěge, sapisak, sakuning, saputi, siong bĕte; apa-apa de datang něngka, na těrěmpat, apa ia ku-kĕlek sarea!"

Mutu ia-kĕlek asu, datang-mo sapěno karang; ia-kĕlek bodok, sapěno karang; ia-kĕlek tikis, sapĕno bale ling tikis; ia-kĕlek ular, sapĕno karang. Dadi bĕling-mo Miskin : „Ada susa-ku aku, no monda sisin-ku, ka polak, ka ku-suru satěrang tukang.” Dadi bĕling asu : „Me nja bale tau nan?" Dadi ia-bawa-mo ling sowai Miskin: „Ta nja bale!" Mutu ia-gita ling asu nan, ia-turit lampa nè, ia-tumpan-mo desa 
één zak gegeven, het is niet noodig mij eten te geven, want nu gaan wij naar boord, want de gezagvoerder is geheel alleen op het schip; indien de koopman het eens te weten mocht komen, zou hij boos zijn."

Toen gingen de matrozen aan boord, daarop zeide de gezagvoerder : „Nu ga ik aan wal, jongens!” Men bracht hem aan land en bracht een trommel naar zijn huis; aldaar aangekomen zeide hij tot de matrozen: „Gaat gij aan boord, ik zal later gaan.”.De vrouw van den gezagvoerder zeide: „Heeft de koopman u geen goud gegeven?” - „Ons heeft hij niets gegeven.” - „Dan moeten wij geduld hebben; als hij ons niets gegeven heeft, hebben wij geen geld."

Om kort te gaan, Miskin ging weer aan boord. Vroeg in den morgen maakte de vrouw van Miskin de trommel open en zag daarin één ring; niets anders was er in. $Z \mathrm{ij}$ deed dien ring aan haar vinger en nam, (nog) vroeg in den morgen, een bijl en ging hout hakken. De bijl werd van goud, het hout werd van goud.

De vrouw van Miskin bemerkte dat de ring aan haar vinger stuk was; dit deed haar leed. Zij bracht den ring naar een goudsmid. Toen sprak zij: „Kom, soldeer dezen ring, ik zal er u 30 rijksdaalders voor geven als loon.” De goudsmid sprak: „Ga maar naar huis, ik zal hem u later brengen." De vrouw van Miskin ging dan naar huis. De goudsmid nam een hamer; toen hij dien in de hand hield, werd hij van goud; hij nam een tang, ze werd van goud. Toen ging de goudsmid er van door met den ring.

Toen Miskin thuis kwam, vroeg hij aan zijne vrouw: „Waar is de ring gebleven?” - „Hij is gebroken, terwijl ik hout hakte, ik heb den goudsmid al bevolen hem te herstellen.” — „Ga naar den goudsmid zien, snel!" Men ging naar hem zien, maar hij was er reeds van door gegaan. De vrouw van Miskin was bedroefd. Toen sprak hij: „Het is onnoodig om er u zorgen over te maken; maak brij van kleefrijst, maak die zwart, geel en wit, rooster ongepelde rijst, en wat ook straks mag komen, schrik er niet van, want jk zal ze allen roepen."

Toen hij den hond riep, kwamen er zoovelen, dat zij 't erf vulden; toen hij de kat riep, vulden zij het erf; toen hij de rat riep, vulden zij het huis; toen hij de slang riep, vulden zij het erf. Miskin sprak: ,Ik ben in moeilijkheden, mijn ring is er niet meer, hij was gebroken, toen heb ik een goudsmid gelast hem te herstellen (maar hij is er mede van door gegaan)." De hond sprak: „Waar is het huis van dien man?” De vrouw van Miskin bracht hem er : ,Hier is het huis.” Toen de hond het gezien had, volgde hij de voetstappein en vond de 
pang tukang. Dadi běling-mo asu: „Laga tama, tikis, lalo ete sisin nan!” Dadi bĕling tikis: „Ada bodok bau aku!” Dadi běling bodok: „Aku timal, kĕna ada asu.” Bĕling asu: „Aku timal.” Dadi bĕling asu kĕbali : „Kĕna ada ular!” Bĕling ular : „Aku timal.”

Dadi tama tikis ko dalam bale, ia-buja sisin, ia-tumpan ling dalam těromol kenang mane, ia-pěrari ling tikis. Dadi běling asu: „Akubawa, apa aku ku-gantjang barari." Tu-ete lema ling boa, dapat-mo bale Miskin, ia-beang-mo sisin lako nja Miskin: „Ma-mo, těrima sisin-mu ta, ame kami tu-mule-mo!' Dadi běling-mo asu, bĕling-mo bodok, bĕling-mo tikis, bĕling-mo ular : ,Lamin ada susa-kĕlam, nawar puan, kělek kadji, kadji ada-mo."

\section{$\mathrm{V}$}

Ada sopo tau, ada anak Muhammad singin, no-so-da lin boat ${ }^{1}$ ), adu ajam bae-si. Bapa ia-suka ling datu. Tingka bĕling datu: Samate, lamin bĕling bapa Muhammad, no ia-samate, lok ia-bĕri bapa Muhammad ling datu.

Dadi, dapat sopo masa, ĕntek bapa Muhammad lako bale datu, mutu tunong datu. Ngĕruntung bapa Muhammad ling dalam katunong datu nan baripi ; tĕrěmpat datu, no ia-tumpan ka ipi. Dadi bĕling datu: ,,Sai tau ngĕruntung ita? Ku-těrĕmpat ling dalam mutu ku-baripi, laga buja ipi-ku; lamin no mu-tumpan pitu-ng-ano, ku-samate kau!"

Dadi mule bapa Muhammad ko bale, batěris tunong. Dadi bĕling sowai: „Ma mangan!” Dadi ia-samong ling sělaki: „No-mo kumangan, apa ku-kasusa; ka ku-ěntek ko bale datu, ka ku-ngĕruntung, těrĕmpat datu mutu tunong; dadi, baripi datu, no ia-tumpan ipi. Dadi bakětoan datu: „Sai ngěruntung ita ?” Dadi ia-samong ling tau pěno: „Bapa si Muhammad!” Dadi tempo aku pitu-ng-ano buja ipi ; lamin no ku-tumpan, samate aku ling datu. Nan nja bua no kumangan ta, apa ku-kĕmĕlas sai ia-tumpan ipi datu, lagi datu nongka ia-tumpan!"

1) Hs. buat, elders steeds boat. (P. V.) 
plaats waar de goudsmid was. De hond sprak: „Ga eens binnen, rat, en haal den ring!” De rat sprak: „Er is een kat, die mij zal vangen.” De kat sprak: „Ik zal haar vijand zijn, maar misschien is er een hond.” De hond zeide: „Ik zal zijn vijand zijn.” Wederom sprak de hond: „Misschien is er een slang.” De slang zeide: „Ik zal zijn vijand zijn."

Toen ging de rat het huis binnen en zocht den ring, vond dien in een trommel, die behoorde tot de uitrusting van den smid, en liep er snel mede weg. De hond zeide: „Ik zal hein brengen, want ik loop het snelst." Om kort te gaan, gekomen aan het huis van Miskin, gaf hij hem den ring: ,Welaan, neem uw ring aan, dan kunnen wij terugkeeren." De hond, alsook de kat, de rat en de slang zeiden : ,Als $\mathrm{u}$ in ongelegenheid zijt morgen of overmorgen, roep ons, wij zullen er zijn."

\section{V}

Er was eens een man, die een zoon had, Muhammad geheeten, die niets anders deed dan hanen laten vechten. De vader was in gunst bij den vorst. Als de vorst (omtrent iemand) zeide: Dood (hem), en indien de vader van Muhammad (daar tegen) sprak, werd die persoon niet gedood, zoo geliefd was hij bij den vorst.

Op zekeren tijd gebeurde het, dat de vader van Muhammad in de woning van den vorst kwam, terwijl deze sliep. Hij maakte gedruisch in de slaapkamer van den vorst, die juist drcomde; deze schrok wakker en kon niet vinden, wat hij gedroomd had. De vorst sprak: „Wie heeft zoo even gedruisch gemaakt? Ik ben midden in het droomen wakker geschrokken, gij moet mijn droom zoeken; indien gij die niet binnen 7 dagen vindt, zal ik u laten dooden."

De vader van Muhammad keerde naar huis terug, ging rechtstreeks naar zijn bed en legde zich daarop neer. Zijne vrouw sprak: ..Kom, eet!" Haar man antwoordde: „Ik eet niet, want ik ben in moeilijkheden; nadat ik was opgeklommen naar het huis van den vorst en gedruisch had veroorzaakt, schrok de vorst wakker uit zijn slaap: toen kon de vorst, die aan het droomen was, zijn droom niet vinden. Toen vroeg hij: ,Wie heeft dat gedruisch zoo even veroorzaakt?" Daarop antwoordden de omstanders: „De vader van Muhammad!” Toen gaf hij mij een termijn van 7 dagen om zijn droom te zoeken; als ik dien niet vind, laat de vorst mij dooden. Dat is de reden, dat ik nu niet eet, want ik kan mij niet begrijpen wie den droom van den vorst kan vinden, terwijl de vorst ze niet gevonden heeft!" 
Mule Muhammad bawa ajam; ěntek ko bale nangis eneng mè lako ina. Dadi běling ina: „E anak-e, na djina mu-nangis, apa bapamu susa, ia samate ling datu.” Dadi bĕling Muhammad: „Kuda bua ia samate bapa ling datu, apa ia-běri bapa-ku ling datu ?” — „Ada sala bapa-mu ko datu; datu mutu tunong, ěntek bapa-mu ngĕruntung, dadi těrěmpat datu; datu mutu baripi, no ia-tumpan ipi. Dadi běling datu: Laga buja ipi-ku, ka ku-těrĕmpat; ku-tempo kau pitu-ng-ano, lamin no mu-tumpan, ku-samate kau."

Bĕling Muhammad: „Laga sia-koat, bapa, sia-mangan, era mudi ku-buja ling aku; gampang, bapa-e, lalo eneng kěrtas lako datu ke mangsi, ame ku-buja ipi datu!" Lalo bapa balangan ko bale datu: „Ada mu-tumpan ipi-ku nan?” — „Ada-mo ku-tumpan, ia ku-eneng kěrtas ke mangsi, ia ku-surat ipi kalepe-kadji nan.” Dadi ia-beang-mo kěrtas ke mangsi, ia-bawa-mo mule ko bale. Bĕling Muhammad: „Ada sia-bawa, bapa, kěrtas ke mangsi nan ?” Bĕling bapa : „Ta nja!” - „Maeng ko ta, ame ku-surat!” Ia-beang-mo ling bapa kertas ke mangsi, ia-surat-mo ling Muhammad. Suda ia-surat: „Ma-mo bawa, bapa, beang ko datu, ta nja ipi datu."

Dadi bĕling datu: „Ada-ke mu-bawa?” Běling bapa Muhammad: „Ada-mo, ta nja!” Ja-beang-mo lako datu, ia-batja-mo ling datu surat nan: „Lalo kĕlek Muhammad, nja lampa tumpan ipi-ku!” Lalo iakĕlek ling tau: „E Muhammad, kĕlek kau datu!”- „No ku-roa, ia apa kělek aku ling datu? Apa ipi ka-mo ku-tumpan, masi kĕlek aku!" Mule-mo tau ka bakělek nan ia-bada datu: „No roa nja Muhammad datang, apa samong aku: Ka-mo ku-tumpan ipi datu, kělek-si aku, no ku-roa lalo.” Dadi bĕling bapa Muhammad nan: „Aku lalo kĕlek, nan-po roa datang."

Balangan bapa lalo kělek Muhammad, ada ia-dapat pang bale Muhammad. Bĕling bapa: „Te-mo tu-lalo, anak-e, apa kĕlek kau datu!” - „No ku-lalo, bapa-e, ma bawa surat ta, beang ko datu." Ia-bawa-mo ling bapa Muhammad surat nan, ia-beang ko datu. Ia-batja ling datu, kaměri datu ia-batja surat: „Lalo ete Muhammad, 
Muhammad kwam thuis met een haan; in huis gekomen, huilde hiij, zijn moeder om eten vragende. De moeder sprak: „Mijn kind, huil toch niet, want uw vader is in moeilijkheden, de vorst wil hem laten dooden.” Muhammad sprak: „Waarom wil de vorst vader laten dooden, hij is immers in gunst bij den vorst?” — „Uw vader heeft schuld jegens den vorst; terwijl deze sliep, besteeg uw vader zijne woning en maakte gedruisch, zoodat de vorst wakker schrok. Deze was juist aan het droomen en kon zijn droom niet terugvinden. De vorst zeide: Zoek mijn droom eens, want ik ben wakker geschrokken. Ik geef u 7 dagen tijd, als gij hem binnen dien tijd niet vindt, laat ik u dooden."

Muhammad sprak: „Kom, sta u maar op, vader, en ga u eten, ik zal later wel zoeken, het is gemakkelijk, vader, ga papier en inkt aan den vorst vragen, dan zal ik den droom van den vorst zoeken." De vader begaf zich op weg naar de woning van den vorst. „Hebt gij mijn droom gevonden?” — „Ik heb hem gevonden, ik wil om papier en inkt vragen, om dien droom van Uwe Majesteit op te schrijven." Men gaf hem papier en inkt en hij bracht die naar huis. Muhammad sprak: „Hebt gij papier en inkt medegebracht?" De vader sprak: „Hier is het.” — „Geef 't hier, dan ga ik schrijven!" De vader gaf papier en inkt en Muhammad ging aan 't schrijven. Toen hij gereed was (zeide hij): „Zie hier, neem dat, vader, en geef het aan den vorst, dit is de droom van den vorst."

De vorst sprak: „Hebt ge (mijn droom gevonden) en brengt ge hem?" De vader van Muhammad sprak: „Ik heb hem, zie hier!” Hij gaf den brief aan den vorst en deze las hem: „Gaat Muhammad roepen, hij toch heeft mijn droom gevonden!" Men ging hem roepen: .,Muhammad, de vorst laat u roepen!” — ,Ik wil niet, waartoe laat de vorst mij roepen? Zijn droom heb ik immers gevonden en toch laat hij mij roepen." De lieden, die gegaan waren om hem te ontbieden, keerden terug en zeiden tot den vorst: „Muhammad wil niet komen, hij toch antwoordle ons: ik heb den droom van den vorst gevonden; ontbiedt deze mij, dan wil ik niet gaan." Toen sprak de vader van Muhammad: „Ik zal hem gaan roepen, dan zal hij wel willen komen."

De vader van Muhammad begaf zich op weg om hem te roepen, hij vond hem in huis. De vader sprak: ,.Welaan, laat ons gaan. mijn zoon, want de vorst laat u ontbieden!" - ,Ik ga niet, vader, daar, breng dezen brief aan den vorst." De vader van Muhammad bracht den brief en gaf hem aan den vorst. De vorst las den brief en was 
tode, bawa djuli kenang isong, apa ku-basanak-sělaki ke Muhammad dunja aherat, nja tau tumpan sarea ipi-ku; umong adjak ko ta, lamin roa, isong!"

Dapat bale Muhammad: „Nan-si nja, Muhammad-e, suru kami datu datang ete kau, sa-bole-bole mu-lalo ano ta, ta nja djuli kamibawa kenang ia kami-isong kau." No roa nja Muhammad, ia-umong sa-umong ling tau bakělek: „Pědi kami Muhammad, te mu-lalo batěmong ke datu!" Dadi běling Muhammad: „Ia apa ku-lalo batěmong, kĕlek tau bae-mo boat ling datu!” — „Pĕdi kami, Muhammad, kami-kangompa-mo datang kělek kau suru kami ling datu!" Dadi ia-samong ling Muhammad: „Lamin mu-kangompa, no-mo datang; bada datu nan: Kĕme, ku-kangompa-mo ling kau kĕlek Muhammad, apa siong roa datang."

Mule-mo tau ka lalo bakělek nan, ia-bada datu: ,No roa datang Muhammad; ku-umong, no roa; dadi ta ling běling Muhammad: no ku-roa lalo.”. Běling bapa Muhammad : ,Aku-lalo kělek Muhammad!” Balangan bapa; dapat bale, ada Muhammad tokal. Bĕling bapa Muhammad: ,Te-mo tu-lalo, anak-e, pida kali-mo datu basuru, no mu-roa lalo; kěna tu-mali lako datu, anak-e!” — „Lamin nan-po ling-sia, tu-lalo-mo pĕri datu!"

Bĕling-mo bapa Muhammad: „E ina Muhammad, beang kĕre anak-mu ke kěpia, apa ia ku-bawa lalo pěri datu; to-mo pida kali basuru datu, nongka roa lalo anak-mu; dadi ku-bada anak-mu: kĕna tu-mali; ba to roa-mo lalo." Ia-beang-mo kěre ling ina. Lalo-mo pĕri clatu.

Dapat bale datu, bĕling-mo datu: „E Muhammad, kau lampa tumpan ipi-ku?” — „Kědjulin-tumpan ipi kalepe-kadji; ia kědjulin-eneng ko kalepe-kadji pina kapal pitu tiang ke pina kĕdjulin dulang ĕmpatpulu ĕmpat, ke tjangkir, ke piring, bulaeng sarea; pina kĕdjulin 
verheugd na het lezen: „Gaat Muhammad halen, jongens, neemt een draagstoel mede om hem te dragen, want ik ben in broederschap met hem in deze wereld en in de toekomstige, hij is de man, die alles gevonden heeft, wat ik gedroomd heb; noodigt hem met vleiende woorden om hier te komen, als hij wil, draagt hem!"

Toen zij bij Muhammad aan huis kwamen (zeiden zij): „Dat is de zaak, Muhammad, de vorst heeft ons gezonden u te komen halen, als gij eenigszins kunt ga dan thans, hier is een draagstoel, welke wij medegebracht hebben om u te dragen." Muhammad wilde niet; zij die gezonden waren om hem te roepen, zochten hem op allerlei wijze met vleiende woorden over te halen: „Heb medelijden met ons, Muhammad, kom, ga den vorst bezoeken!' Muhammad sprak: „Waartoe zal ik mij tot hem begeven, de vorst doet niets anders dan menschen roepen!”- „ ,Heb medelijden met ons, Muhammad, wij zijn vermoeid van het hierheen komen om $\mathrm{u}$ te ontbieden, naar de vorst ons heeft bevolen!” Muhammad antwoordde : „Als gij vermoeid zijt, gaat dan niet meer; zegt den vorst: Hoe, wij worden maar vermoeid door u om Muhammad te gaan roepen, want hij wil niet komen."

$\mathrm{Zij}$, die waren gaan roepen, gingen terug en berichtten den vorst: „Muhammad wil niet komen; wij hebben gepoogd hem met vleiende woorden over te halen, maar hij wil niet; hij blijft bij dit gezegde: ik wil niet gaan.” De vader van Muhammad zeide: „Ik ga Muhammad roepen!" Hij begaf zich op weg; toen hij aan 't huis gekomen was, was Muhammad daar gezeten. De vader sprak: „Laat ons gaan, mijn zoon, hoevele malen heeft de vorst al om u gezonden en wilt gij niet gaan; wij mochten ons eens bezondigen tegenover den vorst, mijn zoon!” - „Als u dat zegt, laten wij ons dan naar den vorst begeven!"

De vader van Muhammad sprak: ,Moeder van Muhammad, geef uwen zoon een kain en een muts, want ik wil hem medenemen om zijne opwachting bij den vorst te maken; de vorst heeft al verschillende malen om hem gezonden, maar uw zoon heeft niet willen gaan; toen zeide ik tot hem: 't zou kunnen zijn, dat wij ons bezondigden tegenover den vorst, en nu wil hij gaan." De moeder gaf hem een kain. $Z$ ij begaven zich naar den vorst.

Toen zij in de woning van den vorst gekomen waren, zeide deze: .,Muhammad, hebt gij dan gevonden, wat ik gedroomd heb?” - ..Uw dienaar heeft Uwer Majesteits droom gevonden; hij wenscht Uwe Majesteit te verzoeken een schip met zeven masten te laten maken en voor hem te laten vervaardigen 44 schenkbladen, met 
pabua ĕmpat-pulu ĕmpat, pabua bulaeng sarea; pina kĕdjulin tipar ěmpat-pulu ěmpat, bulaeng; pina kědjulin těpong bau sapulu pikil; angkit bulaeng olo ko kapal bau sa-těnga kojan, intan sa-těnga kojan ke buja kĕdjulin tau sama rea, sama panjang, sama rua idong-mata!"

Ia-buja-mo ling datu, ada-mo ia-tumpan tode ěmpat-pulu ěmpat. Ja-gita-mo ling Muhammad, ia-saturin-mo ko kapal tau ode sarea. Dadi běling-mo Muhammad: „Puan ia kědjulin-balajar.” Dadi běling datu: „Balong-si, Muhammad-e!”

Dadi, tu-ete lema, běling-mo datu: „Nawar turin ko kapal sarea nènè, tulong betak mangar nja Muhammad, apa sama ode-ode sarea!" Turin-mo sarea tau pĕno, ia-betak-mo mangar; dapat-mo mbao kapal mangar, turin sarea tau pěno ko darat, kapal Muhammad balajar-mo.

Datang angin ka ling ano siip, ia-sangangkang ano rawi kapal; datang angin ka ling ano rawi, ia-sangangkang ano siip. Dadi tělu-ngano bakĕliong kapal. Dapat ĕmpat ano, bĕling-mo Muhammad: „E tode, laga-mo satěrang tali lajar sarea, ame ruris-mo kapal ta barari lako Mĕnggěribi. Dadi balajar kapal sa-bulan, dua bulan.

Tu-ete lema, běling Muhammad: „E tode, lalo ĕntek ko bao tiang bau sa-tau, gita kapal pang dalam běrang Mĕnggěribi!” Dadi běling tau ode : „Sapěno bĕrang ling kapal, nonda ola tu-tama kita!” Bĕlingmo Muhammad: „Satěri mangar-kita dunung, ame lalo ěntek bau ĕmpat!” Ěntek tau ode ko bao sěkutji, ia-dajong-mo, ěntek ko darat.

Dapat darat, batěmong ke djuragan kapal pěno nan : ,,Me ka lis-kau, tau ode?” — „Ka kami-lis Mangkasar!” — ,Me ia lako-mu?” „Ia kami-datang ko Mĕnggěribi ta-si.” — „Apa ia (h)adjat mudatang ?” - „Ia kami-datang bakětoan lako datu Mĕnggěribi." „Kami to-mo dua-pulu tin, sarea kapal ta, kami-bakètoan lako datu Mĕnggĕribi ta, no-po-da samong kami, apa lagi kau tau ode, kapal-mu ode, ia-roa kau ling datu, kami, kapal api pitu tiang kapal-kami, no- 
kopjes en borden, alles van goud; voorts om voor $\mathrm{Uw}_{w}$ dienaar te laten maken 44 sirih-stellen, alle van goud; 44 vergulde matten; laat voor Uw dienaar meel maken, ongeveer 10 pikol's; laat goud aan boord brengen, ongeveer een halve kojan, diamanten ter hoeveelheicl van een halve kojan en laat voor mij zoeken jongens van dezelffe lichaamgestalte en van hetzelfde uiterlijk."

De vorst liet ze zoeken en vond zoo 44 knapen. Toen Muhammad ze gezien had, liet hij al de jongens naar het schip gaan. Toen zeide hij: „Overmorgen wil ik uitzeilen.” De vorst sprak: „Goed, Muhammad!"

Om kort te gaan, de vorst zeide toen: „Gaat gijlieden morgen allen aan boord en helpt Muhammad het anker op te halen, want allen op het schip zijn even klein!' De lieden gingen aan boord en trokken het anker op; nadat het boven op 't schip was, gingen zij weer aan land en zeilde het schip van Muhammad uit.

Als er wind kwam uit het Oosten, deed hij het schip met den voorsteven naar het Westen wenden; kwam de wind uit het Westen, dan deed hij 't naar het Oosten wenden. Gedurende 3 dagen ging het vaartuig in een kring rond. Op den vierden dag sprak Muhammad: ,Jongens, maakt de touwen der zeilen in orde, dan kan het schip snel voortgaan, rechtstreeks naar het Westerrijk." Toen voer het schip één maand, twee maanden.

Om kort te gaan, Muhammad sprak vervolgens: „Jongens, laat er eens een in de mast klimmen, om uit te kijken naar de schepen, welke liggen in (de monding van) de rivier van het Westerrijk!" Toen zeide de jongen (in de mast) : „De rivier is gevuld met schepen, er is geen weg voor ons om binnen te gaan." Muhammad sprak: „Laat eerst ons anker vallen en laten er een stuk of vier aan wal gaan." (Eenige) jongens gingen in de sloep, roeiden naar den wal en gingen aan land.

Aldaar ontmoetten zij de gezagvoerders der vele schepen; (deze vroegen) : „Van waar komt gij, jongens?”- „Wij zijn uit Makassar gekomen.” - „Waar wilt gij heen gaan?” - „Ons plan was het, hier in het Westerrijk te komen.” — „Wat komt gij hier doen?” - „Wij willen een huwelijksaanzoek komen doen bij den vorst van het Westerrijk.” - „Wat ons betreft, nu reeds twintig jaren lang, hebben wij, van al deze schepen, aanzoek gedaan bij den vorst van het Westerrijk, (maar) hij heeft ons nog niet geantwoord, hoe zoudt dan gij, die klein zijt, wier schip klein is, door den vorst gewild worden, terwijl wij, hoewel onze vaartuigen stoombooten zijn en 
po-ka samong kami ling datu! Runtung ano kami-ĕntek-mo bakětoan. nongka samong kami ling datu."

Dadi bĕling-mo tau ode: „No tu-tò rua kasuka Allah ta'ala, sai tò kami ia-roa ling datu?” - „Me ola ia mu-tama ko dalam bĕrang, rena kapal dalam běrang miliun nasa? Kau-balabu pang lit nan-mo, ia mu-tama ko dalam běrang, no-so-da ola-mu!" Dadi bĕling-mo tau ode nan: „Pang lit to-mo kami-balabu; ia kami-tama ko dalam běrang, no-so-da ola.” Dapat-mo ling pětang, běling Muhammad: „E tode, lalo tama ko dalam kamar sarea nènè, apa ada boat-ku mudi !" Tama tau ode sarea ko dalam kamar.

Lalo Muhammad lako muna, běling Muhammad: „Lamin aku karue bitara, ěntek kau mangar ko bao kapal!" Ěntek-mo mangar ko bao kapal. Ěntek ko bao kamar Muhammad; dapat mbao kamar, tokal: „Lamin aku karue bitara, njĕmpong kapal, ngibar kau lako anok djĕmbatang datu Mĕnggĕribi!" Dadi njĕmpong kapal ngibar lako anok djĕmbatang. Bĕling Muhammad: „E tode, ma-mo sarea nènè, ete tali, sat lako djěmbatang!" Ia-ete tali tau ode nan, ia-sat-mo ko djĕmbatang kapal.

Dadi siip djaga datang bone datu Mĕnggĕribi, bĕling bone datu Mĕnggĕribi: „Sai ka beang kau kuwasa, mu-lalo sat kapal pang djĕmbatang ta, rena pang kami-maning?" Bĕling Muhammad: „Nan-si bua kami-olo kapal ta pang anok djĕmbatang datu Mĕnggěribi, ia pang bakědek bone datu Mĕnggĕribi."

Turin-mo tau sowai nan sa-pitu ; ia-ĕnti ima ling tau ode mbao kapal nan, sa-pitu sama sopo ia-ĕnti ima. Ia-satokal mbao kadera, datang pitu ia-bawa tipar, ia-salěbar; datang pitu bawa pabua; datang pitu bawa dulang. Dadi no mongka mama, inim ai kawa no-so-ka, heran ia-gita tau ode nan, sama rea-rea, nonda tau rango sa-tau-tau.

Dadi bĕling-mo tau sowai nan: „Kami-ngamit-mo, djuragan-e!” Bĕling Muhammad: „Laga inim ai kawa dunung!” — „No-mo clunung," ling tau sowai nan, ,apa lè-mo kami ta, kěna buja tau ling 
zeven masten hebben, nog niet door den vorst geantwoord zijn? Elken dag gaan wij aan wal, om ons aanzoek te doen, maar de vorst heeft ons (nog) niet geantwoord."

Toen zeiden de knapen: „Wij weten niet wat de wil van Allah is, wie weet of wellicht de vorst ons niet wil hebben?” - „Langs welken weg wilt gij de rivier binnen komen, dewijl het aantal schepen in de rivier(monding) een millioen bedraagt? Gij moet maar ankeren daar in zee, om in de rivier te komen is er geen weg meer!" De knapen zeiden (tot Muhammad): „Nu zullen wij in zee moeten ankeren; om in de rivier te komen is er geen weg!" Toen het avond geworden was, zeide Muhammad: "Jongens, gaat allen in de kajuit, want ik heb daarna iets te doen." Allen gingen naar binnen.

Muhammad ging naar den voorsteven en sprak: „Als ik van goddelijke afkomst ben, kom gij anker dan op het schip!" Het anker kwam op het schip. Muhammad klom boven op de kajuit en ging daar zitten (en sprak): ,Als ik van goddelijke afkomst ben, spring dan op, gij schip, en vlieg tot ge komt te liggen aan den aanlegsteiger van den vorst van het Westerrijk." Toen sprong het schip op en vloog naar den aanlegsteiger. Muhammad sprak: ,Jongens, vooruit, komt allen naar buiten, neemt de touwen en bindt het schip aan den steiger!' Zij kregen de touwen en maakten het schip aan den steiger vast.

Toen de morgen aanbrak, kwamen hofdames van den vorst van het Westerrijk. Ze zeiden: ,Wie heeft u machtiging gegeven om uw schip aan dezen steiger vast te binden, dewijl dit de plaats is voor ons om te baden?” Muhammad zeide: „Juist daarom hebben wij het schip een plaats gegeven aan den steiger van den vorst van het Westerrijk, omdat dit de plaats zal zijn, waar de hofdames van den vorst zich zullen vermaken."

Alle zeven hofdames kwamen aan boord; zij werden bij de hand geleid door knapen op het schip, elk werd door één geleid. Nadat men haar op stoelen had doen plaats nemen, kwamen zeven knapen die matten droegen en die uitspreidden; er kwamen zeven, die sirihdoozen droegen; er kwamen zeven, die schenkbladen droegen. Zij (de hofdames) kauwden geen sirih, zij dronken ook geen koffie, uit verwondering bij het zien van die knapen, allen van dezelfde grootte, zonder dat er één volwassen mensch bij was.

Toen zeiden zij : „Wij vragen verlof on te vertrekken, gezagvoerder!” Muhamniad sprak: „Drinkt eerst koffie.” — „Neen”, zeiden de dames, ,want wij zijn lang uitgebleven, de vorst mocht eens naar 
datu.” Bĕling Muhammad: „Balong-si.” Bĕling Muhammad lako tau ode: „Lalo ete bulaeng dalam peta, beang sama sa-gantang!” Iabeang-mo ling tau ode nan.

Mule-mo bone lako bale datu, bawa-mo rungan: „Ada kapal pang anok djĕmbatang, ku-heran nonda tau rango sa-tau-tau, tau sama ode bae-si, ta nja bulaeng beang kami, sama sa-gantang kami.” — „Mudi kami-lalo kami!"' Lalo-mo siwa děngan.

Bĕling: „Kuda kĕlam-olo kapal pang anok djĕmbatang ta, apa pang kami-maning ?" Bĕling Muhammad: „Sangka kami-olo kapal ta pang anok djĕmbatang ta, ia pang bakĕdek bone datu Mĕnggĕribi."

Bëling-mo Muhammad: ,E tode, ĕnti ima tau sowai nan sama sopo nènè!' Satokal ko bao kadera, tau siwa ete tipar, ia-salěbar; datang siwa bawa pabua, datang siwa bawa dulang. Bĕling Muhammad: „Laga inim ai kawa!” Nongka ia-inim ai kawa nan, heran ia-gita tau ode serea, nonda tau rea sa-tau-tau.

Ngamit-mo: „E djuragan-e, ia kadji-mule-mo!” Ia-samong ling Muhammad: „Balong-si.” Bĕling Muhammad: „E tode, lalo ete bulaeng siwa gantang, beang sama sa-gantang!" Mule-mo bone.

Dapat bale datu, bĕling-mo ko ina-susu bidja datu Mĕnggĕribi lok balong tau ode nan mbao kapal nan sarea, nonda tau rango sa-tautau. Dapat nawar lalo-mo turin ina lala nan sapulu dĕngan. Bĕlingmo: „Sai ka beang kau kuwasa olo kapal pang anok djĕmbatang ta, rena pang kami-maning?” Bĕling Muhammad: „Bua kami-olo pang ninta, ia pang bakĕdek ina lala Mĕnggĕribi ta."

Ěntek-mo ina lala ko bao kapal, ia-ěnti ima ling Muhammad, ia-bawa tama ko dalam kamar; tau siwa tokal-mo pang bao kadera pang luar kamar. Datang tau siwa bawa tipar, ia-salěbar tipar; datang siwa bawa pabua, datang siwa bawa dulang. Bĕling Muhammad: „Sila-mo, inim ai kawa sarea.” Ia-samong-mo ling tau pang luar: „Ta-mo!” 
ons zoeken.” Muhammad sprak: „Goed (zooals gij wilt).” Hij zeide tot de knapen: „Haalt goud uit het scheepsruim en geeft aan ieder ter hoeveelheid van één gantang." De knapen gaven (haar het goud).

De hofdames keerden terug naar de woning van den vorst en brachten het bericht: „Er is een vaartuig gelegen aan den steiger, tot onze verwondering was er niet één volwassen mensch aan boord, al te maal knapen van dezelfde grootte; hier is goud, dat men ons gaf, ieder een gantang." - „Laten wij hierna gaan!” $Z_{i j}$ gingen met hun negenen.

Zij zeiden: „Waarom heeft $\mathfrak{u}$ het schip hier bij den steiger geplaatst, want liet is de plaats waar wij baden." Muhammad sprak: „Daarom hebben wij het schip hier doen liggen, omdlat het de plaats is waar de hofdames van den vorst van het Westerrijk zich zullen vermaken."

Hij zeide (verder) : ,Jongens, leidt ieder der vrouwen bij de hand.” Men liet haar zich zetten op stoelen, negen knapen haalden matten en spreidden die uit, negen kwamen beteldoozen brengen, negen kwamen met schenkbladen. Muhammad zeide: „Drinkt eens koffie!” $\mathrm{Zij}$ dronken geen koffie, uit verwondering bij het zien, dat het allen knapen waren en er geen enkele volwassene bij was.

Zij vroegen verlof heen te gaan: „Gezagvoerder, wij wenschen naar huis te gaan!" Muhammad antwoordde: „Goed.” Hij zeide (verder) : „Jongens, gaat negen gantang goud halen en geeft ieder één gantang." De hofdames gingen terug.

Toen zij in de woning van den vorst gekomen waren, zeiden zij tot de voedstermoeder van de dochter van den vorst van het Westerrijk, hoe mooi al die knapen op het schip waren, terwijl er geen volwassene aanwezig was. Den volgenden dag ging de voedstermoeder der prinses met negen volgelingen aan boord. Zij sprak: „Wie heeft $\mathrm{u}$ machtiging gegeven het schip bij den steiger te plaatsen, dewijl het de plaats is waar wij baden?” Muhammad zeide: „Daarom hebben wij 't daar een plaats gegeven, omdat het de plaats is, waar de voedstermoeder der prinses van het Westerrijk zich pleegt te vermaken."

Zij kwam op het schip, terwijl Muhammad haar bij de hand voerde en haar in de kajuit bracht; de negen (hofdames) zetten zich op stoelen buiten de kajuit. Er kwamen negen (knapen) die matten brachten en die uitspreidden, er kwamen negen met sirihdoozen, negen met schenkbladen. Muhammad sprak: „Als 't u belieft, drinkt wat koffie!" Zij die buiten waren antwoordden: „Dadelijk.”

D1. 92. 
Bĕling-no nja Muhammad ling dalam kamar lako ina lala nan. „Ada-ke bulong lala nan?” Dadi ia-samong ling ina lala nan: „Nonda bulong, baribu-ribu kapal datang bakětoan, nonda tau ka ia-samong ling datu.” Dadi běling Muhammad: „Kami ta, ia kami-datang bakětoan-si!" Ia-samong ling ina lala: „No-so-da sala tau bakětoan, apa siong ada tau ka ia-sangip ling datu sarea kapal pěno ana."

Tu-ete lema, mule-mo ina lala nan. Dapat bale datu, ia-kĕtoan ling datu: ,Me ka lako-mu rame?” Dadi ia-samong: „Ka sarungan kĕdjulin ling sarea ulin dewa ode ada kapal pang anok djĕmbatang, nonda tau rango sa-tau-tau, tau ode bae sarea; dadi nongka kĕdjulinnjadu, nan nja bua kědjulin-lalo, kědjulin-heran kědjulin-gita sarea, nonda tau rango, tau ode sarea, sama panjang, sama rua sarea." Bĕling-mo datu: „Ma lalo kĕlek sarea lante-mantěri ; ia ku-roa kĕtoan hal ka sama lalo ko bao kapal sarea nènè !"

Tu-ete lema, datang-mo sarea lante-mantěri, bĕling-mo datu: „Ada kapal pang anok djěmbatang ana, rungan lako aku, ma lalo gita!" Basuru-mo lante-mantěri : „E sarian, lalo gita kapal ana, kĕtoan me ka lis kapal ta!” Dadi ia-kětoan-mo ling sarian: „Nan-si lue rua ia pangkĕling-kĕdjulin?” Ia-samong-mo ling lante-mantěri : „Nan-si-lue; lalo-mo balangan!"

Balangan-mo sarian Rok, dapat kapal ana, běling sarian Rok: „Kapal ka lis me kapal ta, djuragan-e?” — „Kapal ka lis Mangkasar.” - „Apa ia kanatang kapal ta?” Ia-samong ling Muhammad: „Tudatang bakĕdek-kědek-si lako ta ; sate tu-gita desa Mĕnggěribi." Mule sarian Rok lako bale datu, ia-kĕtoan ling lante-mantĕri : „Apa rungan, sarian Rok; ka lalo sarian Rok ko kapal nan?" Dadi ia-samong ling sarian Rok: „Ka-mo ku-kětoan me ka lis kapal ta ; ka lis Mangkasar.”

Dadi bĕling-mo datu: „E sarea nènè, apa kenang ia tu-balas tau ta?” Dadi njamong sarea lante-mantĕri : ,Tu-balas ke uwang!” Dadi bĕling datu: „Pida uwang-kita sarea tau ode ta; ka lalo ko bao kapal ana, ia-beang bulaeng, ada-mo dua-pulu pikil!" Bĕling-mo datu lako mantěri : ,Anak-ku kenang ia ku-balas, kira ia ku-beang bulaeng, 
Muhammad zeide in de kajuit tot de voedstermoeder der prinses: „Heeft de prinses een verloofde?” De voedstermoeder antwoordde: „Zij heeft geen verloofde; duizenden zijn de vaartuigen, die gekomen zijn, om een huwelijksaanzoek te doen, maar er is niemand, dien de vorst geantwoord heeft.” Toen sprak Muhammad: „Wij ook komen om een huwelijksaanzoek te doen." De voedstermoeder antwoordde : „Het is geen misdaad om een aanzoek te doen, want aan niemand van de lieden op al die vaartuigen daar ginds heeft de vorst een belofte gedaan."

Om kort te gaan, de voedstermoeder der prinses keerde naar huis terug. Toen zij de woning van derı vorst bereikt had, vroeg deze: „Waar zijt gij met uw velen naar toe geweest?” $Z \mathrm{ij}$ antwoordde: „Aan Uwe dienares was bericht door de ondergeschikte slavinnen van Uwe Majesteit, dat er een schip aan den steiger ligt, waarop niet één volwassen persoon is, maar al te maal knapen. Uwe dienares geloofde dat nu niet, daarom is zij daarheen gegaan en zij stond verwonderd, toen zij allen zag, dat er geen volwassen persoon was, maar al te maal knapen van dezelfde grootte en hetzelfde uiterlijk." De vorst zeide: „Gaat de rijksgrooten roepen; ik wil hen vragen betreffende de zaak, dat gij allen op het schip zijt gegaan!"

Om kort te gaan, de rijksgrooten kwamen en de vorst zeide: „Er ligt een schip aan den steiger daar, naar mij bericht is, gaat er eens naar zien!” De rijksgrooten bevalen: „Bode, ga naar het schip daar zien en vraag waar het vandaan komt!” De bode vroeg: „Is dat alles wat uw dienaar te zeggen heeft?" De rijksgrooten antwoordden: „Dat is alles; begeef u maar op weg!"

Toen de bode Rok 't schip bereikt had, zeide hij : „Vanwaar komt dit schip, gezagvoerder?” - „Van Makassar!” - „Wat komt het schip hier doen?” Muhammad antwoordde: „Wij komen ons hier wat verpoozen; wij zijn verlangend om het Westerrijk te zien." De bode Rok keerde terug naar de woning van den vorst, en de rijksgrooten vroegen hem: „Wat voor nieuws is er, bode Rok; zijt gij naar het schip gegaan?” Deze antwoordde: „Ik heb gevraagd, waar het schip vandaan kwam; het komt van Makassar."

Toen sprak de vorst: ,Gij allen, waarmede zullen wij deze menschen begiftigen?” De rijksgrooten antwoordden: „Laten wij hun geld schenken!” De vorst sprak: „Hoeveel moet ons geld zijn voor deze knapen; toen men toch aan boord is gegaan, gaven zij goud, wel twintig pikol!” De vorst sprak (verder) tot de rijksgrooten: „Met mijne dorhter wil ik ze beloonen, (want) naar ik meen, zou ik ze 
bulaeng pĕno; ia ku-beang intan, intan pĕno; dadi anak-ku ia kubaang”. Bĕling-mo mantĕri: „Kasuka dewa!”

Ia-suru sarian Rok: „Lalo bada sarea djuragan kapal pĕno ana, suru ĕntek nawar, mutu barĕmin pang ninta, me tau ia-tělit ling anak-ku, nan nja ia sělaki."

Dadi barĕmin sarea, ěntek lako bale datu sarea djuragan kapal. Bue barĕmin sárea: ,Lalo-mo kĕlek Muhammad, suru ěntek!” Balangan-mo sarian lalo kĕlek Muhammad; rapangkenang-mo sarea sawi Muhammad; no monda sa-tau ia-bilin pang kapal, bue ĕntek sarea. Mutu ia.gita ling djuragan kapal pěno nan: „Ta nja ia nantu datu ta; ta nja ia nantu, tau ode ta; te-mo tu-mule ko kapal-kita!" Mule-mo sa-běla, ngěntang sa-bĕla. Tokal Muhammad, lis anak datu, ia-tělit : „Nan nja sĕlaki-ku.”

No mongka ngamit djuragan pĕno nan ia-bilin datu, mule sarea ko kapal, mupakat pang kapal sarea: „Maeng tu-adang, ame tusamate-mo, lamin ada mule ko desa!"

Tu-ete lema, běling-mo datu: „Laga-mo”, běling ko mantĕri, ,kětoan-mo Muhammad pětang apa ia-roa, ame tu-sanika!” Dadi běling Muhammad: „Siong-si aku ia pina ${ }^{1}$ ) sowai, datu-ku-po ka suru aku, apa aku ulin datu.” Dàdi bĕling datu: „Lamin ada-si tau lin, lalo-mo kělek, apa kěrana lěga tau bakětoan!" Dadi ia-samong ling Muhammad :',Balong-si, puan ia kĕdjulin-balajar.” Dadi bĕling datu: „Balong-si, ame lema mu-datang.”

Tu-ete lema, běling Muhammad lako sarea dĕngan: „Sĕntek bĕndera, apa nawar ia tu-balajar!" Dadi bĕling-mo Muhammad: „Pĕresa tali lajar-mu sarea.” Ia-pĕresa-mo sarea ling dĕngan, dadi ia-bada Muhammad: „Balong-si tali lajar ta.” Bĕling-mo Muhammad: „Suda-mo, lamin ka mu-pěresa, apa nĕngka pĕtang tu-balajarmo, tu-mule ko desa kita, tu-lalo ete datu-kita."

Mutu ia-gita bĕndera Muhammad ling kapal pĕno nan, isi mĕriam sarea: „Tu-adang ia-lis, na ada tau tunong nĕngka, ame tu-samate!”

1) voor ku-pina. (J. C. G. J.) 
goud geven, dan moet 't veel goud zijn; zoude ik ze edelsteenen geven, dan moeten het vele zijn; dus zal ik mijne dochter geven." De rijksgrooten zeiden: „Zooals het Uwe Majesteit belieft!”

Den bode Rok werd bevolen: „Ga en deel mede aan de gezagvoerders van al de vele schepen, dat zij morgen aan land komen, en terwijl zij hier verzameld zijn, zal hij, op wien door mijn dochter gewezen wordt, haar echtgenoot zijn."

Toen kwamen alle gezagvoerders bijeen en gingen op naar de woning van den vorst. Toen zij allen bijeen waren, (zeide de vorst) : „Ga Muhammad roepen en beveel hem op te gaan!” De bode ging Muhammad roepen; alle matrozen van Muhammad kleedden zich; niet één liet hij op het schip achter, allen gingen aan land. Toen de gezagvoerders der (andere) vele schepen hen zagen, (zeiden zij): „Deze zal de schoonzoon van den vorst worden; deze kleine gezagvoerder zal de schoonzoon zijn; welaan laten wij naar ons schip terugkeeren!" Een gedeelte keerde terug, een gedeelte bleef. Muhammad zette zich. Toen de dochter van den vorst uit het huis kwam, wees zij op hem: „Die zal mijn echtgenoot zijn.”

De vele gezagvoerders verlieten den vorst zonder afscheid te nemen en keerden naar boord terug en kwamen aldaar overeen: „Laat ons hem opwachten om hem te dooden, als hij naar zijn land terugkeert!"

Om kort te gaan, de vorst sprak: „Welaan”, zoo sprak hij tot de rijksgrooten, ,vraagt Muhammad wanneer hij wil, dat wij hem in het huwelijk verbinden!” Toen zeide Muhammad: „Niet ik kan 't zijn, die haar tot vrouw zal maken; mijn vorst heeft mij gezonden, want ik ben een onderdaan.” Toen zeide de vorst: „Als er nog een ander is, ga hem dan roepen, wegens de menigte van hen, die aanzoek zijn komen doen!” Muhammad antwoordde: „Goed, overmorgen zal ik uitzeilen.” De vorst sprak toen: „Goed, opdat gij spoedig terugkomt."

Om kort te gaan, Muhammad sprak tot zijne gezellen: „Haalt de vlag in top, want morgen zullen wij uitzeilen!" (Voorts) zeide hij: „Ziet de touwen der zeilen na!" De touwen werden nagezien door de gezellen en toen berichtten zij Muhammad: „De suwwen der zeilen zijn in orde.” Muhammad sprak: „Genoeg dan, als gij ze'onderzocht hebt, want van avond zullen wij uitzeilen en terugkeeren naar ons land om onzen vorst te halen."

Toen (de lieden op) de vele schepen de vlag van Muhammad zagen, laadden zij hunne kanonnen": „Laten wij hem opwachten, als hij uitvaart, laat er straks niemand slapen, opdat wij hem dooden!"' 
Bĕling Muhammad lako dĕngan sarea: „Laga-mo tama ko kamar sarea nènè, apa ia tu-balajar-mo!" Dadi tama sarea ko kamar. Bĕling-mo Muhammad: „Lamin aku karue bitara, ngibar kau kapal!” Ngibar kapal. Tu-ete lema, siip djaga, ia-gita ling kapal pěno, no monda kapal Muhammad; ia-těropong, no monda ia-gita. Běling-mo djuragan kapal pěno nan: „Tu-anti, beang datang, ame tu-tear!”

Tu-ete lema ling boa, balajar Muhammad; dapat desa, saběling měriam dua lusin. Basuru datu: „Kapal ka ling me kapal to; sai ka beang nja bebas, aku ku-běrata, ka lalo adi-ku nja Muhanmad lako Měnggěribi, tau nudja no monda dalam desa, tau nesek no monda, lok ku-kasusa, terria nja datang nĕba ko desa ta; lalo kĕtoan lema, sarian!"

Balangan-mo sarian; dapat kapal nja Muhammad, ia-kĕtoan: „Kapal ka lis me kapal ta; sai ka beang bebas, datu-kami bĕrata?” Ia-samong ling nja Muhammad: „Ia kuda bĕrata datu-kau, karing aku njaman ate-ku? Nongka mu-tò ke adat-kami tau dagang? Mutu untung dagang-kami, kami něba; adat-kami tau dagang. No monda ia lěga kěrante tau; ma bawa surat ta, beang ko datu!” Ngamit-mo sarian lako Muhammad: „Ta-mo kadji-mule, djuragan-e, kadji-beang ko datu surat ta."

Tu-ete lema, dapat-mo sarian datu ko bale datu, ia-kětoan-mo ling datu: „Apa rungan, sarian?” — „Dewa, rungan balong! ada surat ka beang kědjulin ling djuragan kapal.” Bĕling datu: „Me nja surat nan, sarian, maeng ku-gita!” Ia-beang surat nan ling nja sarian, iabeang ko datu. Mutu ia-batja ling datu surat nan: „Lalo kĕlek sarea mantěri!"

Tu-ete lema, barěmin sarea mantěri. Bĕling-mo datu: „Nan nja ku-saremin nènè, kapal ka nĕba to, kapal nja Muhammad lampa mule; laga sama lalo ete sarea nènè!’ Balangan-mo sarea tau pĕno nan lalo ete Muhammad ko ${ }^{1}$ ) kapal; ina tau ode barěmin-mo sarea ko bale datu.

1) ko ontbreekt in het hs. (P. V.) 
Muhammad sprak tot zijne gezellen: „Welaan, gaat in de kajuit, want wij zullen uitzeilen!" Zij gingen allen binnen. Muhammad sprak: „Als ik van goddelijke afkomst ben, vlieg dan op, gij schip!" Het schip vloog weg. Om kort te gaan, bij het aanbreken van den dag was het vaartuig van Muhammad, toen (de lieden op) de vele schepen er naar keken, er niet meer; hoewel zij er met de verrekijker naar keken, zagen zij het niet meer. De gezagvoerders der vele schepen spraken: „Laten wij hier wachten, laat hem terugkomen, dan zullen wij hem bestrijden."

Om kort te gaan, Muhammad zeilde uit; toen hij zijn land bereikte, liet hij twee dozijn kanonnen hun geluid doen hooren. De vorst beval: „Van waar komt dit schip nu; wie heeft 't vrijheid van handelen gegeven; (terwijl) ik in rouw ben, (omdat) mijn jongere broeder Muhammad naar het Westerrijk is gegaan, (zoodat) er niemand is die (rijst) stampt in het land, niemand die weeft, zoo groot is mijn smart daarover, komt het plotseling in het land en lost kanonschoten; ga snel navraag doen, bode!"'

De bode begaf zich op weg; bij het schip van Muhammad gekomen, vroeg hij: „Van waar komt dit schip; wie heeft u vrijheid van handelen gegeven, (terwijl) onze vorst rouwt?" Muhammad antwoordde: „Wat komt het er op aan of uw vorst rouwt, als ik mij in mijn schik gevoel? Weet gij niet hoe het bij ons kooplieden gewoonte is? Als wij winst met onze waren gemaakt hebben, geven wij kanonschoten; dat is gewoonte bij ons kooplieden. Er is niets waarover wij veel te praten hebben; welaan, neem dezen brief mede en geef hem aan den vorst." De bode verzocht aan Muhammad verlof heen te gaan. „Ik ga nu terug gezagvoerder, ik zal dezen brief aan den vorst geven."

Om kort te gaan, toen de bode van den vorst diens woning bereikt had, vroeg de vorst: „Wat voor nieuws, bode?” - „Majesteit, goed nieuws! er is een brief mij door den gezagvoerder van het schip gegeven.” De vorst sprak: „Waar is die brief, kom, laat hem :nii zien!" De bode gaf den brief aan den vorst. Toen hij dien gelezen had, zeide hij: „Ga de rijksgrooten roepen!”

Om kort te gaan, de rijksgrooten kwamen bijeen. De vorst zeide: „Ik heb $\mathrm{u}$ daarom bijeen laten komen, het schip, dat kanonschoten gelost heeft, is het schip van Muhammad, die werkelijk teruggekeerd is; gaat hem allen afhalen!" De geheele menigte begaf zich op weg naar het schip om Muhammad af te halen; de moeders der knapen verzamelden zich in de woning van den vorst. 
Tu-ete lema, ěntek-mo nja Muhammad sarea dĕngan; dapat bale datu, ia-kong ling datu: „Kau lampa Muhammad, dapat-mo rua ling rasate-kaku, ku-basanak-sĕlaki ke kau dunia aherat! Ba ta me-mo waja ia mu-roa ling kau?” Dadi ia-samong ling Muhammad: „Sila, pina kapal pitu tiang ke momat bulaeng bau dua kojan, intan dua kojan ke dulang dua-pulu ke pabua dua-pulu, tipar dua-pulu!’ Ia-pina ling datu, dadi sa-ng-ano sarea.

Bĕling-mo nja Muhammad: „E tode sarea nènè, laga-mo; me nja ina-nènè, laga-mo ěnti ima!” Bĕling-mo tau ode nan: „No kadji-tò rua ina-kadji, djuragan-e!” Koat nja Muhammad, ia-ĕnti ima sopo: „Ta nja ina-kau”; ia-ete ade sopo ampo: „Ta nja ina-kau!” Tu-ete lema, bue-mo ia-sangĕnti ima ko ina sarea, nan-po ia-tò-mo rua anak sa-tau-tau. Běling-mo nja Muhammad: „E tode-e, ka-mo batĕmong ke ina-mu sarea nènè, lalo-mo turin ko kapal, puan ia tu-balajar, tubawa datu-kita lako Mĕnggĕribi!"

Tu-ete lema, běling-mo sarea tau ode nan lako ina: „Maeng-mo tu-basělaman, apa to-mo suru aku djuragan turin ko kapal sarea kami; sia-eneng kami doa pětang ano, kĕna kami-sĕlamat, tu-bau batěmong ke sia kěbali!"

Tu-ete lema, turin datu ko kapal; dapat mbao kapal datu: ,Kĕlek Muhammad, tode, salako ta, apa ia ku-kětoan!" Ia-lalo-mo kĕlek ling tau ode Muhammad. Bĕling-mo tau ode nan: „Ka suru kadji datu, djuragan-e, kĕlek kĕlam ko bao kapal datu." Tu-ete lema, balanganmo nja Muhammad, ĕntek ko bao kapal datu. Bĕling-mo datu: ..Nan-si nja ku-kĕlek kau, adi-e, pidan ia tu-balajar?” Ia-samong-mo ling nja Muhammad: „Nawar rawi hĕmis tu-balajar.” Ia-samong-mo ling datu: „Balong-si, adi-e, siong ada tau lin ia bĕling, malainkan kau mesa bae-si."

Dadi, tu-ete lema, balajar pang pětang hĕmis. Dadi ling dalam palajar tĕlu bulan. Tu-ete lema, dapat ling pětang, běling Muhammad: ..E tode, nawar siip-djaga, ěntek ko bao tiang, gita kapal ling dalam běrang ana masi-ke pĕno!" Ěntek ko bao tiang tau ode nan. Bĕling-mo tau ode nan: „Masi pěno kapal ling dalam bĕrang ana.” Dadi bĕling nja Muhammad: „Na-mo tu-sabarari kapal ta, kěna ia-gita tau ling 
Om kort te gaan, Muhammad ging aan land met al zijne gezellen; toen hij in de woning van den vorst gekomen was, omhelsde deze hem, (en sprak) :,,Gij zijt 't dan werkelijk, Muhammad, ik krijg gelijk ik het wenschte, wij zijn broeders hier op aarde en hiernamaals! $\mathrm{Nu}$, wanneer wilt gij (weder vertrekken) ?" Muhammad antwoordde : „Laat, als 't u belieft, een schip met 7 masten maken en bevracht het met goud, ongeveer 2 kojan, met 2 kojan edelsteenen en (laat maken) 20 schenkbladen, 20 sirihdoozen en 20 matten!" De vorst liet ze maken, in één dag was 't gereed.

Muhammad sprak: ,Jongens, gij allen vooruit; wie uwe moeder is, neemt haar bij de hand!” De knapen zeiden: „Ik weet niet (meer), hoe mijne moeder er uit ziet, gezagvoerder!" Muhammad stond op, hij nam er een bij de hand en zeide: „Dit is je moeder,” hij nam wederom een anderen bij de hand: „Dit is je moeder!” Om kort te gaan, nadat hij ze allen de hand hunner moeders had doen vatten, toen eerst herkende ieder haar kind. Muhammad sprak: „Jongens, nu gij allen uwe moeders ontmoet hebt, gaat nu (weer) aan boord, overmorgen zullen wij uitzeilen en onzen vorst naar het Westerrijk brengen."

Om kort te gaan, al de knapen zeiden tot hunne moeders: „Welaan, laten wij elkander de hand geven, want thans heeft de gezagvoerder ons allen bevolen aan boord te gaan; bidt gij voor ons dag en nacht, dat het ons welga en wij u kunnen weerzien!"

Om kort te gaan, de vorst ging aan boord; aldaar gekomen (zeide hij) : „Roept Muhammad, jongens, doet hem hier komen, want ik wil hem iets vragen!" De jongens gingen Muhammad roepen. Zij zeiden : „De vorst heeft ons gezonden, om u op zijn schip te roepen!” Om kort te gaan, Muhammad begaf zich op weg en ging aan boord. De vorst sprak: „Daarom heb ik u laten roepen, broeder, wanneer zullen wij uitzeilen?” Muhammad antwoordde: „Morgen in den namiddag vóór Donderdag zeilen wij uit.” De vorst sprak: „Goed, broeder, er is niemand anders, die er iets over te zeggen heeft, behalve gij alleen."

Toen, om kort te gaan, zeilden zij uit op Donderdag nacht. Drie maanden waren zij in de vaart. Om kort te gaan, op een avond zeicle Muhammad: ,Jongens, klimt morgen vroeg in de mast en ziet uit naar de vaartuigen in de rivier daar, of zij nog in grooten getale aanwezig zijn!” Er klommen jongens in de mast. Zij zeiden: „De schepen in de rivier zijn nog vele.” Toen sprak Muhammad: ,.Laten wij het vaartuig niet snel doen varen, wij mochten eens 
kapal pěno dalam běrang ana, tear tau era!’ Dadi ia-satingi lajar sarea, no mongka barari kapal.

Dapat ling pětang, ěntek Muhammad ko bao kapal pang datu. Běling-mo Muhammad: „Laga tama ko dalam kamar sarea tau ling dalam kapal ta!" Bue ia-satama ling Muhammad ko dalam kamar. Turin-mo Muhammad kěbali, ěntek ko bao kapal-nja, ia-sasai kapal nan sa-dua. Bĕling Muhammad lako sarea tau ode ling bao kapal-nja: „Laga sama tama dalam kamar sarea nènè!” Ka ia-satama sarea ko dalam kamar, ia-tali kapal sa-dua, suda ia-tali kapal nan, bẹling Muhammad: „Lamin aku karue bitara, ngibar kau kapal sa-dua!” Dadi ngibar kapal nan, olo diri pang anok djĕmbatang datu Měnggěribi.

Sĕlis-mo sarea tau ode ka ling kamar, bĕling-mo nja Muhammad: ,E tode, laga tali kapal-kita sarapat ko djĕmbatang ta, ame kapal datu tu-olo ko satue kapal-kita satěgo; lamin ka-mo mu-sat, datang bada aku, ame ku-lalo pěri datu!" Dadi ia-samong ling tau ode nan: „Bue ka kadji-sat, djuragan-e!” - „Sama tědu nènè, ta ia ku-lalo pěri datu, ia ku-sĕlis ling dalam kamar sarea tau ana!" Lalo nja Muhammad ĕntek, ia-uleng lawang kamar datu, ia-sĕlis-mo sarea tau pěno.

Bĕling-mo datu: „E adi Muhammad-e, apa-po pang-kita ta?” Dadi ia-samong ling nja Muhammad: „Ka kědjulin-sat kapal ta, dewa, ke djĕmbatang datu Mĕnggĕribi.” — „Pidan ka tu-dapat-pe, adi? Djina tu-dapat Mĕnggěribi balalo, lok gantjang! Kau ta-mo lampa mu-pědi aku, sadi běnar mu-basanak-sělaki ke aku dunia aherat! Ling-kau, adi-e, djěmbatang datu Měnggěribi; ku-rasate gita to.” Bĕling Muhammad: ,,Sila-mo!”

Ia-ĕnti ima datu. Ia-gito-mo djĕmbatang nan ling datu. Bĕling-mo nja Muhammad: „Ta nja, djěmbatang ta pang maning sarea bone datu Mĕnggĕribi.” Dadi bĕling-mo datu: „Nawar siip tu-gita-mo lampa bone datu datang maning ko djěmbatang to?" Dadi ia-samongmo ling Muhammad: „Siip-djaga ada-mo datang; lamin suka kalepekadji, sila tokal pang kamar!"

Tu-ete lema, dapat-mo ling siip-djaga, datang-mo bone datu; bakětoan bone datu nan: „Kapal ka lis me rua kapal ta, olo diri 
gezien worden door (de lieden op) die vele schepen in de rivier en dan zouden zij ons bestrijden!" Toen reefden zij de zeilen en het vaartuig ging niet meer snel.

Toen de avond gevallen was, ging Muhammad op 't schip, waar de vorst was. Hij zeide: „Gaat allen op dit schip in de kajuit!” Allen liet hij binnengaan. Toen ging hij weder van boord en ging op zijn eigen schip en deed de beide schepen bij elkander komen. Toen zeide hij aan alle knapen op zijn schip: „Gaat allen in de kajuit!" Nadat hij ze er allen in had doen gaan, bond hij de beide schepen aan elkander vast, daarna zeide hij: „Als ik van goddelijke afkomst ben, vliegt dan op, gij beide schepen!" Toen vlogen de schepen op en plaatsten zich zelf aan den steiger van den vorst van het Westerrijk.

Hij deed alle knapen uit de kajuit komen en zeide: „Bindt ons schip vlak aan den steiger vast en plaatst het schip van den vorst stevig vastgebonden aan de andere zijde van ons vaartuig; als gij ze gebonden hebt, komt het dan mij zeggen, dan ga ik mijne opwachting maken bij den vorst!” De knapen antwoordden: „Wij hebben ze vastgebonden, gezagvoerder!” - „Weest stil, thans wil ik mij tot den vorst begeven en de lieden daar uit de kajuit laten gaan." Muhammad ging naar het schip, opende de deur van de kajuit van den vorst en deed de lieden naar buiten komen.

De vorst zeide : ,Broeder Muhammad, waar zijn wij nu?” Muhammad antwoordde: „Ik heb het schip vastgebonden, Majesteit, aan den steiger van den vorst van het Westerrijk.” — „Wanneer zijn wij aangekomen, broeder? Wij hebben het Westerrijk toch in een oogenblik bereikt, zoo snel is het gegaan. Gij houdt toch werkelijk veel van mij, geheel in waarheid zijn gij en ik broeders in deze wereld en in het hiernamaals. Gij zegt, broeder, dat hier de steiger van den vorst van het Westerrijk is; ik verlang dien thans te zien." Muhammad sprak: „Als 't u belieft.”

Hij nam den vorst bij de hand. De vorst bezag toen dien steiger. Muhammad sprak: „Hier, deze steiger is de plaats, waar de hofdames van den vorst van het Westerrijk zich baden.” De vorst zeide : „Zullen wij werkelijk morgen ochtend de hofdames van den vorst zien, als zij naar den steiger komen om te baden?" Muhammad zeide: „Vroeg in den ochtend komen zij; als Uwe Majesteit het goed vindt, neem U dan, als 't U belieft, plaats in de kajuit!"

Om kort te gaan, toen de ochtend aanbrak, kwamen de hofdames van den vorst. $\mathrm{Zij}$ vroegen: „Van waar komt toch dit schip, dat zich 
pang anok djĕmbatang ta?” Ia-samong-mo ling Muhammad: „Sangka olo diri kapal ta pang anok djĕmbatang datu Měnggěribi, ia pang bakědek bone datu Mĕnggĕribi.” Bĕling-mo bone nan: „Tu-bau rua ĕntek ko bao kapal nan?” Bĕling-mo nja Muhammad: „Sila-mo ěntek, bua olo diri kapal ta, ia pang bakědek bone-si!"

Ia-rik sisi kapal nan ling bone nan; ia-ěnti ima ling tau ode ling bao kapal sama sopo; ia-angkat-mo kadera pitu, ia-satokal-mo ling bao kadera. Datang-mo pitu bawa tipar, ia-salěbar; datang-mo bawa pabua pitu; datang bawa dulang pitu. Ia-panto katěman tau ode nan ling datu ling dalam kamar. Bĕling-mo nja Muhammad: „Sila inim ai kawa!" Mama no-so-ka, inim ai kawa no-so-ka, ngamit-mo basělaman ko Muhammad.

Bĕling-mo nja Muhammad: „Lalo tama basělaman ko dalam kamar ana." Bĕru ia-uleng lawang kamar, ia-gita ada datu ling dalam kamar. Tama sa-pitu bone ko dalam kamar ia-idok nè datu, ngamitmo lako datu ia-mule bone nan. Bĕling-mo nja Muhammad: „E tode, tama ko peta ana, ete bulaeng, beang sama sa-gantang!" Dadi iapojong-mo bulaeng nan ke sĕlendang, mule-mo bone sa-pitu, batĕris tama ko bilik datu-dara, bĕling-mo bone nan lako ina-susu datu: „,Ka-mo ku-basĕlaman ita ke datu.” Dadi ina datu-dara ia-lalo-mo bawa lako rĕpan datu ling bone nan sarea.

Bĕling-mo datu: „Nja-ke kapal djuragan Muhammad?” — Nja, dewa, ka kĕdjulin-basĕlaman ita.”- „Kĕme, lamin siong?”- —Lamin siong, dewa, samate kĕdjulin!” Basuru-mo datu : „Kĕlek sarian Rok!” - „E sarian Rok, ma lalo gita djuragan kapal Muhammad ana; apa bada aku ling bone: adla kapal djuragan Muhammad; dadi ku-běling aku: kĕme lamin siong? Samong aku ling nja: lamin siong, dewa, samate kĕdjulin!"

Tu-ete lema, balangan sarian Rok, ia-lalo gita kapal nan. Mutu dapat djĕmbatang sarian Rok, barari djuragan Muhammad lako 
geplaatst heeft aan dezen steiger?" Muhammad antwoordde: „Daarom heeft het schip zich geplaatst aan den steiger van den vorst van het Westerrijk, omdat het de plaats is waar de hofdames van dien vorst zich vermaken.” De hofdames spraken: „Mogen wij soms op het schip komen?” Muhammad zeide: „Als 't u belieft, komt boven, daarom heeft het schip zich hier geplaatst, omdat het de plaats is, waar de hofdames zich vermaken!"

De hofdames betraden de zijde van het schip; knapen van boven op het schip namen ieder van haar bij de hand; zij brachten zeven stoelen en deden haar zich daarop zetten. Er kwamen zeven (knapen), die matten brachten en die uitspreidden; er kwamen (wederom) zeven, die sirihdoozen droegen, zeven, die schenkbladen droegen. De vorst keek van uit de kajuit naar wat de knapen verrichtten. Muhammad zeide: „Als 't $u$ belieft, drinkt koffie." Zonder sirih te kauwen of koffie te drinken, namen de dames afscheid, terwijl zij Muhammad de hand gaven.

Muhammad sprak: „Ga binnen daar in de kajuit, en geef (hem, die daarin is) een hand!" Zoodra de deur van de kajuit geopend was, zagen zij dat zich daarin een vorst bevond. De zeven hofdames traden binnen en kusten de voeten van den vorst en verzochten hem toen verlof om naar huis te gaan. Muhammad zeide: „Jongens, gaat in 't ruim, haalt goud en geeft ieder één gantang!' Toen, nadat zij het goud in hare slendang's gewikkeld hadden, gingen de zeven hofdames naar huis en begaven zich rechtstreeks naar het vertrek der prinses. $\mathrm{Zij}$ zeiden tot de voedstermoeder der prinses: „Gezagvoerder Muhammad is teruggekeerd met zijn vorst ${ }^{1}$ ), ik heb den vorst reeds de hand gegeven." Toen ging de voedstermoeder der prinses heen en bracht voor den vorst, wat de hofdames gezegd hadden.

De vorst sprak: „Is het 't schip van gezagvoerder Muhammad?” - „Het is het, Majesteit, Uwe dienaressen hebben hem zooeven begroet." - „Hoe, als 't niet het schip is ?” - „Als het 't niet is, Majesteit, dood dan Uwe dienaressen.” De vorst beval: „Ontbied bode Rok!” - „Bode Rok, ga zien naar het schip van gezagvoerder Muhammad, daar ginds, want de hofdames hebben mij bericht, dat het schip van gezagvoerder Muhammad er is; toen zeide ik: hoe, als hij 't niet is; waarop zij antwoordden: als hij 't niet is, Majesteit, dood dan Uwe dienaressen!"

Om kort te gaan, bode Rok begaf zich op weg, om het schip te gaan zien. Toen hij den steiger bereikte, snelde gezagvoerder Muham-

1) Deze zinsnede ontbreekt in den tekst. (P. V.) 
djěmbatang: „Ma lema, sarian Rok!” Bĕling-mo sarian Rok: „E nanta djuragan Muhammad, sĕlaniat ada datang!” Ia-ěnti ima sarian Rok ling djuragan Muhammad, ia-bawa batĕris ko dalam kamar. Mutu dapat dalam kamar sarian Rok, ia-gita datu tokal mbao kadera; sudjid sarian Rok, ia-sěma datu, ia-idok nè datu. Bĕling-mo sarian Rok: „Sělamat, dewa!” Ia-samong-mo ling datu: „Apa-mo rungan datu ta, sarian Rok?” Samong-mo ling sarian Rok: „Sĕlamat, dewa, no-so-da apa-apa."

Bĕling djuragan Muhammad: „E tode, ete sarian Rok, bawa tokal ko kadera!' Ia-angkang-mo ling tode, ia-sorong pabua sarian Rok. Bĕling-mo Muhammad: „Sila, mama nè sarian!” Ia-samong ling Rok: „Ta-mo, djuragan-e, kadji-mama!” No-so-ka mama sarian Rok, apa no ia-těngan, apa pabua bulaeng. Ia-sorong dulang kawa. Bĕling Muhammad: ,.Sila, inim ai kawa, sarian, nan rua ling datu, nè sarian-e!” Dadi njamong sarian Rok: „Ta-mo!" No-so-ka inim ai kawa sarian Rok, apa ia-gita dulang bulaeng; ngamit-mo sarian Rok lako djuragan Muhammad. Dadi ia-samong ling djuragan Muhammad: „Balong-si, nè sarian-e!” Bĕling-mo djuragan Muhammad: „E tode, ete bulaeng bau sa-gantang, intan bau sa-gantang, beang sarian Rok, apa ia mule-mo!"

Tu-ete lema, mule sarian Rok; dapat-mo bale datu Mĕnggĕribi, ramanik-mo datu: ,Apa rungan, sarian Rok, nja-si-ke kapal djuragan Muhammad?” Dadi ia-samong-mo ling sariàn Rok: ,Nja-si.” „Ada-ke tau lin rua ia-gita ling sarian Rok pang bao kapal ana?” Dadi ia-samong-mo ling sarian Rok: „Ada, dewa, tokal ling bao kadera ling dalam kamar; bawa kĕdjulin tama ling djuragan Muhammad. Mutu kĕdjulin-gita, kĕdjulin-kamĕlas, kědjulin-sudjid, dewa, kědjulin-sěma, karing kědjulin-idok nè; balong datu ana, dewa; tı-sěpan balong djuragan Muhammad, ngere balong datu ana!"

Ramanik-mo datu lako sarian Rok: „E sarian Rok-e, nan nja datu ka ia-gita ling sarian Rok nan, nan nja děngan ia ku-sukat papu sarian Rok.” Dadi běling-mo sarian Rok: „Batěpang balong, dewa, tu-sukat ke bidja dewa tau balong měnan; apa kanatang dunung 
mad er heen (en sprak): „Vooruit, snel, bode Rok!” Deze zeide: „Mijn beste gezagvoerder Muhammad, wees welkom bij uwe komst!” De gezagvoerder Muhammad nam hem bij de hand en bracht hem rechtstreeks naar de kajuit. Toen hij die betrad, zag hij een vorst daar op een stoel zitten; hij wierp zich voor hem ter aarde, maakte een sěmbah voor hem en kuste zijne voeten. De bode Rok sprak: „Heil zij U, Majesteit!” De vorst antwoordde: „Wat is er te melden omtrent den vorst hier, bode Rok?” Deze antwoordde: „Hij is wel, Majesteit, hem deert niets."

De gezagvoerder Muhammad sprak: „Jongens, leidt bode Rok en doet hem op een stoel zitten." De knapen gingen voor den bode zitten en schoven hem de sirihdoos toe. Muhammad sprak: „Als 't u belieft, kauw wat sirih, heer bode!” Deze antwoordde: „Aanstonds, gezagvoerder, zal ik sirih kauwen." Hij kauwde evenwel geen sirih, hij durfde niet, omdat het een gouden sirihdoos was. Men schoof hem toe een schenkblad, waarop de koffie stond. Muhammad sprak: „Als 't u belieft, drink wat koffie, bode, dat is de bedoeling van den vorst, bode.” Deze antwoordde : „Aanstonds.” Hij dronk echter geen koffie, omdat hij het gouden schenkblad zag, maar vroeg aan den gezagvoerder Muhammad verlof om heen te gaan. Deze zeide: „Goed, heer bode!" Toen sprak de gezagvoerder Muhammad: „Jongens, haalt goud, ongeveer ter hoeveelheid van één gantang, edelsteenen, ongeveer één gantang en geeft dat aan bode Rok, want hij wil naar huis terugkeeren!"

Om kort te gaan, de bode Rok keerde terug; toen hij in de woning van den vorst van het Westerrijk kwam, zeide deze: „Wat voor nieuws, bode Rok, is 't het schip van gezagvoerder Muhammad ?" De bode Rok antwoordde : „Het is 't.”- —,Hebt gij ook een ander persoon op het schip gezien?” Toen antwoordde de bode Rok: „Ja, Majesteit, hij zat op een stoel in de kajuit; gezagvoerder Muhammad deed Uw dienaar binnenkomen. Toen $\mathrm{Uw}_{\mathrm{w}}$ dienaar hem zag, ontstelde hij, hij wierp zich ter aarde, Majesteit, en maakte een sěmbah, daarop gaf ik den voetkus; schoon is die vorst daarginds, Majesteit; wij noemen den gezagvoerder Muhammad schoon, schooner nog is die vorst!"

De vorst (van het Westerrijk) sprak tot den bode Rok: „Bode Rok, die vorst, welken gij gezien hebt, die is 't met wien ik uwe kleindochter (mijne dochter, de prinses) wil laten huwen." Toen sprak bode Rok: „Het past uitstekend, Majesteit, dat een zoo schoon man in 't huwelijk vereenigd wordt met uwe vorstelijke telg, want de oorzaak van de vroegere komst van gezagvoerder Muhammad, 
djuragan Muhammad, gawe ia-ke nja, apa ada tau lin ka suru djuragan Muhammad lampa!"

,Ia tu-balas ke uwang pĕno, bulaeng pěno, intan pĕno; dadi ka ku-satěpang ke papu sarian Rok."

„Bĕnar, dewa, lok ka rua manik rĕpan.”

„Dadi nawar, sarian Rok, sarĕmin sarea lante-mantĕri, ame tu-bada ada djuragan Muhammad ka dapat!"

Tu-ete lema, balangan sarian Rok lalo kĕlek sarea lante-mantĕri. Dapat nawar siip-djaga, ada datang sarea lante-mantĕri, tokal ling rĕpan datu. Bĕling-mo datu: „Laga-mo sarěmin tuan imam, tuan kadi, apa to djuragan Muhammad ada-mo, ame puan tu-barĕmin-mo pang ninta kěbali, apa patit ia tu-rapulong patit lema-ke atawa lè-ke; kĕle tu-rasate lema, lamin no tu-dapat, dadi ia tu-kangila-si, kerrana datu luar desa, siong sopo desa ke kita rua; ame me-mé lok tu-parenta, ta tau luar desa, ada-ke lok ia no ke riri tu-boat, (na) kĕna tukangila; roa tu-kĕlek djuragan Muhammad dunung, ame tu-kĕtoan lok riri desa-nja."

Tu-ete lema, nawar siip, ia-suru lalo sarian Rok, lalo kĕlek djuragan Muhammad. Balangan-mo sarian Rok lalo dapat djĕmbatang. Ia-gita ling djuragan Muhammad, barari djuragan Muhammad, iaěnti ima sarian Rok: „Ma lema sarian Rok!” Ia-ĕnti ima, ia-bawa ko dalam kapal. Bĕling-mo djuragan Muhammad: „Te-mo tu-tama ko dalam kamar!” Bĕling-mo sarian Rok: „Ada datu ling dalam kamar ana?” Bĕling djuragan Muhammad: „No-so-da, sarian Rok-e; te-mo tu-tama ko dalam kamar!" Balangang-mo tama. Dapat dalam kamar, ia-satokal sarian Rok ko bao kadera.

Tu-ete lema, bĕling-mo sarian Rok: „Nan-si nja kanatang-kadji, kadji-datang pasila djuragan Muhammad.” Bĕling-mo djuragan Muhammad: „To-ke, sarian, tu-baruak ko desa?” Dadi bĕling sarian Rok: „Lamin bau-si, djuragan-e, to-mo!” Bĕling-mo nja Muhammad: „E tode, laga sama bakěris, bau ěmpat-pulu nènè, apa ta datang 
waarbij wij meenden dat hij 't was (die de geschikte echtgenoot zou zijn), was, omdat waarlijk een ander hem gezonden had."

„Men wilde hem toen beloonen met veel geld, veel goud, veel edelgesteenten; maar toen heb ik hem geschikt geacht voor uwe kleindochter (mijne dochter)."

„Juist zóó, Majesteit, heeft Uwe Majesteit toen gesproken."

„Morgen dus, bode Rok, moet gij de rijksgrooten bijeen doen komen, opdat wij hun mededeelen, dat de gezagvoerder Muhammad (ons land) bereikt heeft!"'

Om kort te gaan, de bode Rok begaf zich op weg en ontbood de rijksgrooten. Den volgenden dag in de vroegte kwamen de rijksgrooten en zetten zich neer voor den vorst. De vorst sprak: „Rijksgrooten, doet bijeen komen (met ons) den heer imam en den heer kadi, opdat, dewijl nu gezagvoerder Muhammad gekomen is, wij overmorgen hier weer bijeen komen, omdat het past, dat wij overeenkomen of het voegzaam is, dat ('t huwelijk) spoedig zal plaats hebben, dan wel over langeren tijd; al zouden wij willen, dat 't spoedig plaats had, zouden wij, indien dat niet ging (en wij 't toch doorzetten) de schande er van lijden, omdat het een buitenlandsch vorst is, niet een toch, die in hetzelfde land met ons is; (wij moeten het dus zoo inrichten) dat, hoe wij de zaak ook regelen, (deze toch is een buitenlander en hoe zouden wij dan niet geheel volgens den regel handelen), wij geen schande lijden. Wij moeten dus gezagvoerder Muhammad eerst roepen, om hem te vragen, hoe de regel in zijn land is."

Om kort te gaan, den volgenden morgen werd de bode Rok uitgezonden om den gezagvoerder Muhammad te ontbieden. Hij begaf zich op weg naar den steiger. Toen gezagvoerder Muhammad hem zag, snelde hij naar hem toe en nam hem bij de hand (en zeide): „Kom snel, bode Rok!” Hij hield hem bij de hand en bracht. hem in 't schip. Gezagvoerder Muhammad sprak: „Welaan, laten wij in de kajuit gaan!” Bode Rok sprak: „Is de vorst daar in de kajuit?” Muhammad zeide: „Neen, bode Rok; laten wij binnengaan.” Zij gingen binnen. Toen zij binnen gekomen waren, deed hij den bode Rok op een stoel plaats nemen.

Om kort te gaan, bode Rok sprak: „Dat is de reden van mijne komst, ik kom u uitnoodigen, gezagvoerder Muhammad." Deze zeide : „Zullen wij dadelijk opgaan naar de stad, bode?” Bode Rok sprak: „Als 't mogelijk is, gezagvoerder, dadelijk!” Muhammad sprak: „Jongens, laat een veertigtal van $u$ de kris aandoen, want bode Rok D1. 92. 
sarian Rok kĕlek tau." Bakěris-mo tau ode sarea, balangan-mo baruak ko desa ke sarian Rok; batěris lalo pĕri datu. Bĕling-mo Muhammad pang ola ke sarian Rok: „Apa rua ia karoa datu kĕlek kita ta?” Ia-samong-mo ling sarian Rok: „No-si tu-tò, apa iasarĕmin sarea lante-mantěri ku-gita."

Tu ete lema, dapat bale datu, ia-gita ling Muhammad ada sarea lante-mantěri. Tokal Muhammad ling bungkak lante-mantěri. Mutı ia-gita ling datu tokal ling bungkak lante-mantěri Muhammad, bĕling latu: „Ma ko ta kau, anak-e!” — „Dewa, ling ninta-mo!” Dadi ramanik datu: „,Ma ko ta, anak-e!” Bĕling-mo lante-mantěri: „,Rapina lako rěpan ana, anak-e!” Rapina-mo Muhammad. Bĕling-mo datı: ,Me-mo lok; apa ada-mo mu-dapat, pidan-mo lok ia tu-sasai?" Dadi ia-samong ling Muhammad: „Kasuka dewa!” — „Apa aku, anak-e, mupakat kau ke sarea nini-kaki-mu, sarea mantěri ta; mutı mu-roa-mo ling kau ano balong, bulan balong ke sarea nini-kaki-mu, tu-sasai-mo."

Tu-ete lema, mupakat lante-mantĕri ke Muhammad. Dadi ling lante-mantěri : „Me lok, Muhammad, pětang djĕmat ta-mo tu-sasai ?” Dadi ia-samong ling Muhammad: „No monda pang kĕdjulin, karing kasuka kalepe-kadji ; apa kĕdjulin, nawar ia-suka, nawar-mo tu-sasai." — „Balong-si, anak-e!” Ngamit-mo Muhammad, turin ko kapal.

Ia-kĕlek-mo ling datu Muhammad: „Ma kau ko ta, Muhammad!” Lalo-mo Muhammad, ia-pĕri datu, tokal mĕngadap pang angkang datu. Dadi manik datu nan lako nja Muhammad: ,Apa ka ling ninikaki sarea samong kau?” — „Dadi rua ka ling, no monda lin: pang djĕmat ta-mo tu-sasai.” Bĕling-mo datu lako Muhammad: „Apa ka ling samong kau?” - „Pang djĕmat ta-mo, ka kĕtjap-kĕdjulin. „Balong-si anak-e!” Nan nja kĕdjulin-tunas, ia kĕdjulin-ngamit, iэ. kĕdjulin(-lalo) lako kapal. Dadi běling datu: Balong-si, anak-e, bada kaka-mu anak-ku datu, balong baruak nawar, olo (diri) pang bale mantĕri, ame ana-mo pang marenta!" 
is hier gekomen om ons te ontbieden." De jongens gordden humne krissen aan en gingen op naar de stad met bode Rok; rechtstreeks begaven zij zich naar den vorst. Onderweg sprak Muhammad tot bode Rok: „Wat zou de vorst toch willen om ons te ontbieden?” Deze antwoordde: „Het is onbekend, want hij heeft de rijksgrooten bijeen doen komen, naar ik gezien heb."

Om kort te gaan, toen zij de woning van den vorst bereikt hadden, zag Muhammad dat de rijksgrooten aanwezig waren. Hij zette zich achter hen. Toen de vorst hem achter de rijksgrooten zag zitten, sprak hij: „Kom hierheen mijn zoon!” — „Majesteit, hier zal ik maar blijven!” De vorst zeide (nogmaals): „Kom hierheen mijn zoon!” De rijksgrooten spraken: „Verplaats u daar naar voren, mijn zoon!” Muhammad verplaatste zich. De vorst sprak: „Hoe moet 't; want gij weet, wanneer 't geschikt zal zijn hen in het huwelijk te vereenigen?" Muhammad antwoordde: Zoo als Uwe Majesteit 't verkiest!" - „Wat mij betreft, mijn zoon, kom gij overeen met uwe grootvaders en overgrootvaders de rijksgrooten; wanneer gij met hen een dag, die goed is, een goede maand wilt hebben, zoo zullen wij ze dan in het huwelijk verbinden."

Om kort te gaan, de rijksgrooten beraadslaagden met Muhammad. Zij spraken : „Hoe zou 't zijn, Muhammad, als wij aanstaanden avond vóór Vrijdag hen in 't huwelijk verbonden?" Muhammad antwoordde: „Het ligt niet bij uw dienaar om te beslissen, alleen (hangt 't af van) het goedvinden van Mijne Heeren; want wat uw dienaar betreft, verkiest men morgen, dan kunnen zij morgen vereenigd worden.” - „Best, mijn zoon!” Muhammad nam afscheid en ging naar 't schip terug.

Hij werd ontboden door (zijn) vorst: „Kom hier, Muhammad!” $\mathrm{Hij}_{\mathrm{ij}}$ begaf zich naar den vorst en zette zich, met het gelaat naar hem gekeerd. De vorst zeide: „Welk antwoord hebben de grootvaders en overgrootvaders (de rijksgrooten) je gegeven ?”- —, Aldus geschiedde het, dat zij spraken en niets anders: dezen Vrijdag zullen zij in 't huwelijk verbonden worden.” De vorst sprak tot Muhammad: „Wat hebt gij geantwoord?” — ,Goed, dezen Vrijdag, heeft Uw dienaar gezegd. „Goed, mijn zoon!” (zeiden de rijksgrooten.) Toen heeft uw dienaar gevraagd te mogen vertrekken, om naar zijn schip te gaan. De vorst (van 't Westerrijk) zeide: Goed, mijn zoon; meld aan Uw ouderen broeder, mijn zoon den vorst, dat het 't beste is, dat hij morgen opgaat naar de stad en zijn intrek neemt in de woning van een mantri, opdat hij daar zijn maatregelen treffe." 
Tu-ete lema, pĕngantan-mo pang pětang djĕmat nan.

Tu-ete lema, djira-mo pěngantan datu, Muhammad ngamit-mo lako kapal. Dapat kapal Muhammad, běling-mo ko sarea tau ode pang kapal: „Laga, tode, pěresa sarea tali-mĕnali lajar; kĕna ada ade buruk gĕntan, olo tali bĕru; lamin ka-mo suda mu-pĕresa, bada aku!” Dadi ia-samong ling tau ode nan: „Balong-si, djuragan-e, tamo kadji-pĕresa; lamin ka-mo suda kadji-pĕresa, kadji-bada-mo kĕlam.” - „Laga-mo pěresa lema; lamin suda ka mu-pěresa, tu-lalo ngamit sarea kita, ame tu-mule-mo; datu-kita ka-mo pĕngantan, kita tu-totang-mo ina-bapa-tau!"

Tu-ete lema, lalo-mo ngamit sarea tau ode ia-bawa ling nja Muhammad. Mutu dapat bale datu, ia-gita ling datu Mĕnggĕribi Muhammad sarea ke děngan. Bĕling datu Mĕnggĕribi: „Ma ko ta kau, anak-e!" Lalo-mo nja Muhammad dampi datu, bĕling-mo nja Muhammad lako datu: „Tingka ${ }^{1}$ ) sala, ia kĕdjulin-ngamit-mo, ia kĕdjulin-mule.” Bĕling-mo datu: „Balong-si mu-pěri kaka-mu; lalo tama kau mesa ko dalam ana batěmong ke kaka-mu, ame mu-ngamit-mo!"

Tama nja Muhammad lalo batěmong; dapat dalam bilik datu nan, ramanik datu pĕngantan: ,Sisi ta tokal, adi!” Ngesok-mo nja Muhammad, sědi ode. Ramanik datu: „Lako ta, Muhammad, apa mutakit ke aku, rena kau sanak-sělaki-ku dunia aherat!" Ia-dampi-mo ling Muhammad, ia-idok-mo nè datu pĕngantan; suda ia-idok, tokalmo těrang Muhammad, ngamit-mo lako datu: „Ia kĕdjulin-mule-mo.” Bĕling datu: „Balong-si, adi-e, lè lalo-mo mu-bakĕliong, totang-mo kau ling ina ling bapa, karing ingat bae pang` desa gita sarea lantemantěri; bawa surat ta, beang ko mantěri sopo, beang lako kadi sopo!"

Tu-ete lema, turin Muhammad lako kapal; dapat kapal, rawi-mo ano; ia-kělek-mo sarea tau ling dalam kapal: „E tode, ma lako ta sarea nènè, apa mudi pukil balu tu-balajar-mo!' Barěmin sarea tau ode nan: „Laga bolat tali kapal datu, sat lako djĕmbatang!” Suda ia-sat pang djĕmbatang, barĕngo nja Muhammad: „Ingat kapal ta, tode, sama ĕntok, apa ia kami-mule-mo dunung!"

Bĕling-mo tau ling bao kapal datu: „E, bilin-mo kami lampa ling

1) Volgens anderen: sinta. (J. C. G. J.) 
Om kort te gaan, op den avond voor Vrijdag werd de vorst gehuwd.

Om kort te gaan, na afloop daarvan vroeg Muhammad verlof naar zijn schip te gaan. Daar gekomen, zeide hij tot de knapen op het schip: ,Jongens, ziet al het touwwerk na, mocht er soms bij zijn, dat vergaan is, verwisselt 't dan en stelt er nieuw touw voor; als gij 't nagezien hebt, meldt het mij dan.” De knapen antwoordden: „Goed, gezagvoerder, ik ga 't nu nazien; als dat geschied is, zal ik 't u melden." — „Ziet 't snel na; als gij het nagezien hebt, zullen wij afscheid nemen om terug te gaan; onze vorst is gehuwd, wij, wij verlangen naar onze ouders!"

Om kort te gaan, de knapen gingen afscheid nemen, geleid door Muhammad. Bij het paleis gekomen, zag de vorst van het Westerrijk Muhammad en zijne gezellen. Hij zeide: „Kom hier, mijn zoon.” Muhammad naderde den vorst en zeide tot hem: „Als $U$ 't mij niet kwalijk neemt, wil ik afscheid nemen om terug te keeren." De vorst sprak: „Gij moet u maar naar uwen ouderen broeder begeven; ga gij dan alleen binnen om hem te ontmoeten en afscheid van hem te nemen!"

Muhammad ging binnen om den vorst te ontmoeten; toen hij in diens vertrek gekomen was, zeide de jonggehuwde vorst: ,Zet u hier naast mij, broeder!" Muhammad schoof wat op, een klein weinigje. De vorst zeide: „Kom hier, wat vreest gij van mij, gij zijt immers mijn broeder in deze wereld tot in 't hiernamaals!' Muhammad kwam nader en kuste de voeten van den pas gehuwden vorst; daarna ging hij goed zitten en nam afscheid van den vorst: „Ik wensch terug te keeren.” De vorst zeide: „Goed, broeder, zeer lang hebt gij rondgezworven, uw vader en moeder verlangen naar $\mathfrak{u}$; alleen zorg er voor in ons land de rijksgrooten op te zoeken; neem deze brieven mede, geef één aan de rijksgrooten, één aan den kadi."

Om kort te gaan, Muhammad ging aan boord; toen hij daar aankwam, viel de avond; hij riep allen die op het schip waren: ,.Jongens, komt allen hier, want hierna om 8 uur zullen wij uitzeilen!" Toen de knapen bijeen waren (zeide hij): „Vooruit, maakt de touwen van het schip van onzen vorst los en bindt het vast aan den steiger!" Nadat het vastgebonden was, riep Muhammad: „Zorgt voor dit schip, jongens, houdt de wacht, want wij zullen vooruit terugkeeren!”

De lieden op het schip van den vorst zeiden: „He, laat de gezagvoerder ons werkelijk hier achter in het Westerrijk en vraagt hij ons niet om mede terug te gaan?” Muhammad antwoordde: „Wij zullen 
djuragan pang desa Mĕnggĕribi ta, no-ke adjak kami mule ling djuragan?” Ia-samong-mo ling nja Muhammad: „No-si lè kami pang desa, karing ingat paboat-adji lako datu-kita." Dadi ia-samong ling tau mbao kapal datu nan: „Balong-si, djuragan-e, doa bae-mo kami, kĕna tu-bau batěmong dua-kali; salam-doa-kami lako tau pang desa sarea; eneng kami doa belo umir-kami, kĕna 1u-bau batěmong!"

Tu-ete lema, bĕling Muhammad: „E tode, sarea nènè tama ko dalam kamar, apa ia tu-balajar pětang ta!” - „Balong-si, djuragan-e!" Ia-sarĕmin sarea ko dalam kamar, ia-suki lawang kamar ling Muhammad ola luar. Bĕling-mo nja Muhammad: „Lamin aku karue bitara, ngibar kau kapal!" Ngibar kapal Muhammad, lis ka ling dalam běrang. Tĕlı bulan lè pang ola, dapat desa Muhammad, saběling-mo mĕriam dua lusin. Bĕling sarea mantĕri: „Nonda mule datu-kita, kapal Muhammad bae-si ada; kuda rua ta, kĕna ada susa; laga lema sama lalo kětoan, ame tu-tò lema!"

Barari-mo sarian, pĕnggawa lako kapal nja Muhammad; sorong sampan, nonda bose; sorong sĕkutji, nonda dajong; ngangan sarea ling sisi lit. Ia-gita ling Muhammad mbao kapal, bĕling ko tau ode pěno nan: „Kuda nasa tau pang darat ana, tode, kĕna nonda ola turin; laga saturin sĕkutji-kita, ame lalo ete ko darat, bawa turin ko bao kapal ta!"

Lalo-mo sĕkutji ĕntek ko darat; dapat sisi tampar, bĕling sarian, pĕnggawa sarea: „Suru kami dea bĕlè datang̀ kětoan nènè, kamikĕlangkabit ita; kami-sorong sampan, nonda bose; kami-sorong sěkutji, nonda dajong; nan nja bua kami-ngangan pang sisi tampar ta.” - „Suru kami djuragan datang ete (nè) pěnggawa ke nè sarian bawa turin ko kapal."

Tu-ete lema, ĕntek pĕnggawa ke sarian ko bao sĕkutji, ia-dajongmo ling tau ode, dapat-mo kapal. Bĕling Muhammad: „Ma lema, nè pĕnggawa, nè sarian, ĕntek ko bao kapal ta!" Ěntek-mo ko bao kapal nè pĕnggawa ke nè sarian, ia-ěnti ima ling nja Muhammad, bawa tama ko kamar. Bĕling-mo nè sarian, nè pěnggawa: „Me nja datu kita?” - „Apa-mo ia-buja ling nè sarian, datu-kita sĕnang; pĕngantan rame." 
niet lang in ons land vertoeven, alleen zorgen voor de taak, die wij voor onzen vorst te verrichten hebben." De lieden op het schip van den vorst antwoordden: „Goed, gezagvoerder, bid slechts voor ons, dat wij elkander een tweede maal kunnen ontmoeten; onze heilbeden voor de lieden in ons land; laten zij voor ons bidden, dat wij lang mogen leven, om hen weder te zien."

Om kort te gaan, Muhammad sprak: „Jongens, gaat allen in de kajuit, want vanavond zullen wij uitzeilen!” - „Goed, gezagvoerder!" Allen werden in de kajuit verzameld en de deur werd van buiten met een boom gesloten door Muhammad. Toen zeide hij : „Als ik van goddelijke afkomst ben, vlieg dan op gij schip!' Het schip vloog uit de rivier. Drie maanden was Muhammad onderweg; toen hij zijn land bereikte, deed hij twee dozijn kanonschoten lossen. De rijksgrooten spraken: „Onze vorst is niet teruggekeerd, alleen het schip van Muhammad is er, waarom zou dit toch zijn, misschien is er een moeilijkheid; gaat allen vragen, opdat wij 't snel weten!"

De bode en de pĕnggawa's snelden heen om zich naar het schip van Muhammad te begeven. Toen ze het bootje te water gebracht hadden, waren er geen pagaaien; toen ze de sloep te water gebracht hadden, waren er geen riemen; beteuterd stonden allen aan de zeekant. Toen Muhammad dit van het schip af zag, zeide hij tot de knapen: „Waarom zijn er zoovele menschen daar aan land, misschien hebben zij geen middel om aan boord te komen, laat ons een sloep strijken, om ze van land af te halen en brengt hen dan hier op 't schip!"

De sloep ging naar land; aan het strand gekomen, zeiden de bode en de pěnggawa's : „Daar hebben ons nu de hoofden uitgezonden om mijnheer te ondervragen, daardoor zijn wij zooeven geheel in de war geraakt. Toen wij een sampan te water lieten, waren er geen pagaaien; toen wij een sloep te water lieten, waren er geen riemen; daardoor staan wij beteuterd aan de zeekant.” — „De gezagvoerder heeft ons gezonden om de pĕnggawa's en mijnheer den bode af te halen en op 't schip te brengen."

Om kort te gaan, zij gingen in de sloep, werden geroeid door de knapen en kwamen aan het schip. Muhammad sprak: „Komt snel hier, heeren pěnggawa's en mijnheer de bode, komt hier aan boord!" Zij stegen aan boord, Muhammad hield hen bij de hand en bracht hen in de kajuit. De heer bode en de heeren pĕnggawa's spraken: „Waar is onze vorst ?" - ,Wat wilt ge nog meer hebben, heer bode, onze vorst is welvarend, hij heeft een luisterrijke bruiloft gevierd." 
Bĕling mo nja Muhammad: „E tode, maeng-mo bawa ai panas nan, ame tu-ěntek ko darat barěma ke nè pĕnggawa, tu-lalo těmong lante-mantĕri-kita, lok hal tu-lalo ko Mĕnggĕribi!" Ia-angkat-mo dulang ai panas ling tau ode nan, inim-mo ling dalam kamar ke nè pĕnggawa, nè sarian.

Tu-ete lema, turin-mo ko darat ka ling bao kapal; dapat darat, ia-iring-mo Muhammad ke gĕnang ke tambir lako bale mantěri. Dapat bale mantěri, ia-gita ling mantěri : „Ma lema, anak Muhammad, ku-totang kau, ia-mo tau ka mate tělas kĕbali, rea ku-kaměri gita kau. Apa rungan datu-kita, anak Muhammad-e? Nan-si nja ia ku-kětoan kau nan."

„Sělamat ka kalalo-kědjulin lako Mĕnggĕribi, sarea kaběrěkat kalepe-kadji, sěnang datu-kita pang ana."

Ia-samong-mo ling mantĕri : ,Alhamdu l'illah, anak-e; mutu bada aku tau ada kapal Muhammad datang, rea ku-kamĕri ; rena ku-kasusa, sěbab nonda kapal datu ku-gita, bua ku-suru lalo nè pĕnggawa, nè sarian, lalo pĕri kau, anak-e!"

Bĕling-mo nja Muhammad: „Tingka ${ }^{1}$ ) sala, dea, ada surat kĕdjulin-bawa, lako kalepe-kadji sopo, lako tuan kadi sopo."

Bĕling lante-mantěri: „Lalo kĕlek tuan kadi ke tuan imam, tode, adjak barĕma; tingka kĕtoan kau ling tuan kadi: apa kĕlek aku ling dea, djina salema tau tu-barĕma ke kau: ada Muhammed ka dapat, tuan kadi!"

Dadi bĕling-mo tuan kadi: „Alhamdu l'illah, nanta, apa rungan ia-bawa ling Muhammad, nè sarian?” - „Alhamdu l'illah, tuan kadi, bĕrĕkat tuan kadi, sĕlamat-si, běrĕkat kalalo ko Mĕnggĕribi." Ete lamong tuan kadi, ete sĕrban, balangan-mo barĕma ke nè sarian lako bale mantěri. Dapat-mo tuan kadi bale mantĕri, ia-beang-mo surat ling mantĕri lako tuan kadi. Ia-tarima-mo ling tuan kadi surat nan, iauleng-mo pang angkang mantěri. Dadi ling dalam surat nan sasai nja Muhammad ke lala, sanak-sowai datu.

1) Volgens anderen: sinta. (J. C. G. J.) 
Muhammad sprak (voorts): „Jongens, vooruit, brengt de koffie, dan kunnen wij tezamen met de heeren pĕnggawa's aan land gaan en onze rijksgrooten opzoeken en spreken over onze tocht naar het Westerrijk!" Het schenkblad met de koffie werd voorgediend door de jongens en Muhammad met de heeren pĕnggawa's en de heer bode dronken koffie in de kajuit.

Om kort te gaan, men ging aan land; aldaar werd Muhammad begeleid door inlandsche en Europeesche trommen tot aan de woning van den (eersten) rijksgroote. Aldaar aangekomen, zag deze hem (en zeide) : „Kom snel, mijn zoon Muhammad, ik verlang naar $\mathfrak{u}$, als een doode, die weder levend geworden is, zoo groot is mijne vreugde $\mathrm{u}$ te zien. Wat voor nieuws is er van onzen vorst, mijn zoon Muhammad? Dat is 't wat ik u vragen wilde."

"Gelukkig is de gang van uwen dienaar naar het Westerrijk geweest; door den geheelen zegenrijken invloed van Mijnheer voelt onze vorst zich daar aangenaam!"

De rijksgroote antwoordde: „Lof zij Allah, mijn zoon; toen de lieden mij berichtten, dat 't schip van Muhammad er was, was mijne vreugde groot; maar daarom was ik ongerust, omdat 't schip van den vorst er niet was, naar ik zag; daarom beval ik den heeren pĕnggawa's en den heer bode zich naar u te begeven, mijn zoon!"

Muhammad sprak: „Als u 't mij niet ten kwade duidt, heer, heeft uw dienaar brieven medegebracht, een voor Mijne Heeren en een voor den heer kadi."

De rijksgrooten zeiden: ,Gaat mijnheer den kadi en mijnheer den imam roepen en noodigt ze uit te zamen met $\mathrm{u}$ (hier te komen); als de heer kadi u vraagt: waartoe roepen mij de hoofden, zij doen ons toch snel tegelijk met $\mathrm{u}$ gaan, (zegt dan): Muhammad is aangekomen, heer kadi!"

De heer kadi sprak (toen hem dit bericht was) : „Lof zij Allah, die beste man, wat voor nieuws heeft hij gebracht, heer bode?" „Lof zij Allah, mijnheer de kadi, door den zegenrijken invloed van mijnheer den kadi, is (de vorst) welvarend; vol zegen is de gang naar het Westerrijk geweest." Mijnheer de kadi kreeg zijn baadje en zijn hoofddoek en begaf zich op weg, te zamen met mijnheer den bode naar de woning van den mantri. Aldaar gekomen, gaf deze hem den brief. De kadi nam dezen aan en opende hem in tegenwoordigheid van de rijksgrooten. In den brief stond, dat men Muhammad moest doen trouwen met de prinses, de zuster van den vorst. 
Bĕling-mo mantĕri lako tuan kadi: „Surat lako aku nan-si ling, ba ta laga-mo sarĕmin sarea, ame tu-mupakat sarea tau!" Dadi bĕlingmo mantĕri: „E sarian, laga-mo ling dalam ano ta bada sarea tau ta ling dalam desa kita ta, ame nawar puan tu-suru tama sarea tau luar desa, ame mĕnong rua mupakat-kita!"

Bue-mo barĕmin sarea tau. Bĕling-mo mantĕri lako tuan kadi ke tuan imam: „Mupakat-mo kita hukum ke adat, lamin mupakat-mo, ame tu-boat-mo lema!” Bĕling-mo tuan kadi: „Balong-si tu-salema; mutu ade těrang, na sangělè, apa kĕna dapat ling rusak; apa de lěnge bae-si tu-sangělè-mo, ame pěri těrang.” Samong ling mantěri : „Tuan kadi, kěrana kadi ěnti hukum; sarea ade lěnge, ade tĕrang ia-boat ling tuan kadi."

Tu-ete lema ling boa, ia-boat-mo ling lante-mantěri ke tuan kadi sarea isi-měsigit. Bĕling-mo tuan kadi lako mantěri: „Maeng-mo tu-kělek Muhammad, ame tu-bada Muhammad lok ia tu-sasai, ame njaman tò diri!" Ia-kĕlek-mo ling mantěri Muhammad, datang-mo pĕri mantěri. Bĕling-mo mantěri: „Tuan kadi-mo bada Muhammad, ame njaman ia-tò." Ia-bada-mo ling tuan kadi, bĕling tuan kadi lako nja Muhammad: „E anak Muhammad-e, nan-si nja ku-kĕlek kau, ia ku-sasai kau ke datu-dara."

Bĕling nja Muhammad: „Eneng ampin, tuan kadi, saribu ampin, me lok ia ku-pina sowai datu, rena aku ulin datu?" Ia-samong-mo ling tuan kadi ke mantěri: „Saměnta, Muhammad-e, mu-pina sowai, no kami-těngan ia no kami-sasai kau, kěrana surat lako kami : sasai nja Muhammad ko clatu-dara, nja gĕntan aku marenta ling dalam desa nan."

Bĕling-mo tuan kadi lako ina bapa nja Muhammad: „Ma-mo lako bale-kaku sarea nènè, apa datu-lara, mantěri boat parenta; nja Muhammad, aku boat parenta ke tuan imam." Ia-bawa-mo nja Muhammad lako bale tuan kadi. Tu-ete lema, pang pětang hĕmis, pěngantan-mo nja Muhammad ke datu-dara. Dadi batja doa tuan 
De rijksgroote zeide tot den kadi: „De brief aan mij heeft denzelfden inhoud, laten wij nu allen doen bijeen komen, opdat wij allen beraadslagen!” De mantri sprak: „Bode, breng bericht nog dezen dag, aan alle menschen in ons land, opdat wij morgen of overmorgen alle menschen, die buiten de hoofdplaats wonen, kunnen bevelen op te komen, opdat zij hooren hoe wij overeengekomen zijn!"

De lieden waren altemaal verzameld. De mantri sprak tot den heer kadi en den heer imam: „De geestelijke wet en 't gewoonterecht (de ge sstelijke en wereldlijke overheid) beraadslagen, als zij overeenstemmen (zegt het dan), opdat wij snel kunnen te werk gaan!" Mijnheer de kadi zeide: „Het beste is, dat wij het snel verrichten; wanneer er iets goeds is (te doen), moeten wij het niet uitstellen, want dan zou het kunnen mislukken; want alleen wat slecht is, moeten wij uitstellen, opdat het zich ten goede wende." De mantri antwoordde: „Goed, heer kadi, want op u rust de handhaving der godsdienstige wetten; al wat slecht of wat goed is, (dat in orde te brengen) is uw taak."

Om kort te gaan, de rijksgrooten met den kadi en het moskeepersoneel brachten de zaak in orde. De kadi sprak tot de rijksgrooten: „Welaan, laten wij Muhammad roepen en hem mededeelen hoe wij hem in het huwelijk zullen verbinden, opdat hij zich gelukkig gevoele door het zelf te weten!" Muhammad werd door de rijksgrooten ontboden en hij begaf zich tot hen. Zij zeiden: „Mijnheer de kadi zal het aan Muhammad mededeelen, opdat hij zich gelukkig gevoele door het te weten." De heer kadi deelde het aan Muhammad mede, terwijl hij sprak: „Mijn zoon Muhammad, daarom heb ik u doen roepen, wij willen $\mathrm{u}$ in het huwelijk verbinden met de prinses."

Muhammad zeide: „Ik vraag vergiffenis, mijnheer de kadi, duizendmaal, hoe zou ik de vorstin tot vrouw kunnen maken, dewijl ik een onderdaan van den vorst ben!" Mijnheer de kadi en de rijksgrooten antwoordden: „Het moet zoo zijn, Muhammad, dat gij haar tot vrouw maakt, wij durven niet $\mathrm{u}$ niet in het huwelijk te verbinden. want er zijn brieven aan ons (waarin staat): verbindt Muhammad in het huwelijk met de prinses, hij zal mij vervangen in het bestuur van het land."

De heer kadi sprak tot de ouders van Muhammad: ,Welaan, (gaat) gij allen naar mijn huis, want wat de prinses betreft, voor haar regelen ve rijksgrooten de zaak; voor Muhammad ik en de heer imam." Muhammad werd naar het huis van den heer kadi gebracht. Om kort te gaan, op den avond voor Vrijdag, huwde Muhammad 
kadi : „Alhamdu l'illah, Muhammad-e, balong gama mu-marenta ling dalam desa ta, kěna dadi sarea bua kaju pang mu-marenta kau, apa mutu datu dunung, sarea dadi apa-apa: bua kaju, djaran, kĕbo, dadi sarea. Nan-si lue ling-ku lako kau, kảring mantěri ada paladjar liin lako kau."

Bĕling-mo tuan imam: ,,No-mo ku-bĕling aku, apa sopo ia paladjarku ke tuan kadi."

Bĕling-mo mantěri : „E anak Muhammad-e, kau lampa ia tau bale rango ta, sělamat mu-marenta ke pědi sarea ruwajat; tingka ka ia-sili ling datu dunung, ada sala, lamin sědi-si, kau na sili, Muhammad-e, ame běri kau ling ruwajat tau sarea!"

Tu-ete lema, ka pěngantan nja Muhammad, bĕling nja Muhammad lako mantěri, lako tuan kadi : ,Nan-si ling-kědjulin ta ka-mo adjar kĕdjulin ling tuan kadi ke mantěri, kědjulin ada ia ling-kědjulin lako tuan kadi: sagěras hukum kalepe-kadji, mutu ada boat no roa ling hukum, bada aku! Nan-si lue ia ling-kĕdjulin lako kalepe-kadji tuan kadi."

Bĕling-mo kěbali nja Muhammad lako mantĕri: „Lok ka adjar kĕdjulin ling mantěri ku-djonjong sa-dua ima-ku, ku-olo ko bao otakku. Kĕdjulin ada-si ia ling-kědjulin ko mantěri, ka tu-adjar kĕdjulin ta: satětap marenta kalepe-kadji, mutu anung no ia-roa ling adat, bada aku, kěna těrang desa!"

Tu-ete lema, bĕling-mo Muhammad lako tuan kadi, lako mantěri : „Ingat sama djaga desa, aku ia ku-roa lalo gita datu-ku lako Mĕnggĕribi, apa ka manik datu ko aku: na mu-lè, Muhammad-e, datang gita aku lema; aku ia ku-balajar, ingat desa!"

Dadi, tu-ete lema, ia-marenta-mo Muhammad ia balajar ; bĕling-mo lako sarian Depak: „E sarian, lalo běli gula gěrěsik lako labu nawar!” Bĕling-mo sarian Depak: „Balong-si, dewa, pida rua ia kĕdjulin-bĕli gula?” — „Bĕli dua pikil, tĕlı pikil, sarian-e!” Ia-beang-mo ringgi lako sarian Depak ling datu. Mĕngka balangan-mo sarian Depak lako bale. Dapat bale, ia-ngo nja Saban : „E Saban, lalo sakěna lape djaran, boko tolang, ame tu-djual lako toke pang labu, ame mule mudi boko gula djaran!" 
met de prinses. Toen verrichtte de heer kadi de gebeden (en sprak) : „Lof zij Allah, Muhammad, moge gij goed regeeren in dit land, opdat de vruchten in het land, waar gij regeert, slagen, want toen de vorige vorst regeerde, slaagde alles, vruchten, paarden, buffels, alles gedijde. Dat is alles wat ik $u$ te zeggen heb, meer weet ik niet, tenzij de rijksgrooten nog eene andere leering aan $u$ te geven hebben."

De heer imam zeide: „Ik zal niets zeggen, want mijne leering is één met die van den kadi."

De (eerste) rijksgroote sprak: „Mijn zoon Muhammad, gij zult dan werkelijk de man in het groote huis hier (de vorst) zijn; wees gelukkig in 't regeeren en ontferm u over het volk; als de vorige vorst toornig was op iemand, dewijl hij zich schuldig gemaakt had, wees gij dan, als de schuld gering is, niet toornig, opdat het volk u beminne."

Om kort te gaan, nadat hij gehuwd was, sprak Muhammad tot de rijksgrooten en den heer kadi: „Dat heb ik te zeggen, nadat uw dienaar nu leering ontvangen heeft van den heer kadi en de rijksgrooten, uw dienaar wil tot den heer kadi zeggen: doe het geestelijk bestuur (hukum) streng zijn; als er iets gedaan wordt, wat niet gewild wordt door de geestelijke wet, meld het mij dan! Zooveel heb ik te zeggen aan mijnheer den kadi."

Wederom sprak Muhammad tot de rijksgrooten: „Hetgeen de rijksgrooten mij, uw dienaar, geleerd hebben, draag ik op mijne beide handen, plaats ik op mijn hoofd. Uw dienaar heeft ook iets te zeggen tot de rijksgrooten, nadat hij leering ontvangen heeft: mijne heeren moeten met kracht het bestuur voeren, als er iets geschiedt, dat niet door de adat gewild wordt, meldt het mij, opdat het land welvare!"

Om kort te gaan, Muhammad zeide (nu) tot den heer kadi en de rijksgrooten: „Zorgt er voor, dat gij allen 't land bewaakt, want ik wil naar het Westerrijk gaan, om onzen vorst te zien, want deze heeft tot mij gezegd: blijf niet lang weg, Muhammad, kom spoedig naar mij zien; ik wil dus uitzeilen, zorgt voor het land!’

Om kort te gaan, Muhammad nam zijne maatregelen om uit te zeilen; hij zeide tot bode Depak: „Bode, ga morgen naar de haven om suiker te koopen!” Deze sprak: „Goed, Majesteit, hoeveel suiker moet uw dienaar koopen?” - „Koop 2 of 3 pikol, bode!” De vorst gaf hem rijksdaalders. De bode Depak begaf zich naar huis. Aldaar gekomen, riep hij (zijn dienaar) Saban: „Saban, doe 't paard het vrachtzadel aan en belaad het met beenderen, dan kunnen wij die gaan verkoopen bij den tokohouder aan de haven en, als wij later terugkeeren, het paard met suiker beladen!" 
Ia-olo-mo pang angkang bale toke tolang nja Saban, ia-timang-mo tolang ling toke; běling sarian Depak: „Pida bĕrat sarea tolang nan, toke?” Dadi běling-mo toke: ,Saratis lima-pulu.” Dadi bĕling sarian Depak: „Ku-timang pang desa dua pikil; ba ta no monda, sĕbab kadji ke toke kurang sědi, lěbe sědi, no-si dadi měngapa ${ }^{1}$ ); ta nja ringgi, toke, kadji-eneng bĕli gula gĕrĕsik lako toke." Běling-mo toke: „Pida ia mu-běli gula, sarian Depak ?” — „Bau sa-pikil, dua pikil-si.” Bĕling-mo toke: „Sa-pikil ke dua pikil, dadi tĕlu pikil, sarian Depak-e!” Běling-mo sarian Depak: „Ba nan-mo, toke!”

Ia-timang-mo ling toke, ia-bawa-mo mule ling Saban. Dapat bale datu, bĕling-mo datu: „Apa de mu-boko nan, Saban?” Bĕling-mo nja Saban: „Gula, dewa.” - „Gula gěrěsik-ke nan, Saban?” - „Gula gĕrěsik, dewa!” - „Maeng bawa ěntek ko bale, Saban!” Ia-bawa-mo ěntek ling Saban. Bĕling-mo datu lako nja Saban: „Lalo lema mule, Saban, suru sarian datang lema lako ta!” Ngamit-mo nja Saban lako datu, mule Saban lako bale.

Ia-dapat sarian Depak pang bale, mutu mangan. Suda mangan sarian Depak, lis ko luar. Bĕling-mo nja Saban: „E puwa, ka manik datu lako kadji : lalo mule, Saban, suru sarian Depak lema datang!" Mutu ia-bada ling nja Saban sarian Depak, bĕling sarian Depak ko sowai: „Maeng ko ta pabua, ia ku-mama, apa kělek aku datu!” Suda mama sarian Depak, lalo-mo pěri datu.

Mutu dapat bale datu, ia-gita-mo ling datu: „Ma lema, sarian, ĕntek ko bao ta!” Běling-mo sarian Depak ia-šamong datu: „Balongsi, dewa!” Bĕling-mo datu: „Pida ka mu-bĕli gula ta ?” — „Dadi duapulu ringgi bĕli gula ta.” Bĕling-mo datu: „Ingat, sarian Depak, apa aku ia ku-balajar ko Mĕnggĕribi, ku-totang datu, apa lè-mo ku-bilin nanta, datu pang desa tau." Njamong-mo sarian Depak: „Adjak kĕdjulin lalo, dewa, sate kědjulin-gita Mĕnggĕribi !" Bĕling-mo datu: „No-mo datang kau, sarian-e, ĕntok bale ta, kuwasa kau bĕlè! No-si ku-lè era pang Mĕnggĕribi, ka-mo ku-batěmong era ke datu-kita, ku-ngamit-mo, ku-mule.” Dadi bĕling sarian Depak: „Balong-si, dewa, lamin lalo nawar puan kalepe-kadji, kĕdjulin-nurit kĕdjulin.” — „Balong-si, sarian-e, lamin mu-rasate gita Mĕnggĕribi.”

$\left.{ }^{1}\right)$ De tusschengevoegde Maleische woorden naar Soembawareesche uitspraak moeten de tegen den tokohouder gebezigde taal aanduiden. (J. C. G. J.) 
Saban stelde de beenderen voor de toko, de tokohouder woog ze, waarop bode Depak sprak: „Hoe zwaar zijn die beenderen, tokohouder?” Deze zeide: „150 (kati).” Bode Depak sprak: „Ik heb ze in de stad gewogen, toen wogen zij 2 pikol; nu 't hindert niet, dat ik iets verschil met den tokohouder, de een zegt iets minder, de andere iets meer, het doet er niet toe; hier zijn rijksdaalders, tokohouder, ik vraag u broodsuiker om te koopen!" De tokohouder zeide: „Hoeveel wilt gij koopen, bode Depak ?” — „Zoowat één pikol, twee pikols.” De tokohouder zeide (weder) : „Een pikol en twee pikols maakt 3 pikols, bode Depak.” Deze zeide: „Zoo is 't, tokohouder!”

De suiker werd afgewogen door den tokohouder en door Saban naar de stad gebracht. Toen hij bij de woning van den vorst kwam, zeide deze: „Wat hebt gij op uw paard geladen, Saban?” Saban zeide : „Suiker, Majesteit!” — „Is het broodsuiker, Saban?” — „Ja, Majesteit!” — „Breng die boven in huis, Saban!” Saban bracht ze boven. De vorst sprak tot Saban: „Ga spoedig naar huis, Saban, en beveel bode Depak, spoedig hier te komen!" Saban verzocht den vorst verlof om heen te gaan en ging naar huis.

Hij trof bode Depak in zijn huis aan, bezig met eten. Nadat hij gegeten had, kwam hij buiten. Saban sprak: „Heer, de vorst heeft tot mij gezegd: ga terug, Saban, en beveel bode Depak snel te komen." Toen Saban hem dit mededeelde, zeide bode Depak tot zijne vrouw: „Geef hier de sirihdoos, ik wil sirih kauwen, want de vorst ontbiedt mij!" Nadat hij een sirihpruim genomen had, begaf hij zich tot den vorst.

Toen hij bij de woning van den vorst gekomen was, zag deze hem: „Snel, bode, kom hier boven!” Bode Depak zeide in antwoord tot den vorst: „Goed, Majesteit!” De vorst sprak: „Voor hoeveel hebt gij deze suiker gekocht?” - „Twintig rijksdaalders was de prijs ervan!” De vorst zeide (wederom) : „Wees zorgzaam, bode Depak, want ik wil uitzeilen naar het Westerrijk, ik verlang naar den vorst; reeds lang heb ik den goeden vorst achtergelaten in het land der vreemdelingen!” Bode Depak antwoordde: „Vraag Uw dienaar mede te gaan, Majesteit, hij verlangt het Westerrijk te zien!" De vorst sprak: „Gij moet daar niet komen, bode, bewaak dit huis, gij hebt er de macht over. Ik zal ook niet lang in het Westerrijk blijven; als ik onzen vorst zal ontmoet hebben, zal ik afscheid nemen en terug gaan.” Bode Depak sprak: „Goed, Majesteit, als U later eens gaat, zal Uw dienaar medegaan.” — ,Goed, bode, als gij verlangt het Westerrijk te zien." 
Tu-ete lema, balajar-mo datu lako Mĕnggĕribi, tĕlu bulan lè dalam palajar. Dapat-mo ling siip-djaga, bĕling-mo Muhammad: „E tode, laga ěntek ko bao tiang, masi-ke lĕga kapal ling dalam bĕrang ana!" Ia-samong ling tau ode nan ling bao tiang: „Masi lĕga kapal ling dalam bĕrang ana.” - „Lamin měnan, no-mo tu-rapat kita ano ta, ame na gita kita ling kapal ana."

Dapat-mo ling pětang, běling-mo Muhammad lako sarea tau ode nan: „Laga tama ko dalam kamar sarea nènè!” Tama sarea tau ode nan ko dalam kamar, ia-suki lawang kamar nan ola luar ling Muhammad. Bĕling nja Muhammad: „Lamin aku karue bitara, ngibar kau kapal!" Ngibar kapal lako anok djĕmbatang datu Mĕnggĕribi.

Siip djaga mĕleng tau ling bao kapal datu: „E ada kapal djuragan Muhammad datang!” Bĕling sa-tau: „Bola nja ta, rena no-po-ka lè ka mule lako desa-kita, tĕria ada datang, ling-kau!" Ia-samong-mo: „Ma-mo gita!” Lis nja tau ka bĕling nan, mutu ia-gita: „Tutu-si lampa, lok gantjang, djuragan Muhammad, me lok no ia bĕri ling datu?"

Bĕling-mo tau ode mbao kapal djuragan Muhammad: „Na běling „,djuragan Muhammad" ling nènè, apa ka-mo dadi datu pang desakita." Ia-samong-mo ling tau mbao kapal datu: „Sai ka boat pina datu ?" Dadi bĕling-mo tau ode: „Sanak-sowai datu-kita ia-pina sowai.” Bĕling-mo nja tau ling bao kapal datu nan kĕbali: „No-ke sili datu, ia-pina sowai sanak-sowai datu?” - „Me lok ia lalo sili datu, rena adat boat sukat, hukum boat sukat?" Dadi ia-samong ling tau mbao kapal datu nan: „Kĕle adat boat sukat, hukum boat sukat, mara-ling-kau, lamin datu-kita nonda pang desa?" Ia-samong ling tau ode: „Gila-ke ia-sukat ling mantěri, ling kadi, lamin nongka basuru datu?"

Tu-ete lema, dapat pukil tĕlu sore, bĕling-mo Muhammad lako tau ode sarea: „Laga sama bakĕris sarea nènè, ame tu-lalo ngajap lako datu-kita!" Sakĕna kĕris tau ode sarea, balangan-mo barěma lalo ngajap lako datu. Mutu dapat angkang bale datu, ia-gita-mo ling datu 
Om kort te gaan, de vorst voer naar het Westerrijk, drie maanden duurde de vaart. Des morgens vroeg sprak Muhammad: „Jongens, klimt in de mast (en ziet) of er nog vele schepen daar in de rivier liggen!” De jongens antwoordden van uit de mast: „Er zijn nog vele schepen, daar in de rivier.” - ,In dat geval zullen wij vandaag niet bij 't land komen, opdat (de lieden op) de schepen ons niet zien."

Toen het avond geworden was, zeide Muhammad tot de jongens: „Gaat allen in de kajuit!” $Z_{i j}$ gingen allen binnen en Muhammad sloot de deur van de kajuit van buiten. Hij sprak: „Als ik van goddelijke afkomst ben, vlieg dan op, gij schip!" Het schip vloog tot den steiger van den vorst van het Westerrijk.

Vroeg in den morgen ontwaakten de lieden op het schip van den (vroegeren) vorst: „He, daar is 't schip van gezagvoerder Muhammad teruggekomen!” Een van hen sprak: „Dat is een leugen, want hij is nog niet lang geleden naar ons land teruggekeerd, en dan zou hij, volgens uw zeggen, in eens teruggekomen zijn!” (Een ander) antwoordde: „Welaan, zie eens!” Hij, die zoo gesproken had ging naar buiten; toen hij het schip zag zeide hij : „Het is werkelijk waar, wat is gezagvoerder Muhammad toch vlug, hoe zou de vorst niet van hem houden?"

De jongens op het schip van gezagvoerder Muhammad zeiden: „Zegt niet (meer) ,gezagvoerder Muhammad”, want hij is vorst geworden in ons land." De lieden op het schip van den (vroegeren; vorst antwoordden: „Wie heeft hem vorst gemaakt?” De knapen spraken toen: „De zuster van onzen vorst heeft hij gehuwd.” De lieden op het schip van den (vorigen) vorst zeiden wederom: ,Zou de vorst niet toornig zijn, dat hij zijne zuster tot vrouw heeft genomen?” - „Hoe zou hij gaan toornen, dewijl zoowel het wereldlijk als het geestelijk gezag hem uitgehuwelijkt heeft?" Toen antwoordden de lieden op het schip van den (vorigen) vorst : „Al heeft zoowel het wereldlijk als het geestelijk gezag hem uitgehuwelijkt, zooals gij zegt, als onze vorst nu niet in het land was, (hoe mocht dit dan) ?' De knapen antwoordden: „Zouden de rijksgrooten en de kadi zoo gek geweest zijn hem in het huwelijk te verbinden, als de vorst het niet bevolen had?"

Om kort te gaan, om 3 uur in den namiddag zeide Muhammad tot de knapen: „Gordt allen uw kris aan, want wij gaan onze opwachting bij den vorst maken." Zij deden hunne krissen aan en begaven zich gezamentlijk op weg om hunne opwachting bij den vorst te maken. Toen zij aan het paleis kwamen, zag de vorst van het Westerrijk D1. 92. 
Mĕnggĕribi Muhammad: „Ma lema, anak, alhamdu l'illah, nanta anak-ku, ka-mo dapat ta!” Bĕling-mo datu Mĕnggĕribi : „E tode, lalo bada datu ko dalam ana: ada ka datang djuragan Muhammad; bada těrang datu-mu!"

Lalo-mo tau ode tama ko dalam bilik ana. Dapat dalam bilik ana tau ode, ia-bada-mo datu: „Ada ka dapat djuragan Muhammad, dewa!” Bĕling datu-sowai nan: „E nanta!” Lis-mo datu-sowai lako luar, lalo gita djuragan Muhammad, ia-turit-mo ling sĕlaki, ia-dapat tokal barĕma ke datu Měnggĕribi. Bĕling-mo datu-sowai nan: „E nanta adi-ku, ka dapat lampa, apa de mu-bawa aku ka ling desa ana ?" - „Ada-si, dewa, ade kědjulin-bawa, sama sědi sarea, malim desa miskin.” Bĕling-mo datu-sowai : „Te-mo, tama ko bilik, adi-e!” Iasamong ling Muhammad: „Balong, dewa!”

Dapat dalam bilik ana, ia-beang-mo surat ka pang mantěri ke pang tuan kadi, ia-ete-mo ling datu. Mutu ia-uleng, ia-batja ling datu-sowai nan: „E nanta kau lampa, adi Muhammad-e, dadi datu ling dalam desa-kita ana! Rame-ke mutu mu-pĕngantan ?” - „Rame, dewa, me lok ade parenta kalepe-kadji, nan-si lok ia-boat kĕdjulin ling lantemantěri kalepe-kadji, dewa, ke hukum kalepe-kadji sarea isi měsigit."

Tu-ete lema, sa-bulan dua bulan-mo lè djuragan Muhammad pang Mĕnggĕribi, tunas-mo ngamit ia mule. Bĕling-mo datu: „Balong-si, adi-e, mu-mule, tĕrang marenta pang desa-kita, me lok mutu kumarenta aku, nan lok mu-turit ling kau.” Bĕling-mo datu nan : „Lalomo basĕlaman ke datu loka, ame mu-ngamit-mo lako datu lok ia mumule lako desa-kita."

Ngamit-mo nja Muhammad lako datu Mĕnggĕribi nan : „Kĕdjulinmule-mo, dewa!” Ia-samong-mo ling datu Mĕnggĕribi: „Apa ling kaka-mu ita ke kau?” Ia-samong-mo ling Muhammad: „Balong-mo marenta pang desa, me lok mutu ku-marenta aku, nan lok mu-marenta kau, ame pědi kau ling tau sarea, dadi pade, antap, lamin balong tumarenta, dadi djaran, kĕbo. Dadi běling-mo kĕdjulin: balong, dewa, běrěkat kalepe-kadji!"

Bĕling-mo datu Mĕnggĕribi : „Pidan sate mu-balajar, anak-e?”„Lamin barĕma ke kasuka kalepe-kadji, puan pang rawi hĕmis sate 
Muhammad (en zeide): „Kom snel hier, mijn zoon, lof zij Allah, dat mijn beste zoon hier gekomen is!" De vorst van het Westerrijk zeide (voorts) : „Jongens, gaat daar binnen aan den (jongen) vorst mededeelen, dat gezagvoerder Muhammad gekomen is, meldt het behoorlijk aan uwen vorst!"

De jongens gingen de kamer binnen en meldden den vorst: „Gezagvoerder Muhammad is aangekomen, Majesteit.” De vorstin zeide: „Die beste man!” Zij kwam naar buiten om den gezagvoerder Muhammad te zien en werd door haren echtgenoot gevolgd; bij den (ouden) vorst van het Westerrijk gekomen, zetten zij zich met hem neder. De vorstin zeide: ,Mijn beste jongere broeder, gij zijt dan werkelijk gekomen, wat hebt gij voor mij uit het land daarginds medegebracht?” - „Uw dienaar heeft wel iets medegebracht, Majesteit, al te maal kleinigheden, (het land immers) is bekend als een arm land.” De vorstin sprak: „Welaan, jongere broeder, laten wij daar in de kamer gaan!” Muhammad zeide: „Goed, Majesteit!”

In de kamer gekomen, gaf hij brieven over van de rijksgrooten en van den kadi en de vorst nam ze aan. Nadat ze geopend waren, las de vorstin ze (en zeide): „Gij, mijn beste jongere broeder Muhammad, zijt dan werkelijk vorst geworden in dat land van ons daarginds! Was er veel drukte, toen gij trouwdet?” — „Veel drukte, Majesteit; zooals mijn Heer bevolen had, is ten opzichte van Uw dienaar gehandeld door Uwe rijksgrooten, Majesteit, en door Uwe geestelijke hoofden, het geheele moskeepersoneel."

Om kort te gaan, een maand of twee bleef Muhammad in het Westerrijk, toen verzocht hij verlof om terug te keeren. De vorst sprak: „Het is goed, broeder, dat gij terugkeert, regeer goed in ons land, zooals ik deed in den tijd dat ik regeerde, zoo moet gij volgen!" (Voorts) sprak de vorst : ,Ga den ouden vorst vaarwel zeggen en neem afscheid van hem (en zeg) hoe gij naar ons land wilt terugkeeren!"

Muhammad nam dan afscheid van den (ouden) vorst van het Westerrijk: „Uw dienaar gaat terug, Majesteit.” Deze antwoordde: „Wat heeft uw oudere broeder (de jonge vorst) zoo even tot u gezegd?” Muhammad antwoordde: „Regeer goed in het land, zooals ik geregeerd heb, zoo moet gij regeeren, dan zullen alle menschen van u houden en rijst en boonen zullen slagen, als men goed regeert, zoo ook paarden, buffels. Toen zeide Uw dienaar: Goed, Majesteit, door Uw zegen!"

De vorst van het Westerrijk sprak: ,Wanneer wenscht gij uit te zeilen, mijn zoon?” - „Als het overeenkomt met Uw goedvinden, 
kědjulin-balajar.” Bĕling-mo datu Měnggěribi : „Balong-si mu-balajar pang rawi hĕmis nan, anak-e."

Ngamit-mo, turin ko kapal Muhammad; dapat mo kapal, běling-mo lako sarea tau ode: „Laga gita sarea tali-mĕnali lajar, me ade buruk gĕntan, apa ia tu-balajar nawar rawi!" Bĕling-mo sarea tau ode lako dĕngan sarea: „Laga-mo pĕresa sarea tali lajar nan, lamin ka-mo djira mu-pĕresa, tu-lalo-mo bada djurangan!" Ia-pĕresa sarea ling tau ode, me de buruk ia-gěntan-mo, suda-mo ka ia-gĕntan, lalo bada djuragan ko dalam kamar. „Balong-si, tode, nĕngka rawi tu-balajar.”

Tu-ete lema, dapat ling sělam ano, bĕling-mo nja Muhammad: „Laga-mo bolat tali kapal nan pang djěmbatang ke tali lako kapal datu ana!" Ia-bolat-mo ling tau ode sarea. Bĕling-mo tau ode sarea: .,Sělamat kau pang ninta, kami to-mo kami-mule sarea kami!” Iaměnong ling tau pang kapal datu, nangis sarea sate mule. Bĕling Muhammad: „Na nangis, tode-e, lamin ku-datang mudi era, ku-adjak kau mule!" Ia-samong ling tau mbao kapal datu nan: „Alhamdu l'illah, djuragan-e, pědi gama kami, lamin datang mudi era, kamitotang-mo desa kami!” Bĕling-mo nja Muhammad: „Ingat pang desa tau, na ia-mo pang desa-kita katěman-nènè ling desa tau!"

Tu-ete lema, ia-satama ko dalam kamar tau ode sarea. Bue-mo tama ko dalam kamar sarea, ia-suki ola luar ling nja Muhammad, mĕngka bĕling-mo nja Muhammad: „Lamin aku karue bitara, ngibar kau kapal!" Mĕngka ngibar-mo kapal nan. Dadi ling dalam palajar nan tĕlu bulan, dapat-mo desa, sabĕling mĕriam dapat desa dua-olas kali.

Bĕling lante-mantĕri sarea ia-kĕlek sarian Depak: „Lalo gita kapal ana, kita to lè nonda datu-kita, no monda tau nudja, ngisung, rantok no monda bĕling, tu-barata, tĕria nja datang sabĕling mĕriam!" Lalo sarian Depak ia-gita kapal; dapat sisi tampar, ia-gita kapal datu nja; kamĕri sarian Depak, barari lalo bada lante-mantěri: „Sila, basědia, kĕlek tuan imam, tuan kadi, kapal datu datang!" 
verlangt $\mathrm{Uw}_{w}$ dienaar overmorgen in den namiddag voor Vrijdag uit te zeilen.” De vorst van het Westerrijk sprak : „Het is goed, mijn zoon, dat gij in den namiddag voor Vrijdag uitzeilt."

Muhammad nam afscheid en ging aan boord; aldaar zeide hij tot de knapen: „Ziet al het touwwerk van de zeilen na en al wat vergaan is, verwisselt dat, want morgen namiddag zullen wij uitzeilen!” De knapen zeiden onder elkaar: „Komt, onderzoekt al de touwen van de zeilen, en als gij het onderzocht hebt, laten wij het dan aan den gezagvoerder gaan zeggen!' Zij onderzochten alles; wat vergaan was, vervingen zij, en daarna gingen zij het in de kajuit aan den gezagvoerder melden. „Goed, jongens, van avond zeilen wij uit."

Om kort te gaan, toen de zon onderging, zeide Muhammad: „Komt, maakt los de touwen, waarmede het schip aan den steiger gebonden is en bevestigt het schip van den (vorigen) vorst!" De jongens maakten ze los. Zij zeiden: „Vaart gij hier wel, wij allen gaan nu terug." Toen de lieden op het schip van den (vorigen) vorst dit hoorden, begonnen zij allen te weenen uit verlangen naar hun land terug te keeren. Muhammad sprak: „Weent niet, jongens, als ik later terug zal komen, zal ik u vragen om mede naar ons land terug te gaan." De lieden op het schip van den vorst antwoordden: „Lof zij Allah, gezagvoerder, heb toch medelijden met ons, als gij later terug zult komen, wij verlangen naar ons land!" Muhammad zeide: „Denkt er om, dat gij in een vreemd land zijt en dat grij aldaar u niet kunt gedragen als in ons eigen land!"

Om kort te gaan, hij deed alle knapen in de kajuit gaan. Nadat zij er allen in gegaan waren, sloot Muhammad de deur van buiten met een boom en sprak: „Als ik van goddelijke afkomst ben, vlieg dan op, gij schip!" Het schip vloog op. Toen waren zij drie maanden in de vaart, vervolgens bereikten zij hun land, zij losten toen 12 maal saluutschoten.

De rijksgrooten zeiden, nadat zij den bode Depak ontboden hadden : „Ga naar dat schip zien, wij hebben nu reeds lang onzen vorst niet, er is dus niemand, die rijst stampt, korte of lange rijstblokken zijn er niet, welke geluid geven, dewijl wij rouwen, en plotseling komt het (schip) daar en lost kanonschoten." Bode Depak ging naar het schip zien; aan het strand der zee gekomen, zag hij dat het 't schip van den vorst was; verheugd snelde hij naar de rijksgrooten, om het hun mede te deelen: „Als ' $t$ u belieft, maakt u gereed, ontbiedt den heer imam, den heer kadi, 't schip van den vorst is gekomen!' 
Ia-kělek-mo tuan kadi, tuan imam, barĕmin-mo sarea tau. Ia-lalomo ete datu lako kapal; turin-mo datu ka ling bao kapal; ia-sěntekmo lako djuli, ia-isong-mo ling tau pěno, ia-bawa-mo mule. Dapat bale, mutu rik anar, ia-sawit-mo ke loto kuning, ěntek-mo ko bao bale, ěntek-mo sarea lante-mantěri, tuan kadi, tuan imam, dapat mbao bale, tokal-mo sarea.

Běling-mo mantěri: „Apa-mo rungan rua datu, sanak dewa pang Mĕnggěribi ana ?” Dadi ia-samong ling Muhammad: „Insja'Allah, datu-kita balong marenta pang Mĕnggěribi, gĕntan mĕntua.” Bělingmo tuan kadi: ,E anak-e, dadi no-mo ia turin lampa datu-kita ko bawa angin ta?" Měngka ia-samong-mo ling nja Muhammad: „Apa ia-buja turin lako desa lěnge ta? Desa ana, apa de tu-buja, ia nonda sarea?"

\section{VI}

Acla dea dua basanak-sĕlaki, sama rua basowai sa-dua. Bĕling de rea: „Lamin sowai anak-kau, adi-e, sĕlaki anak-kaku, tu-sukat era.” Bĕling-mo de ode: „Balong-si, kaka-e.” Dapat ling masa, baranak ade ode sowai, baranak ade rea sĕlaki.

Tu-ete lema, rea-rea anak, mate-mo bapa, mate ina. Dea rea no-soka ia-sěpan kĕmanak, ina ka-mo mate, bapa ka-mo mate, no-so-ka ia-djampang kĕmanak.

Tu-ete lema, rea-mo kĕmanak, anak dea rango-mo, no-so-ka salinggita basěmpu-sai. Ia-mĕnong rungan bae-si, ia-bada lalu nan: „Balong adi-sia ana.” Dadi běling lalu nan: „Te tu-lalo gita!” Balangan-mo ke tau ka bĕling balong nan ia lalo gita. Mutu ia-gita tama ko dalam karang, ia-sampat lawang bale. Bĕling-mo lalu nan: „Me ka lako baeng bale ta rua, ia-sampat lawang ?" Dadi běling dĕngan badampi bale: „Nonda."

Bĕling-mo tau ka bĕling nonda nan: „Te-mo tu-lalo ko bale-kakumo!" Dadi ia-samong ling lalu nan: „Te tu-lalo ko bale-sia-mo, ina-e, apa bale ta nonda baeng." Lalo-mo lalu lako bale; ĕntek ko bao bale, bĕling-mo tau ia-pina ina ling lalu nan: „Lamin sia-datang 
Zij ontboden den heer kadi, den heer imam, alle lieden kwamen bijeen. Men ging den vorst van het schip afhalen; deze ging van boord; men deed hem in een draagstoel plaats nemen, de menigte droeg hem en bracht hem naar zijne woning. Aldaar gekomen bestrooiden zij hem, toen hij de trap betrad, met gele rijst; hij ging naar boven in huis, alle rijksgrooten, de heer kadi en de héer imam gingen ook naar boven, aldaar gingen zij allen zitten.

De rijksgrooten zeiden: „Wat is er voor nieuws van den vorst, den broeder van Uwe Majesteit in het Westerrijk?" Muhammad antwoordde: „Als God wil, regeert onze vorst in welstand in het Westerrijk, ter vervanging van zijn schoonvader." De heer kadi sprak: „Mijn zoon, zal 't dan werkelijk niet gebeuren, dat onze vorst hier naar het land beneden den wind komt?" Toen antwoordde Muhammad: „Wat zou hij zoeken, door te komen in dit leelijke land? Wat men ook zoeken kan, is dat alles niet in het land daarginds?"

\section{VI}

Er waren eens twee aanzienlijke broeders, beiden waren getrouwd. De oudste sprak: „Als gij eene dochter krijgt, mijn jongere broeder, en ik een zoon, dan zullen wij ze met elkander laten trouwen." De jongere zeide: „Goed, oudere broeder!” Toen de tijd gekomen was, kreeg de jongste eene dochter, de oudste een zoon.

Om kort te gaan, toen de kinderen opgroeiden, stierven de vader en moeder van het meisje. De oudste der adellijke broeders sprak nooit meer over zijne nicht, nadat vader en moeder dood waren, liet hij zich niets aan haar gelegen liggen.

Om kort te gaan, toen de nicht van dev edelman volwassen was en ook zijn zoon groot was, hadden neef en nicht elkander nooit gezien. Alleen hoorde de Jonker eens het bericht van iemand, die hem zeide: „Uw jongere zuster is schoon.” Toen zeide hij : „Laten wij eens naar haar gaan zien!" Hij begaf zich op weg met de persoon, die gezegd had, dat zij schoon was, om naar haar te gaan zien. Toen zij hen het erf zag opkomen, sloot zij de huisdeur. De Jonker sprak: ,Waar zou de persoon, die het huis bewoont, heen gegaan zijn, dat de deur gesloten is ?" Een dienst(vrouw), die op hetzelfde erf woonde, zeide : „Er is niemand."

Zij, die gezegd had, dat er niemand was, zeide: „Laat ons naar mijn huis gaan!” De Jonker sprak: ,Welaan, laten wij naar uw huis gaan, moeder, omdat de persoon, die dit huis bewoont er niet is." De Jonker ging naar hẹt huis; toen hij boven gekomen was, zeide de 
nawar puan, sia-bakĕre berek, sapu berek, sia-djual djadi, nan nja de ia-běri ling adi-sia, no-mo takit sia, apa no ia-tò rua-sia."

Dapat rawi, běling-mo lalu lako dĕngan: „E tode, nawar siip pĕra kěbo, apa ada lako ia ku-bawa djadi!" Tu-ete lema, dapat siip-djaga, adla djadi ia-bawa ling tau ode nan, dua pangisi. Bĕling-mo lalu nan lako tau ode nan: „Lemar ling kau djadi ta, apa ada lako ia tu-bawa!” Dapat-mo ola, ia-ete-mo kĕre tau ode nan ke sapu tau ode nan, iabeang-mo kěre lalu ke sapu: „Anti aku pang ninta, na kĕna mu-lalo lako me-mé bělè, kěna ku-mule mudi, nonda kau, ku-sili kau!" Dadi ia-samong ling tau ode nan: „Lalu, balong-si, me-po ia lako-ku, ku-těngan ia ku-bilin sia?”

Ia-ete djadi ling lalu pang tau ode nan, ia-lemar-mo tama ko dalam desa. Mutu dapat sisi karang lala nan, barĕngo-mo lalu nan: „Ma bĕli djadi, nènè!” Bĕling-mo lala nan: „Kuda ia-mo sěda tau djual djadi ?” Dadi ia-samong ling tau ode dĕngan lala nan: „Tau djual djadi-si, lala-e!" — „Lalo kĕlek lema, bawa ko ta!”

Turin-mo tau ode dĕngan lala nan, ia-ngo-mo tau djual djadi: ..Bawa ko ta djadi-kĕlam!” Ia-bawa-mo ling lalu nan lako angkang bale lala nan. Bĕling-mo lala nan: ,Adjak ěntek ko bao bale ta tau djual djadi nan!” Běling-mo tau ode nan: „Bawa ěntek djadi-kĕlam ko bale lala ana!” Běling-mo lalu nan: „No ku-těngan ko bale tau dadi dea, aku tau kĕban, kĕre-ku berek, sapu-ku berek, no gampang ku-ĕntek ko bale tau dadi dea, tau ulin ia-mo aku ta." Bĕling-mo lala nan: ,No-si kuda-kuda, ma bawa ěntek djadi-mu lako ta.” Ia-bawamo ĕntek ling lalu nan.

„Pida-mo bĕli djadi ta sa-pangisi ?” Dadi ia-samong ling lalu nan: „,Tu-takar-po!” Bĕling-mo lala nan : „Me takar-mu ?” Ia-samong ling lalu nan: „Nonda takar-ku.” Bĕling-mo lala nan: „Ete kudong namo ana, tode, kenang tu-takar djadi ta!" Lalo-mo tau ode nan, ia-lalo ete kudong namo, ia-bawa-mo ling tau ode nan, ia-beang-mo lako lala. „.Mu-roa-ke sa-takar sa-kepeng djadi-mu? ? Ia-samong ling lalu nan: 
vrouw, die hij als moeder aangesproken had: „Als $\mathfrak{u}$ later nog eens komt, moet $\mathfrak{u}$ een gescheurde kain en hoofddoek dragen en moet gij melk te koop aanbieden, dan zal uwe jongere zuster op $\mathrm{u}$ gesteld zijn en niet meer bang zijn, want zij kent u niet."

Toen de avond gevallen was, zeide de Jonker tot een ondergeschikte: ,Jongen, melk morgen vroeg de buffels, want ik wil ergens heen melk brengen!' Om kort te gaan, toen het vroeg in den morgen was, was de melk, ter hoeveelheid van twee emmers, door den jongen man gebracht. De Jonker zeide tot hem: „Draag gij deze melk, want ik wil ze ergens heen brengen!" Op weg nam hij de kain van den jongen man en diens hoofddoek en gaf hem zijn kain en hoofddoek, (terwijl hij sprak): „Wacht mij hier, ga vooral nergens heen, mocht ik later terugkomen, terwijl gij er niet zijt, dan word ik boos op je!" De jongeman antwoordde: „Goed, Jonker, waar zou ik heen gaan, zou ik u durven verlaten?"

De Jonker nam de melk van den jongeman over en droeg die naar het dorp. Toen hij naast het erf van de Jonkvrouw gekomen was, riep hij: „Koopt melk, heeren!” De Jonkvrouw zeide: „Hoe, 't is alsof (ik) de stem hoor van iemand, die melk te koop aanbiedt?" Een dienstmeisje van de Jonkvrouw antwoordde: „Er is ook een melkverkooper, Jonkvrouw.” — „Ga hem spoedig roepen en breng hem hier!"

Het meisje kwam beneden en riep den melkverkooper: „Breng uwe melk hier!" De Jonker bracht ze voor het huis van de Jonkvrouw. Deze zeide: „Laat dien melkverkooper hier boven komen.” Het meisje zeide: „Breng uwe melk boven in het huis van de Jonkvrouw daar!” De Jonker zeide: „Ik durf niet naar het huis van iemand, die tot de aanzienlijken behoort, ik ben maar een landman, mijn kain en hoofddoek zijn gescheurd, het is een heel ding voor mij om in het huis te komen van iemand, die tot de aanzienlijken behoort, een laaggeborene als ik.” De Jonkvrouw sprak: „Dat komt er niets op aan, kom, breng uw melk hier boven!" De Jonker bracht de melk boven.

„Hoeveel kost één emmer van die melk ?” De Jonker antwoordde: „Laten wij ze meten!” De Jonkvrouw sprak: „Waar is uw maat?” De Jonker antwoordde: „Ik heb geen maat.” De Jonkvrouw sprak: „Meisje, neem de deksel van die waterkruik daar en laten wij daar de melk mede meten!' Het meisje ging de deksel halen, bracht hem en gaf hem aan de Jonkvrouw. „Wilt gij één duit per maat voor uw melk hebben?” De Jonker antwoordde: „Er is niets tegen, als u de 
„No monda, lamin sia-ete-mo sa-kepeng sa-takar.” Ia-djual-mo djadi lako lala nan, ia-ete sarea djadi ling lala.

Bĕling-mo lala nan : „E tode, ete pabua-ku ana, bawa ko ta!” Ia-etemo pabua ling tau ode nan, ia-bawa-mo lako angkang lala. Dadi běling lala: „Ma-mo mama.” Dadi ia-samong ling lalu nan: „Balong-si.” Mama-mo lalu nan ita, suda mama, ngamit-mo. Dadi běling lala nan: ,.Lamin ada djadi nawar puan, bawa lako ta, na bawa ko tau lin!”

Turin lalu nan ling bao bale lala nan. Bĕling-mo lala lako dĕngan: ..Mura djadi tau ana ita; tingka tu-běli lako tau lin s-uwang sa-takar, nja beang tau sa-kepeng sa-takar; nanta tau nan, mura djadi beang tau!"”

Tu-ete lema, balangan lalu nan, ia-dapat-mo tau ode dĕngan lalu nan: „Maeng ko ta kĕre-ku, sapu-ku; ma-mo ete kĕre-kau, laga lema, ame tu balangan, kěna gita tau!" Balangan-mo dua ke tau ode, bĕling-mo lalu nan: ,Ka-mo ku-gita lala ana ita bělè, balong!" Bĕling-mo tau ode: „Tingka ka sia-kenang kĕre balong, sapu balong, no-mo těngan gita sia, ka sia-bau badampi (ke lala) nan ita." Bĕlingmo lalu nan: ,.Tutu měrang balong bĕlè ; nawar djaga měra!”

Siip-djaga mĕra tau ode nan, ia-bawa dua pangisi, lalo beang lalu. Bĕling-mo lalu: ..Lemar ling kau-mo, te-mo tu-balangan lema, kěna gita tau ling dea-bini, kĕlek tau era!” Lema balangan dua. Dapat ka pang barěnang mula, běling-mo lalu nan: „Maeng ko ta kěre-mu ke sapu-mu, kĕna ada tau gita tau!' Ia-beang-mo ling tau ode kĕre ke sapu; basalin-mo lalu, balangan-mo lalu, ia-ete djadi nan, ia-lemar-mo.

Mutu dapat angkang bale lala nan, barĕngo-mo: „Ma bĕli djadi!” Ia-měnong ling lala nan: ,Lalo kĕlek lema tau djual djadi ana, kěna nja tau ka tu-běli djadi perap!" Ia-lalo-mo kĕlek ling tau ode nan: ..Bawa djadi-kělam ko bale lala apa ia běli djadi!” Ia-bawa-mo. „E tau perap-si lampa; ma bawa ĕntek lako ta djadi-mu!"

Ia-bawa-mo ĕntek ko bale lala nan; ia-takar-mo djadi ling lala nan. Ia-kĕtoan-mo ling lala nan: ,Me desa-mo kau, to waja mu- 
melk neemt voor één duit per maat." Hij verkocht dan de melk aan de Jonkvrouw, deze nam al de melk.

Zij sprak: „Meisje, krijg mijn sirihdoos en breng die hier.” Het meisje kreeg de sirihdoos en bracht die voor de Jonkvrouw. Deze sprak: „Komaan, neem een sirihpruim!” De Jonker antwoordde: „Goed.” De Jonker nam een sirihpruim, daarna vroeg hij verlof om heen te gaan. De Jonkvrouw sprak: „Als gij morgen of overmorgen melk hebt, breng die dan hier, niet naar een ander!"

De Jonker daalde af van het huis van de Jonkvrouw. Deze zeide tot hare bediende: „De melk van dien man, die hier zooeven was, is goedkoop; als wij ze bij iemand anders gingen koopen, zou ze 10 duiten de maat zijn, hij geeft ze ons voor één duit de maat; och, die man, wat geeft hij ons de melk goedkoop!"

Om kort te gaan, de Jonker begaf zich op weg en kwam bij den jongeman, die een dienaar van hem was: „Geef hier mijn kain en mijn hoofddoek, vooruit, neem je kain, wat vlug, opdat wij kunnen weggaan, men mocht ons eens zien!' Hij ging met den jongeman op weg en sprak: „Ik heb dan zooeven de Jonkvrouw gezien, zij is schoon!” De jongeman sprak: „Als gij een mooie kain en een mooie hoofddoek hadt gedragen, zou zij u niet hebben durven zien, nu hebt u en de Jonkvrouw van zooeven elkander kunnen naderen!" De Jonker sprak: ,Zij is dan werkelijk zeer schoon; ga morgen ochtend melken!"

In den vroegen ochtend melkte de jongeman, hij bracht twee emmers en gaf die aan den Jonker. Deze zeide: „Draag gij haar, vooruit, laat ons snel op weg gaan, anders mocht de edelvrouw (mijne moeder) ons eens zien en ons roepen!" Zij begaven zich snel op weg. Toen zij kwamen, waar zij de eerste maal stil gehouden hadden, zeide de Jonker: „Geef hier uw kain en hoofddoek, er mocht eens iemand zijn die ons zag!" De jongeman gaf zijn kain en hoofddoek; de Jonker verkleedde zich en begaf zich op weg, terwijl hij de melk nam en die droeg.

Toen hij voor het huis der Jonkvrouw kwam, riep hij: „Koopt melk!” De Jonkvrouw hoorde hem: „Ga snel dien melkverkooper daar roepen, misschien is hij de man, van wien wij gisteren gekocht hebben.” De bediende ging hem roepen : „Breng uwe melk naar het huis der Jonkvrouw, want zij wil melk koopen!” Hij bracht ze. „He, dat is werkelijk de man van gisteren; breng je melk hier boven!"

Hij bracht de melk boven in het huis der Jonkvrouw; deze mat de melk. Zij vroeg hem: „Uit welk dorp zijt gij, dat gij op dezen 
dapat ta?” — „Dò desa-kaku, sia-e.” — „Pukil pida ka mu-bilin desa-mu?” — „Pukil dua ku-bilin desa-ku aku, sia-e.” Bĕling-mo lala nan: „E tode, beang mè nanta tau ta, apa dò desa; tĕnga pĕtang ka balangan, to wajang ${ }^{1}$ ) dapat ta, panas tian, beang mè lema!”

Ia-beang-mo mè ling tau ode; suda mangan, bĕling-mo lalu nan: „Alhamdu l'illah, no-mo ku-mule ko bale mudi; batěris ku-lalo gita kěbo, apa běsir-mo tian-ku!” Bĕling-mo lala nan: „No-mo ku-ngo kau, batĕris-mo bawa ko ta djadi-mu nawar!" Ia-kĕtoan-mo ling lala nan: ,Ka-mo-ke mu-basowai ?” Dadi ia-samong ling lalu nan: „Kamo ku-basowai." Ia-kětoan-mo ling lala nan : „Ada-mo-ke anak-mu ?” Ia-samong ling lalu nan: „Ada-mo.” — ,Sowai-ke, sělaki-ke anakmu?" - „Sowai." — „Apa singin anak-mu nan, ame njaman tukĕlek kau ?” Dadi ia-samong ling lalu nan: „Si Kĕbo-kuning singin ulin-sia."

Tu-ete lema, balangan-mo lalu mule; bĕling-mo lala nan: „Lok balong ate Bapa si Kĕbo-kuning lako kita; siip-djaga datang bawa djadi !"

Tu-ete lema, pětang bĕling lako tau ode dĕngan lalu nan: „Pĕra kěbo-mu rawi ano, ame tu-lalo pětang bawa djadi dumin lala nan!" Dapat mĕnggĕrib, lalo bawa djadi. Bĕling-mo lala nan: „Sai nan ?” Ia-samong ling lalu nan: ,Aku, sia-e!” — „Aku sai ?” — „Aku Bapa si Kĕbo-kuning!” — „Beang lawang lema, tode, Bapa si Kĕbo-kuning beang tau cljadi."

Ia-bawa-mo ĕntek djadi ko bao bale, ĕmpat pangisi; ia-ete-mo ling lala nan: „No-mo datang těngari, pětang bae-mo datang!” .,Balong-si,” ling ia-samong ling Bapa si Kĕbo-kuning. Suda ia-beang mè, ngamit-mo. Bĕling-mo lala nan: „Na, mudi, Bapa si Kĕbo-kuning, apa ada ia ku-kětoan kau; ada sowai-mu masi-ke?" Dadi iasamong ling Bapa si Kĕbo-kuning: „Lè-mo ka mate.” — , „Tingka roa ke aku, Bapa si Kĕbo-kuning, ku-roa-si!"

Dadli běling Bapa si Kĕbo-kuning: „No gampang tau ulin marua aku ta, ia ku-ngĕntang ling bale-sia; sia tau dadi lala, aku tau ulin."

1) Zoo het hs.; 1. waja, of waja-ng? (P. V.) 
tijd van den dag hier komt?” — ,Mijn dorp is ver, Vrouwe.” „Hoe laat hebt gij uw dorp verlaten ?” — „Om twee uur heb ik mijn dorp verlaten, vrouwe.” Zij sprak: „Meisje, geef wat eten aan dien besten man hier, want zijn dorp is ver; in de helft van den namiddag is hij al op weg gegaan en om dezen tijd is hij hier gekomen, hij moet honger hebben, geef hem snel wat eten!"

Het meisje gaf gekookte rijst; nadat hij gegeten had, zeide de Jonker: „Lof zij Allah, nu behoef ik hierna niet meer naar huis te gaan; ik kan meteen door naar de buffels gaan zien, want ik ben verzadigd.” De Jonkvrouw sprak: „Ik zal u niet meer aanroepen, breng morgen uw melk meteen hier!' Zij vroeg verder : „Hebt gij al eene vrouw?” De Jonker antwoordde: „Ik heb al eene vrouw getrouwd.” Zij vroeg (verder) : „Hebt gij al een kind?” De Jonker antwoordde :,Ja!”- „Een meisje of een jongen ?”- —Een meisje.”„Hoe heet uw dochter, (zeg 't mij), dat wij u kunnen aanspreken met een naam, die aangenaam is.” De Jonker antwoordde : „Kĕbo-koening is de naam van uwe dienaresse."

Om kort te gaan, de Jonker begaf zich op weg om naar huis te gaan; daarop sprak de Jonkvrouw: „Wat is de vader van Kĕbokoening ons toch welgezind; vroeg in den morgen komt hij ons melk brengen."

Om kort te gaan, toen de avond gevallen was, zeide de Jonker tot zijn jongen volgeling: „Melk uwe buffels in den namiddag, dan kunnen wij, als 't donker is, de melk, voor de Jonkvrouw bestemd, brengen." Toen het de tijd voor 't gebed bij zonsondergang was, gingen zij de melk brengen. De Jonkvrouw zeide: „Wie is daar?” De Jonker antwoordde : „Ik, vrouwe.” — „Wie is ik?”- „Ik, Vader van Kĕbo-koening!” - „Geef hem snel toegang, meisje, Vader van Kĕbo-koening komt ons melk geven!”

Hij bracht de melk boven in huis, ter hoeveelheid van vier emmers; de Jonkvrouw nam ze, (en zei) : „Gij moet niet meer over dag komen, kom maar als 't donker is!" - „Goed,” was het antwoord van Vader van Kĕbo-koening. Nadat men hem rijst gegeven had, verzocht hij verlof om heen te gaan. De Jonkvrouw sprak: ,(Ga nog) niet, (ga) later; ik heb u iets te vragen, hebt gij uw vrouw nog?" De Vader van Kĕbo-koening antwoordde: „,Zij is al lang gestorven!” — „Als gij mij wilt hebben, Vader van Kĕbo-koening, dan wil ik wel."

Hij sprak: „Het is geen kleinigheid voor een laaggeborene als ik om in uw huis te verblijven; gij zijt eene Jonkvrouw, ik een laaggeborene." De Jonkvrouw sprak: „Dat zal er niet op aan komen.” 
Dadi ia-samong ling lala nan: „Ia ta kuda!” Bĕling-mo Bapa si Kĕbo-kuning: „Běnar-si ling-sia, no gampang; sia tau dadi dea, aku tau ulin; ia ku-ngĕntang ling bale sia, no bau dua-ng-ano, samate-mo aku ling tau."

Tu-ete lema, turin-mo Bapa si Kĕbo-kuning mule; dapat-mo ola, bĕling-mo lako tau ode dĕngan lalu nan: „Maeng ko ta kĕre-ku, sapu-ku, ame lema tu-balangan." Mutu suda kenang kĕre, sapu lalu, bĕling-mo lako tau ode: „Apa rua lok lala nan bĕlè, roa sangěntang tau ?" Ia-samong-mo ling tau ode: „Lok no tò rua-sia; sia basapu herek, bakĕre berek; tingka sia-kenang ade balong, no sia-bau gita." Dadi balangan-mo dua. Běling tau ode nan : „Sia-ngěntang-mo nawar pětang, lalu!"

Tu-ete lema, sělam ano, bawa-mo djadi, lalo tělu. Mutu dapat bale lala nan, ěntek mo lalu ko bale lala nan. Bĕling-mo lala nan : „E nanta Bapa si Kĕbo-kuning bawa djadi!" Tau ode dua nan mule-mo, lalu ngĕntang-mo ling bale lala nan.

Suda ia-beang mè ling lala nan, ngamit-mo: „Ta-mo ku-mule.” Bĕling-mo lala nan: ,Nawar-mo mu-mule!” Bĕling-mo Bapa si Kĕbokuning: „No ku-tĕngan ngĕntang, sia-e.” — „Sai ia tĕngan, lamin aku-sangĕntang kau?” Ia-samong ling Bapa si Kĕbo-kuning: „Me ling-sia-mo!"

Tu-ete lema, dapat těnga pĕtang, ngĕrđga Bapa si Kĕbo-kuning, ia-ěnti nè lala nan. Těrĕmpat lala nan, bĕling lala nan: „Sai to?”„Aku, Bapa si Kĕbo-kuning.” Dadi bĕling lala nan : „E Bapa si Kĕbokuning-e, na měnta lok-tau; lamin mu-roa-si aku, tanang balong, tukělek tuan imam, tuan kadi, ame sanika tau tĕrang-tĕrang; na tu-boat lěnge, nongka balong!” - „Lamin nan-po ling-sia, lala-e, balong-si; nawar, pětang djěmat ku-datang bawa djadi, tu-kĕlek-mo tuan imam ke tuan kadi."

Dapat ling pĕtang, ada-mo lalo Bapa si Kĕbo-kuning bawa djadi; ia-lalo-mo kĕlek tuan kadi, tuan imam; ada-mo datang sadua. Bĕlingmo lala: „Nan-si aku-kělek sia, dea papin tuan kadi, tıan imam, 
Hij zeide: „(Al) meent $u$ wat $\mathfrak{u}$ zegt, het is geen kleinigheid; $u$ behoort tot de adellijken, ik ben een laaggeborene; wil ik verblijven in uw huis, dan zal ik dat geen twee dagen kunnen; men zal mij dooden."

Om kort te gaan, hij ging naar huis; toen hij op den weg gekomen was, zeide de Jonker tot zijn jongen bediende: „Geef hier mijn kain en hoofddoek en laten wij ons spoedig op weg begeven!' Nadat de Jonker zijn kain en hoofddoek aangedaan had, zeide hij tot den jongeman: „Wat is er toch met de Jonkvrouw, zij wil ons in haar huis doen blijven!” De jongeman antwoordde: „De zaak is, dat zij niet weet wie gij zijt; $u$ toch draagt een gescheurde kain, een gescheurde hoofddoek; indien $\mathrm{u}$ mooi goed aanhadt, zoudt $\mathrm{u}$ haar niet hebben kunnen zien.” Beiden begaven zich toen op weg. De jongeman sprak: „U moet morgen nacht blijven, Jonker!”

Om kort te gaan, toen de zon onderging, bracht hij de melk, terwijl hij met twee bedienden liep. Toen zij het huis van de Jonkvrouw bereikt hadden, ging de Jonker naar boven in huis. De Jonkvrouw sprak: „He, daar is die beste Vader van Kĕbo-koening, die melk brengt." De twee jonge mannen keerden terug, de Jonker bleef in het huis van de Jonkvrouw.

Toen zij hem te eten gegeven had, wilde hij verlof vragen om heen te gaan (en zeide): „Nu zal ik naar huis gaan!” De Jonkvrouw zeide: „Morgen kunt gij naar huis gaan.” De Vader van Kĕbokoening sprak: „Ik durf niet blijven, Vrouwe!” - „Wie zou (u iets) durven (doen), als ik u laat blijven ?" De Vader van Kĕbo-koening antwoordde: ,Al wat u zegt (zal ik opvolgen)!”

Om kort te gaan, toen het midden in den nacht was, kroop de Vader van Kĕbo-koening naar de Jonkvrouw en vatte haar bij de voet. Zij schrok wakker en zeide: „Wie is hier?”- „Ik, de Vader van Kĕbo-koening.” Toen zeide de Jonkvrouw: „Vader van Kĕbokoening, laten wij niet zoo doen; als gij mij hebben wilt, laten wij dan den juisten weg volgen en mijnheer den imam en mijnheer den kadi roepen, om ons geheel zoo als 't behoort, in het huwelijk te verbinden; laten wij niet slecht handelen, dat zou niet goed afloopen!' - „Als dit uw woord is, Jonkvrouw, dan is het goed; morgen in den naävond voor Vrijdag zal ik melk komen brengen, wij zullen dan den heer imam en den heer kadi ontbieden."

Toen de naävond gekomen was, had de Vader van Kĕbo-koening melk gebracht; hij ging den heer kadi en den heer imam roepen; beiden waren dan gekomen. De Jonkvrouw sprak: „Daarom heb ik 
sanika aku ke Bapa si Kĕbo-kuning!" Ia-samong-mo ling tuan imam: ,E sai ia těngan sanika sia ke tau ulin, rena sia pĕno adi-kaka-sia ?" Dadi ia-samong ling lala : „No-mo sia-tò ling sia, sanika aku bae-mo!”

Dadi ia-sanika-mo ling tuan imam, tuan kadi. Suda ia-sanika, inim ai panas; suda inim ai panas, ngamit-mo mule tuan imam, tuan kadi. Tu-ete lema, lalo-mo mule lako bale.

Dapat marua kabiasa, mule (lalı nan) lalo gita kĕbo; bĕling ko sowai : „Ta ku-lalo gita kĕbo-ku.” Ia-samong-mo ling sowai : „Lema mule!” Batěris mule ko bale; bĕling-mo dea-laki: „Me ka lako-mu, anak, to dua pětang mu-nonda ?” — „Ka ku-lalo gita sanak-sowai-ku; dapat bale sanak-sowai-ku, těria ku-gita rua balong, dadi ku-kĕlek-mo tuan imam, tuan kadi, suru sanika aku.”- „Apa-mo ling sěmpu-saimu gita kau?" - ,No-si tò rua-ku, apa ku-bakěre berek, basapu berek; ka-si kětoan aku: apa singin-mu kau, dadi ku-samong: aku Bapa si Kĕbo-kuning; runtung ano ku-beang djadi."

Bĕling-mo dea-laki ke dea-bini: „No-si nan lok-tau, apa kita tıdadi dea; tu-pěngantan ke balong-balong; boat tau ulin basio." Bĕlingmo dea-laki ke dea-bini: „Man-mo lako me-mé, anak, ame ku-sukat kau tĕrang-tĕrang, ame ta ku-kĕlek tuan kadi ke tuan imam, ku-suru lalo bakětoan lako sěmpu-sai-mu!” Dadi ia-samong ling lalu: „Kuda, ka-mo ku-nika; tuan kadi, tuan imam sanika aku.” — „No-si nan lokkita tu-dadi dea, anak-e, rame-po pĕngantan-kita."

Tu-ete lema, balangan-mo tuan kadi ke tuan imam lalo bakětoan. Dapat bale lala nan, bĕling-mo tuan kadi ke tuan imam: „Ao papu-e, ka suru aku ling dea-rea-mu, ia ku-sasai kau ke sĕmpu-sai-mu!" Ia-samong-mo ling lala nan: „E ku-heran tuan kadi ke tuan imam, 
u laten roepen, Mijne Heeren grootvader, mijnheer de kadi, mijnheer de imam, opdat $\mathrm{u}$ mij in het huwelijk verbindt met den Vader van Kĕbo-koening." De heer imam antwoordde: „Wie zou $\mathfrak{u}$ in het huwelijk durven verbinden met een laaggeborene, want $u$ heeft vele (en daardoor machtige) familie.” De Jonkvrouw antwoordde: „Gij behoeft (mij en mijne familie) niet te kennen, verbindt mij maar in het huwelijk!"

Het geschiedde, dat de heer imam en de heer kadi hen in het huwelijk verbonden. Daarna dronken zij koffie en na afloop daarvan namen de heer imam en de heer kadi afscheid. Om kort te gaan, zij gingen naar huis terug.

Toen het de gewone tijd was, ging de Jonker terug om naar de buffels te zien; hij zeide tot zijne vrouw : „Ik ga nu naar mijne buffeis zien!” Zij antwoordde: „Kom spoedig terug.” Hij ging recht door naar zijn eigen huis; daar sprak de oude edelman (zijn vader): „Waar zijt gij heen geweest, mijn zoon, dat gij nu twee nachten er niet geweest zijt ?” - „Ik ben naar mijn nicht gaan zien; toen ik bij haar huis kwam, zag ik plotseling dat zij schoon was, derhalve heb ik den heer imam en den heer kadi geroepen en hun bevolen mij in het huwelijk te verbinden.” — „Wat zeide je nicht, toen ze je zag ?” - „Zij kende mij volstrekt niet, want ik droeg een gescheurde kain en een gescheurde hoofddoek; toen zij mij gevraagd had: hoe heet gij, antwoordde ik: ik ben de Vader van Kĕbo-koening; elken dag gaf ik haar melk."

De edelman en zijne vrouw zeiden: ,Zoo kunnen wij niet te werk gaan, want wij zijn edellieden; wij moeten trouwen geheel zooals het behoort; het is de handelwijze van een laaggeborene, om het in 't geheim te doen." De edelman en zijne echtgenoote spraken voorts: „Ga niet hier of daar naar toe, mijn zoon, dan zal ik u geheel op de juiste wijze in het huwelijk doen verbinden, en nu den heer kadi en den heer imam roepen om de hand te vragen van uwe nicht." De Jonker antwoordde: „Waartoe, ik ben al getrouwd; de heer kadi en de heer imam hebben mij in het huwelijk (met haar) verbonden." „Zoo kunnen wij edellieden niet te werk gaan, mijn zoon, ons huwelijk moet in het openbaar zijn."

Om kort te gaan, mijnheer de kadi en mijnheer de imam gingen het huwelijksaanzoek verrichten. Toen zij bij de Jonkvrouw kwamen, zeiden de heer kadi en de heer imam: „O kleindochter, de edelman, uw oom, heeft ons gezonden, om u te verbinden met uw neef." De Jonkvrouw antwoordde: „He, ik verwonder mij over den heer kadi

D1. 92. 
rena tuan imam ke tuan kadi ka sanika aku; ada-ke tau basĕlaki dua kali, rena ada sělaki?” Ia-samong-mo ling tuan kadi : „Ulin dea-reamu, lampa, Bapa si Kĕbo-kuning nan; gampang-si, anak-e, lamin ngamok, tı-samate-mo, apa ulin nja-si baeng."

Ia-samong-mo ling lala'nan: „E lok gila tuan kadi, aku tau pina sĕlaki ulin-mo!” Dadi ia-samong-mo ling tuan kadi: ,Nongka patit, papu-e, tau marua sia lalo pina sělaki ulin!' Ia-samong-mo tuan kadi ling lala nan: „Tò-si kalako aku lampa; kuda to lelè nongka datang gita aku, kanjong ku-rango-mo; tò-mo kalako aku!"

Tu-ete lema, mule tuan kadi ke tuan imam lalo pĕri dea. Bĕling-mo dea nan: „Apa rungan, tuan kadi, tuan imam, ka ku-suru lalo nan ?” — „Ka-mo kĕdjulin-bĕling ke anak kalepe-kadji, samong kĕdjulin: Kuda, tuan kadi ka sanika aku ke tuan imam, to datang tuan kadi pěri aku, ada-ke tau basĕlaki clua kali, rena sĕlaki-ku ada: Bapa si Kĕbo-kuning.” Ia-samong-mo ling lalu nan: „Aku-si tuan kadi, tuan imam ka ia-sanika; ku-singin diri-ku Bapa si Kĕbo-kuning." Bĕlingmo dea nan: „Tu-sukat-po rame-rame, tuan kadi!”

Tu-ete lema, ia-kĕlek Bapa si Kĕbo-kuning, ia-lalo bawa ko bale lala nan: „Ta nja Bapa si Kĕbo-kuning; mu-roa-ke pina sĕlaki ling kau tau měnta rua?” Ěntek-mo Bapa si Kĕbo-kuning ko bao bale. Mutu ia-gita ling lala nan rua Bapa si Kĕbo-kuning, kasěrak lala nan, katakit ia-gita Bapa si Kĕbo-kuning. Ia-samong-mo ling tuan kadi : „Kuda bua mu-kasěrak, mu-katakit?” Dadi ia-samong ling lala nan tuan kadi: „Apa de mĕnta rua, ia-mo setan!”

Dadi bĕling tuan kadi: „Lok nasa akal, ku-sukat kau nan lampa, papu-e, ke papu-ku-si; lok dadi akal! Ba ta ling dea-rea-mu, kusukat kau rame-rame-po, kěrana boat(-kita) tu-dadi dea; mutu kusukat kau dunung nan, boat tau ulin; kelo aku ling papu-ku, lok 
en den heer imam, omdat gij mij getrouwd hebt; huwt iemand dan tweemaal een man, want ik heb toch een man?" De heer kadi antwoordde: „Een slaaf van uw adellijken oom, mijne dochter, is werkelijk die Vader van Kĕbo-koening; het is gemakkelijk, mijne dochter, als men amok maakt, kan hij gedood worden, want hij is een slaaf van uw oom."

De Jonkvrouw antwoordde: „He, zijt gij gek, mijnheer de kadi, ik ben het immers, die een laaggeborene tot man genomen heb." De heer kadi antwoordde: „Het paste niet, kleindochter, dat iemand als u een laaggeborene tot man ging nemen." De Jonkvrouw antwoordde hem: „Ik zie nu werkelijk 't voordeel er van in, (dat ik van hooge geboorte ben); waarom is 't nu, hoe lang ook is men niet naar mij komen zien, eerst nu ik volwassen ben (bekommert men zich om mij). Ik weet nu 't voordeel er van!"

Om kort te gaan, de heer kadi en de heer imam gingen terug en begaven zich naar den edelman. Deze zeide: „Wat voor een bericht is er, heer kadi, heer imam, die ik gezonden heb om (naar de Jonkvrouw) te gaan?”- „ „Uwe dienaars hebben gesproken tot uwe nicht, zij antwoordde: Hoe, mijnheer de kadi heeft mij, te zamen met den heer imam, in het huwelijk verbonden, en nu komt gij tot mij (met deze zaak); trouwt men tweemaal een man, ik heb immers een man, den Vader van Kĕbo-koening.” De Jonker antwoordde: „Ik ben het, dien mijnheer de kadi en mijnheer de imam in het huwelijk hebben verbonden; ik heb mij Vader van Kĕbo-koening genoemd." De edelman sprak: „Wij zullen hen nog met veel luister in het huwelijk verbinden!"

Om kort te gaan, men riep den Vader van Kĕbo-koening en bracht hem naar het huis van de Jonkvrouw en zeide: „Dit is de Vader van Kĕbo-koening; wilt gij een man, die er zoo uitziet, tot man nemen?" Hij ging naar boven in huis. Toen de Jonkvrouw zijn uiterlijk zag, gaf zij een gil en was bevreesd bij zijn aanblik. De heer kadi antwoordde: „Waarom gilt gij en zijt gij bevreesd?” De Jonkvrouw antwoordde den heer kadi: „Wat is hij, die er zoo uitziet, 't is alsof het een duivel is!"

De heer kadi sprak: „Wat vele listen zijn er gebezigd; ik heb u werkelijk, kleindochter, in het huwelijk verbonden, juist met mijn kleinzoon (den Jonker); wat was dat een voor den gekhouderij! $\mathrm{Nu}$, volgens het woord van uw oom, zal ik u nog met allen luister in het huwelijk verbinden, omdat dit de wijze van doen is van ons adellijken; toen $\mathrm{ik} u$ vroeger in het huwelijk verbond, was het de wijze van 
no ku-tò rua papu-ku, kenang kěre bërek, sapu berek."

Ia-samong-mo ling lala nan: „Tingka ku-tò rua, no-si ku-beang ěntek ko bao bale; dadi akal datang djual djadi; ta-mo ling dearea-ku, ku-turit-mo, sěbab ada-mo anak-ku.” Ia-pěngantan-mo ke rame-rame; suda ia-pěngantan, bĕling tuan kadi: „Ku-ngamit-mo aku, papu-e, apa to-mo tĕnga pětang.” Bĕling-mo lalu nan : „Balongsi, dea papu-e!" Mule tuan kadi ko bale.

Dapat ling siip-djaga, ia-gita sĕlaki; katawa lala nan, nongka iabada sĕlaki, ling dalam ate bae-si kațawa. Bĕling-mo sĕlaki: „Apa de mu-katawa?” Ia-samong ling sowai: „No-so-da!” Ling dalam ate sowai: „Nja-si lampa sĕlaki-ku ta, bakĕre berek, sapu berek, dadi no ku-tò rua."

\section{VII}

Ada sopo tau, ada anak sopo, singin anak Mĕndjai; pina rau. Dapat-mo ling masa, ia-roa-mo tanam pade. Bëling-mo bapa : „Lalomo mule ko desa, anak-e, ame mu-suru rik pade ina-mu, bau tělu dit!” Mule-mo Mĕndjai lako desa, dapat desa bĕling ko ina: „Ta ling bapa, ina-e : laga-mo rik bau tĕlu dit!" Ia-rik-mo ling ina pade, ia-kĕtoan-mo anak: „Pidan ia mu-ngasak?” Ia-samong-mo ling Mĕndjai: „Lamin ka-mo sědia sia-ngěrík, ku-bada-mo bapa, pang ano apa ia-roa tu-ngasak, ku-mule-mo datang bada sia."

Tu-ete lema, běling Mĕndjai: „Ta-mo ku-lalo ko rau, ina-e, ame ku-tulung bapa magar.” Běling ina: „Balong-si, anak-e, ame sěntara ku-nudja; ku-sarĕmin loto; ada-ke lok no tu-adjak tau, ia no tusĕdia sarea.” Bĕling-mo Mĕndjai : „Tutu-si ling-sia, ina-e; ta ku-lalo aku mule ko rau, ame ku-tulung bapa."

Mule-mo Mĕndjai, dapat rau, bĕling bapa: „Apa ling ina, Mĕndjai ?” Dadi ia-samong ling Mĕndjai : „Ta ling ina-ku, bapa-e : ta-mo 
doen van laaggeborenen; mijn kleinzoon (de Jonker) had mij misleid, zoodat ik hem niet herkende, gekleed met een gescheurde kain en hoofddoek."

De Jonkvrouw antwoordde: „Als ik geweter had, wie hij was, had ik hem niet boven in huis laten komen; derhalve was 't een list van hem om melk te komen verkoopen; nu zal ik opvolgen, wat mijn oom zegt, omdat ik met kind ben." Zij huwden dan met veel luister; daarna zeide de heer kadi: „Ik vraag verlof om heen te gaan, kleinkinderen, want het is nu middernacht." De Jonker sprak: „Goed, heer grootvader!” Mijnheer de kadi ging naar huis.

Vroeg in den morgen zag de Jonkvrouw haar echtgenoot; zij lachte, zonder iets tegen hem te zeggen, alleen bij haar zelf. Haar echtgenoot zeide: „Waarom lacht gij ?” Zijne echtgenoote antwoordde: „Nergens om,” Bij haar zelf dacht zij: „Dat is dus werkelijk mijn echtgenoot, hij had (vroeger) een gescheurde kain en hoofddoek, daarom herkende ik hem niet."

\section{VII}

Er was eens een man, die één zoon had, die Mĕndjai heette; zij bewerkten een ladang. Toen de geschikte tijd daarvoor gekomen was, wilde hij rijst planten. De vader sprak: „Ga terug naar het dorp, mijn zoon, zeg aan uw moeder, dat zij rijst moet uittreden, ongeveer de hoeveelheid van 3 dit's!" Mĕndjai keerde naar het dorp terug en aldaar gekomen, zeide hij tot zijne moeder: „Zoo zegt vader, moeder: treed eens ongeveer 3 dit's rijst uit!' De moeder trad cle rijst uit en vroeg toen aan haar zoon: „Wanneer wilt gij de rijst zaaien?” Měndjai antwoordde: „Als u klaar is met uittreden, zal ik het aan vader melden; op welken dag hij wil dat wij zaaien, daarvoor zal ik terugkomen, om het u te zeggen."

Om kort te gaan, Mĕndjai sprak: „Nu zal ik naar de ladang gaan, moeder, om vader te helpen een omheining te maken." De moeder zeide: „Goed, mijn zoon, dan zal ik ondertusschen stampen om gestampte rijst bijeen te brengen; zouden wij toch geen menschen uitnoodigen (om te helpen), dan kunnen wij niet alles klaar krijgen." Mĕndjai sprak: „U heeft wel gelijk, moeder; nu ga ik naar de ladang terug, om vader te helpen."

Mĕndjai ging; toen hij op de ladang gekomen was, zeide de vader: „Wat heeft uwe moeder gezegd, Mĕndjai?” Mĕndjai antwoordde: 
ku-ngĕrik.” Dadi běling bapa: „Ka pida dit ngěrik ina-mu ana?” Ia-samong-mo ling Měndjai : „Kuda, ling-sia tělu dit, tělu dit-si iarik ling ina. Dadi ling ina: lamin ada ano balong bulan balong ia-roa ling bapa-mu ia tu-ngasak, mule datang bada aku, aku ku-sarěmin loto-si !"

Dadi tu-ete lema, ada-mo ano bulan ia-roa ling bapa ia ngasak, bĕling-mo ko Mĕndjai: „Lalo-mo mule, anak-e, bada ina-mu, pang ano djĕmat tu-ngasak!" Mule Měndjai lako desa; dapat desa iakětoan ling ina: „Apa ling bapa-mu, Měndjai?” — „Dadi ling bapaku ano djěmat ia-roa ngasak.” Bĕling-mo ina: „Lamin měnan-si, anak-e, lalo-mo adjak dĕngan-mu!” Bĕling-mo Mĕndjai: „Bau pida tau ku-adjak, ina?" Ia-samong-mo ling ina: „Me lok, ame dadi sa-ng-ano ngasak, ame na lěga tu-rugi ?"' Ia-samong-mo ling Měndjai : „E ina-e, ěmpat-pulu tau tu-adjak, nan-po bau suda sa-ng-ano.”

Bĕling-mo Mĕndjai : „Kawan-ke loto-sia ia kakan ling tau ĕmpatpulu?” Ia-samong-mo ling ina: „Kawan-si, anak-e.” Bĕling-mo Mĕndjai ko ina: „Apa ia djangan tau ame na tu-kangila?” Ia-beangmo pipis ling ina, tělu real : „Ma-mo lalo běli bědis, ame tu-sěmĕle!” Ia-samong-mo ling Mĕndjai: „Balong-si, ina-e.” Lalo Mĕndjai bĕli bědis; dua bĕdis ia-bawa mule. Dapat bale Mĕndjai, bĕling-mo ina: ...Me-po pang tu-samasak djangan, anak-e?” Ia-samong-mo ling Mĕndjai: „Pang rau-mo, ina-e, tu-samasaki ; mè bae-mo sia-samasak ling desa, ame djaga tu-balangan.

Dapat siip-djaga, balangan sarea ko rau; dapat rau, sĕmĕle-mo bĕdis, tau pĕno lalo ngasak. Tĕpang mĕnggĕrib bue ngasak. Tu-ete lenia, ngamit-mo sarea tau pěno ka ia-adjak nan, mule sarea ke ina Mĕndjai.

Tu-ete lema, balong tumong pade, tinim, lene, balong tumong sarea. Dapat-mo ling masa, rabua-mo lene, rabua-mo tinim. Bělingmo bapa Mĕndjai : „Lalo-mo ete djaran-mu djaga, anak-e, ame muboko lene, tinim, sĕdĕka lako sarea tau ka tu-adjak nan!" 
„Vader, moeder zeide: aanstonds ga ik aan het rijst uittreden." De vader zeide: „Hoeveel dit's heeft uw moeder uitgetreden?” Měndjai antwoordde: „Hoe, gij zeidet, dat het 3 dit's moesten zijn en 3 heeft moeder ook uitgetreden. Toen zeide moeder: als 't een goede dag en de goede maand is, dien uw vader wil hebben om daarop rijst te zaaien, kom dan terug om 't mij te zeggen, ik zal ook gestampte rijst bijeen brengen."

Om kort te gaan, toen er een dag van de maand was, dien de vader hebben wilde om rijst te zaaien, zeide hij tot Mĕndjai: „Ga terug mijn zoon, en zeg aan uwe moeder, dat wij Vrijdag zullen zaaien." Měndjai keerde naar het dorp terug; toen hij daar gekomen was, vroeg zijn moeder hem: „Wat heeft uw vader gezegd, mijp zoon?” - „Mijn vader heeft gezegd, dat hij op Vrijdag de rijst wil zaaien.” De moeder sprak: „In dat geval, mijn zoon, ga dan uw makkers uitnoodigen!” Mĕndjai zeide: „Hoeveel menschen zal ik ongeveer uitnoodigen, moeder?” De moeder antwoordde: „Hoe moet het, dat wij in één dag zaaien, opdat wij niet te veel onkosten hel-ben?” Mĕndjai antwoordde: „Moeder, wij zullen 40 menschen uitnoodigen, dan pas kan het in één dag afgeloopen zijn."

Hij zeide (nog): „Heeft u voldoende gestampte rijst voor 40 menschen om te eten?” De moeder antwoordde: „Voldoende, mijn zoon!" Mĕndjai sprak tot zijne moeder: „Wat zal er tot toespijs voor de lieden zijn, dat wij niet te schande komen?" De moeder gaf hem geld, ter waarde van 3 rijksdaalders: „Ga een geit koopen en laten wij die slachten!" Mĕndjai antwoordde: „Goed, moeder!" Mĕndjai ging geiten koopen; 2 geiten bracht hij naar huis. Toen hij thuis kwam, zeide zijne moeder: „Waar zullen wij het vleesch koken, mijn zoon?” Mĕndjai antwoordde: „Op de ladang zullen wij het gaar maken; de rijst alleen moet gij hier in het dorp gaar maken, dan kunnen wij vroeg op weg gaan."

Toen het vroeg in den morgen was, gingen allen naar de ladang: aldaar gekomen slachtten zij de geiten en de lieden gingen de rijst zaaien; juist op den tijd van het gebed bij zonsondergang was 't afgeloopen. Om kort te gaan, alle lieden, die gevraagd waren om te helpen, namen afscheid en gingen (naar het dorp) terug, alsook de moeder van Mĕndjai.

Om kort te gaan, de rijst groeide mooi op en de komkommers en de meloenen, alles groeide mooi op. Toen het de tijd er voor was, droegen de meloenen en de komkommers vrücht. De vader van Mĕndjai zeicle (toen): „Ga vroeg uw paard halen, mijn zoon, en belaad 
Tu-ete lema, mule-mo Mĕndjai, boko lene, boko tinim; dapat bale, bĕling-mo ko ina Měndjai : „Sia-ete dulang, ina, isi tinim ke lene ta; ka suru aku bapa sěděka lako sarea tau ka tu-adjak nan!” Ete dulang ina Mĕndjai, ia-olo-mo tinim, lene; ia-bawa-mo lako bale tau ka ia-adjak nan. Bĕling-mo tau ka ia-adjak nan: ,Tinim me ta ke lene me ta?" Ia-samong-mo ling ina Mĕndjai: „Ade ka mu-tanam ling kau, nan-si rabua.” Ia-samong-mo ling tau: „Alhamdu l'illah, gantjang rabua!"

Dadi, tu-ete lema, ia-suru-mo mule Měndjai lako rau. Dapat rau, nonda loto bapa. Běling-mo bapa: „Kĕle mu-kangompa, lalo-mo mule, anak-e, tungan djaran-mu, lalo ete loto!" Ia-tungan-mo djaran Měndjai, mule; dapat rawi, no-po-ka lalo rabalik ko rau, bapa panas tian; dapat měnggěrib, ada-mo Měndjai pang rau.

Běling-mo bapa: „Kuda mu-lè, Měndjai ?” — „Ku-dapat bale, bapa-e, sakit ina; aku ku-nudja; bua lè ku-datang." Dadi bĕling-mo bapa: „Tĕrang-si-ke ina, lok mu-gita panjakit?” Ia-samong-mo ling Mĕndjai: „E bapa-e, ku-kasakit aku ta, lamin ta-si lok tau, kudatang ko rau, rena ina sakit.” Běling-mo bapa: „Lalo-mo mule, anak-e, lamin těrang-mo ina-mu, mu-datang-mo tulung aku ěntok pade ta, lěga kědit kakan pade, anak-e!” Bĕling Měndjai: „Balong-si, bapa-e."

Dapat desa Mĕndjai, nangis. Bĕling ina: „Kuda bua mu-nangis, Mĕndjai?” — „Ka mate bapa, ina-e, ka ia-sit ling ular, nan nja bua ku-nangis.” — „Ba te-mo tu-lalo, anak, ame tu-adjak isi měsigit!” Ia-samong-mo ling Mĕndjai: „Ka-mo ku-talat bapa-ku, nan nja bua kut-mule ta!" Ia-samong-mo ling ina: ,Alhamdu l'illah, lamin ka-mo mu-talat bapa-mu, anak-e!” Bĕling-mo Mĕndjai: „Pidan tuhasĕdĕka?” Ia-samong ling ina : „Puan-mo, anak-e.” Bĕling Mendjai: ..Nawar-mo, ina, apa lema ku-lalo ko rau, pade, lĕga kĕdit boat 
het met meloenen en komkommers, als een gift voor al de lieden, die wij gevraagd hebben om ons te helpen!"

Om kort te gaan, Mĕndjai ging terug (naar het dorp), terwijl hij op het paard meloenen en komkommers medevoerde; toen hij thuis kwam, zeide hij tot zijne moeder : „Neem schenkbladen, moeder, en doe daarop deze komkommers en meloenen; vader heeft mij gezonden om ze te schenken aan al de lieden, die wij gevraagd hebben, om ons te helpen!" De moeder van Mĕndjai nam schenkbladen en legde daarop de komkommers en meloenen; toen werden zij gebracht naar de huizen van hen, die gevraagd waren om te helpen. Deze zeiden: „Wat zijn dit voor komkommers en meloenen?" De moeder van Mĕndjai antwoordde: „Dat, waaraan gij (geholpen) hebt, om te planten, heeft vrucht gedragen.” Zij antwoordden: „Gelukkig, zij dragen snel vrucht."

Om kort te gaan, Mĕ̀ndjai werd bevolen naar de ladang terug te gaan. Toen hij daar aankwam had zijn vader geen gestampte rijst meer. Hij zeide: „Al zijt ge moe, ga toch naar huis, mijn zoon, ga op uw paard zitten en ga gestampte rijst halen!' Mĕndjai steeg te paard en ging naar huis; toen het namiddag werd, ging hij niet meer naar de ladang terug, zoodat zijn vader honger kreeg; eerst tegen zonsondergang was Mĕndjai op de ladang.

Zijn vader sprak: „Waarom zijt gij zoo lang uitgebleven, Mĕndjai?" - „Toen ik thuis kwam, vader, was moeder ziek; toen ben ik aan 't rijst stampen gegaan; daarom kom ik zoo laat." Toen sprak de vader: „Was uwe moeder nogal goed, naar gij de ziekte zaagt?” Mĕndjai antwoordde: „Vader, ik zal ziek worden, als 't zoo met ons voort moet gaan en ik (telkens) naar de ladang moet komen, dewijl moeder ziek is.” De vader zeide: „Ga naar huis, mijn zoon, en als uwe moeder beter is, kom dan terug om mij te helpen op de rijst te passen, want er zijn vele rijstvogels, die de rijst eten, mijn zoon!" Mĕndjai sprak: „Goed, vader!”

Toen hij in het dorp kwam, weende hij. Zijne moeder sprak: „Waarom weent gij, Mĕndjai ?” — „Mijn vader is gestorven, moeder, hij is door een slang gebeten, daarom ween ik.” - „Welaan, laat ons gaan, mijn zoon, om (iemand van) het moskeepersoneel te vragen om mede te gaan!” Mĕndjai antwoordde: ..Ik heb vader al begraven, daarom kom ik terug.” De moeder zeide: „Lof zij Allah, als gij uw vader begraven hebt, mijn zoon!” Měndjai sprak: „Wanneer zullen wij een lijkmaal geven?” De moeder antwoordde : ,Overmorgen, mijn zoon!” Mĕndjai zeide: „Laat 't morgen zijn, moeder, dan kan ik 
kakan!” Ia-samong-mo ling ina: „Balong-si, anak-e, lalo-mo bĕli bědis, ame tu-basěděka nawar!" Ia-beang pipis Mĕndjai, balanganmo Mĕndjai lalo bĕli bědis.

Tu-ete lema, ada bawa bědis Mĕndjai; bĕling ina: „Sĕmĕle-mo, anak-e, ame lema tu basěděka!"' Tu-ete lema, lalo kĕlek imam, pangulu; datang-mo sarea. Е̌ntek-mo ko bao bale, ia-kĕtoan-mo ling imam: ,Sělamat pade-ke basědĕka ta ?” Bĕling-mo ina Mĕndjai : „E tuan imam-e, ka mate Bapa si Mĕndjai, ka ia-sit ling ular pang rau!" Bĕling-mo tuan imam: „Nongka datang bada tau ka mate bapa Měndjai ; tingka ka bada aku, ku-lalo-si."

Tu-ete lema, djira mangan, mule-mo tuan imam, tuan pangulu ko bale. Bĕling-mo Měndjai ko ina: „Isi ěmpa bĕdis ko pamongka, ia ku-bawa ko rau, ame ada djangan ku-mangan pang rau, ina-e!" Iaisi-mo pamongka ling ina, goreng. Tu-ete lema, balangan-mo Mĕndjai ko rau; dapat luar pagar, ia-sangera mata ke tjabe, nangis lis ai mata. Dapat bale rau, běling bapa Měndjai: „Kuda bua mu-nangis, Mĕndjai?” — „Ka mate ina, bua ku-nangis, bapa-e.” Bĕling-mo bapa: „Te-mo tu-mule, anak-e, ame tu-talat ina-mu, nanta!” Iasamong ling Mĕndjai: „Mutu ku-dapat bale, bapa-e, ka-mo mate ina, ia-talat-mo ling imam, pangulu; ta nja goreng ku-bawa, ka-mo ku-sědĕka ina-ku.” — „Alhamdu l'illah, anak-e,” ling bapa.

Tu-ete lema, bĕling-mo bapa Mĕndjai: „Lalo-mo mule, anak-e, ame mu-nudja, apa no monda loto-kita." Mule-mo Mĕndjai lako desa ; dapat desa Mĕndjai, ia-ěntek ko bale, ia-sangera mata ke tjabe. Bĕling ina: „Kuda mu-nangis, Mĕndjai?” Ia-samong-mo ling Mĕndjai: „Bua ku-nangis, ina-e, ku-kangompa ĕntok rau; pĕtang bawi kakan pade, ano kĕdit kakan pade. Ada sopo tau tulung aku, ta ling bĕling ke aku: e Mĕndjai-e, tingka mu-roa pina aku bapa, ku-tulung-mo kau ěntok rau-mu. Dadi ku-bĕling-mo aku: lamin roa ina-ku, ba ku-bada-mo kau era." Dadi bĕling-mo ina Měndjai: 
spoedig weder naar de ladang gaan, want bij de rijst zijn vele rijstdieven, die er op azen!” De moeder antwoordde: „Goed, mijn zoon, ga een geit koopen, dan kunnen wij morgen het lijkmaal geven." Zij gaf aan Mĕndjai geld, deze ging een geit koopen.

Om kort te gaan, Mĕndjai had een geit medegebracht; toen zeide zijne moeder: "Slacht haar mijn zoon, dan kunnen wij snel het lijkmaal geven." Om kort te gaan, men ging den imam en den pangulu roepen; zij kwamen beiden. Toen zij boven in huis waren gekomen vroeg de imam: „Wordt er nu feest gevierd voor het slagen van de rijst?” De moeder van Měndjai zeide: „Ach, mijnheer de imam, de vader van Mĕndjai is gestorven, doordat een slang hem op de ladang gebeten heeft.” De heer imam zeide: „Niemand heeft mij gemeld, dat de vader van Mĕndjai gestorven is; indien men 't mij gezegd had, was ik er ook heen gegaan."

Om kort te gaan, na afloop van het eten, gingen de heer imam en de heer pangulu naar huis. Mĕndjai zeide toen tot zijne moeder : „Doe het (overgeblevene) geitenvleesch in een pot, dan neem ik het mede naar de ladang, dan heb ik daar wat vleesch te eten!" De moeder deed het in de pot en braadde het. Om kort te gaan, Mĕndjai ging naar de ladang; aan de buitenkant van de omheining gekomen, makkte hij zijne oogen rood met peper, zoodat hij weende en zijne tranen vloeiden. Toen hij in de woning op de ladang kwam, zeide zijn vader : „Waarom weent gij, Mĕndjai?” — „Moeder is gestorven, daarom ween ik, vader.” De vader zeide: „Welaan, laten wij naar huis gaan, mijn zoon, om uwe arme moeder te begraven!” Mĕndjai antwoordde: „Toen ik thuis kwam, was moeder al gestorven en begraven door den imam en pangulu, hier heb ik gebraden vleesch medegebracht, ik heb al een lijkmaal voor moeder gegeven.” - „Lof zij Allah", zeide de vader.

Om kort te gaan, de vader van Mĕndjai sprak: „Ga naar huis, mijn zoon, en stamp rijst, want wij hebben geen gestampte rijst." Mĕndjai keerde naar het dorp terug; aldaar gekomen, ging hij naar boven in huis, en maakte zijn oogen rood met Spaansche peper. Zijn moeder zeide: „Waarom weent gij, Mĕndjai?” Hij antwoordde: „Daarom ween ik, moeder, omdat ik moede word van het bewaken van de ladang; 's nachts vreten de varkens de rijst op, overdag doen het de rijstdiefjes. Er is iemand die mij geholpen heeft en dit heeft hij tot mij gezegd: Měndjai, als gij mij tot uw vader wilt maken, dan zal ik u helpen in het bewaken van uw ladang. Toen heb jk gezegd: als mijne moeder het wil, dan zal ik het a zeggen." Toen 
„Lamin nan-po ling-kau, anak-e, balong-si, ame ada tau tulung kau ěntok rau."

Mule-mo Mĕndjai lako rau; dapat rau, ia-sangera mata ke tjabe. Bĕling bapa : „Kuda mu-nangis, Měndjai ?” — „Ku-kangompa nudja, bapa-e; ada sopo tau ka tulung aku nudja: tingka roa aku ling bapa-si, Mĕndjai, no susa loto; mu-datang, mu-ete loto; no-mo munudja kau, Měndjai-e; nan ling běling, bapa-e." Ia-samong ling bapa: „Lamin nan-po lok, anak-e, pědi kau, ku-roa-si.” Bĕling Mĕndjai : „Ta ling tau ana, bapa-e: bakuris, nan-po ku-roa bapa-mu, Měndjai-e.” -_ „Lamin nan-po ling-kau, anak-e, tu-bakuris-mo.”

Mule Mĕndjai lako desa; dapat bale, bĕling ko ina: „Ta ling tau ana, ina-e: ku-roa-si ina-mu, Mĕndjai-e, bakuris dunung ina-mu, nan-po ku-roa.” Bĕling-mo ina Mĕndjai : „Lamin nan-po lok, anak-e, pědi-kau, ku-bakuris-mo." Tu-ete lema, rabalik lako rau Mĕndjai; bĕling-mo bapa: „Apa ling ka samong kau?” — „Roa-si bakuris, bapa-e; dapat pětang hĕmis, pukil balu, mule-mo ko desa, ame tunika!"

Dapat ling pětang hĕmis, pukil balu, mule ko desa bapa Mĕndjai ; ia-olo pang bale lin. Bĕling-mo bapa Mĕndjai: „Kanè ko bale-kita, kĕme anak?” - „Nan pang tau sowai àna pang bale-kita; suda sianika pang ninta, tu-bawa sia ko bale." Tu-ete lema, lalo Mĕndjai kĕlek imam, pangulu; datang-mo imam, pangulu, ia-sanika-mo; turin-mo imam, pangulu, suda ia-sanika; ia-bawa-mo ling tau pĕno bapa Mĕndjai lako bale; dapat bale nan, basai-mo ina ke bapa.

Dapat siip-djaga, ia-gita ling bapa Mĕndjai ina: „Lok tjilaka Mĕndjai, ka sukat aku ke kau-si lampa!” Bĕling-mo ina Mĕndjai: ..Nan ling anak-mu si Mĕndjai, bada aku: bapa ka mate, ia-sit ling ular; nan nja ku-basĕděka, 1)awa ĕmpa bĕdis lako rau.” Bĕling bapa Mĕndjai: „Dapat rau, nangis; dadi ku-běling: kuda bua mu-nangis, 
zeide de moeder van Mĕndjai: „Als gij zoo spreekt, mijn zoon, dan is het (mij) goed, opdat er u iemand helpt bij het bewaken van de ladang."

Měndjai ging weer terug naar de aanplanting; aldaar gekomen, makkte hij zijne oogen rood met Spaansche peper. Zijn vader zeide: „Waarom weent gij, Mĕndjai?” - „Ik ben moede van het rijststampen, vader; er was iemand, die mij daarbij geholpen heeft (en die zeide): als uw vader mij hebben wil, Mĕndjai, zult ge geen moeite meer hebben met de gestampe rijst; als gij komt neemt gij ze maar; gij, Mĕndjai, behoeft niet meer te stampen; zoo sprak zij, vader." De vader antwoordde: „Als het zoo is gesteld, mijn zoon, wil ik wel uit medelijden met u." Mĕndjai sprak: „Zoo heeft die vrouw daar gesproken, vader: eerst moet hij (zijn haar) afscheren, dan wil ik uw vader hebben, Mĕndjai!” — „Als gij zoo spreekt, mijn zoon, zullen wij ons 't haar afscheren."

Mĕndjai keerde naar het dorp terug; te huis gekomen zeide hij tot zijne moeder : ,Zoo zegt de man daar moeder: ik wil uw moeder wel hebben, Mĕndjai, maar eerst moet zij zich het haar afscheren, dan wil ik haar hebben!” De moeder van Mĕndjai zeide: „Als 't zoo is, mijn zoon, zal ik uit liefde voor u mijn haar afscheren." Om kort te gaan, Měndjai keerde naar de ladang terug; de vader zeide : „Welk antwoord heeft zij u gegeven?” — ,Zij wil; vader, nu gij het haar afgeschoren hebt; op den avond voor Donderdag om 8 uur moeten wij teruggaan naar het dorp, voor de huwelijksvoltrekking."

Op dien avond, om 8 uur, keerde de vader van Mĕndjai naar het dorp terug; Mĕndjai deed hem zijn intrek nemen in een vreemd huis. De vader sprak: „Wij moesten maar naar ons huis gaan, is 't niet mijn zoon?” - „Daar in ons huis bevindt zich de vrouw; als gij hier gehuwd zijt, zullen zij u te huis brengen." Om kort te gaan, Mĕndjai ging den imam en den pangulu roepen; zij kwamen en voltrokken het huwelijk; na afloop daarvan verlieten zij het huis en de menigte bracht den vader van Mĕndjai naar huis; aldaar vereenigden zich de nioeder en de vader.

Toen het vroeg in den morgen was, zag de vader van Mĕndjai de moeder: „Wat een ongelukskind is die Mĕndjai, daar heeft hij waarachtig mij met u doen trouwen!” De moeder van Mĕndjai zeide: „Uw zoon Mĕndjai heeft mij gezegd: vader is gestorven doordien een slang hem gebeten heeft; daarom heb ik een lijkmaal gegeven en hij heeft (overgebleven) geitenveelsch naar de ladang gebracht." De vader van Mĕndjai sprak: ,Toen hij op de ladang kwam, weende 
Mĕndjai; ka mate ina, ia ktt-basědĕka nan; lĕga akal Mĕndjai, ka sukat akı ke kau-si; maeng tı-samate Mĕndjai, sangila tau!” Bĕlingmo ina: „Na samate anak-mu, nanta!” Dadi běling bapa: „Maeng kt1-ptıkil bae-mo!” Dadi ia-samong ling ina: „Ampar, na-mo gĕras!”

Dapat rau, ada Mĕndjai pang rau; ia-apan ling bapa, ia-roa ampar, barari Měndjai. Batĕmong ke tau lemar ěmpa, bĕling Mĕndjai: „Barari lema, tau ngamok, lěga tau ia-samate!” Ia-bolang ěmpa tau nan, ia-ete ling Mĕndjai, ia-lemar. Dapat ola, batěmong ke bapa. Bĕling bapa Mĕndjai: „Me ka pang mu-bawa ěmpa, Měndjai?” Iasamong ling Mĕndjai: „Ka ku-lalo mantjing, bapa-e.” Ia-bawa-mo mule tĕris ko rau, balangan dua ke bapa.

Dapat rau, běling-mo bapa : „Me pang ka mu-mantjing, Mĕndjai ?” — „Ada batu rango ling sisi lit ana.” — „Apa impan mu-mantjing ?" — „Punti sangradja.” Ia-běli-mo ling bapa punti sangradja tĕlı rimpi. Bĕling-mo Mĕndjai: „Ta ku-lalo dunung aku, bapa-e, pina pang sia-tokal ling bao batu ana, ame njaman sia-tokal!" Suda iapina ling Mĕndjai pang tokal bapa, turin Mĕndjai, tama ko dalam batu.

Tu-ete lema, dapat-mo batu nan bapa, tokal pang bao batu, ia-ngo Mĕndjai, nonda Mĕndjai; ia-ngo, nonda njamong. Bĕling bapa: ,Me ka lako binatang ta ?” Ia-anti ling bapa, nonda. Bĕling-mo bapa mesa-mesa: „Ka bada aku Měndjai, olo sě-pa sakali impan.” Ia-satěri pantjing, ia-betak ling Mĕndjai ling dalam batu nan, ia-kakan punti ling Mĕndjai. Mutu gěnap tělu kali ia-satěri pantjing, barĕngo bapa Mĕndjai: „O Měndjai!” ia-ngo ling bapa, nonda njamong Mĕndjai. Bĕling bapa mesa-mesa: „Me lok mantjing Mĕndjai ta; aku tĕlu kali-mo ku-satěri pantjing-ku, běru dapat dalam ai, ia-betakmo ling ĕmpa, ku-betak ling aku, no monda impan, ěmpa nonda roa kěna; tjilaka pantjing ta!"

Tu-ete lema, bue punti tĕlu rimpi, ia-pina impan, turin bapa, njĕlok; barari Mĕndjai ola satue, batěris lako rau Mĕndjai, ia-uleng pagar. 
hij ; ik zeide daarom: waarom weent gij Mĕndjai ; (hij zeide:) moeder is gestorven, ik zal 't lijkmaal geven; het is al te erg met Mĕndjai, hij heeft mij met u doen trouwen; vooruit, laten wij hem dooden, hij heeft ons te schande gemaakt!” De moeder sprak: „Dood je jongen niet, dien arme!” Toen zeide cle vader: „Welaan, laat ik hem dan alleen een pak slaag geven!" De moeder antwoordde: „Als gij hem slaat, sla dan niet te hard!"

Toen de vader op de ladang kwam, was Mĕndjai aldaar; zijn vader zette hem achterna, omdat hij hem wilde slaan; Mĕndjai ging op den loop. Hij kwam iemand tegen, die visch droeg, hij zeide: „Vlucht snel, er is een amok-maker, hij heeft al vele menschen gedood!" De man wierp de visch weg, Mĕndjai nam ze op en droeg ze voort. Onderweg kwam hij zijn vader tegen. Zijn vader zeide: „Van waar hebt ge visch medegebracht, Měndjai?” Deze antwoordde: „Ik ben gaan hengelen, vader!” $Z$ ijn vader nam hem mede rechtstreeks naar de ladang terug, hij ging te zamen met zijn vader.

Op de ladang gekomen zeide de vader: „Waar hebt gij gehengeld, Mĕndjai?” — „Er is een groote rots aan den zeekant.” — „Met wat voor aas hebt gij gehengeld?” — „Met pisang radja.” De vader kocht drie kammen pisang radja. Mĕndjai sprak: „Ik zal nu vooruit gaan, vader, om een zitplaats voor u te maken daar op de rots, dat gij gemakkelijk kunt zitten." Nadat Mĕndjai een zitplaats voor zijn vader gemaakt had, daalde hij af en ging in (een holte) van de rots.

Om kort te gaan, toen de vader op de rots kwam, ging hij daar boven op zitten, hij riep Mĕndjai, maar deze was er niet; hij riep, maar er kwam geen antwoord. De vader zeide: „Waar is dat beest heengegaan?" De vader wachtte op hem, maar hij was er niet. De vader zeide toen in zijn eentje: ,Mĕndjai heeft mij gezegd, doe een heele pisang tegelijk als aas aan den hengel." De vader wierp den hengel uit; Mĕndjai, die in (de holte) van de rots was, trok eraan en at de pisang op. Toen de vader den hengel volle 3 maal had uitgeworpen, begon hij te roepen: „Ho, Mĕndjai”, riep hij, maar Mĕndjai antwoordde niet. De vader sprak in zijn eentje: „Hoe heeft Mĕndjai toch gehengeld; ik heb 3 maal den hengel neergelaten, zoodra hij in 't water komt, trekt een visch er aan, als ik hem optrek is het aas er niet meer aan, maar de visch wil zich niet laten vangen; dit is een ongelukshengel!"

Om kort te gaan, toen de 3 kammen pisang, die tot aas zouden dienen, op waren, ging de vader naar beneden en dook in het water; Mĕndjai liep snel de andere kant uit rechtstreeks naar de ladang en 
Mule bapa lako rau, ia-roa pukil Mĕndjai; barĕngo bapa pang bale: ..O Měndjai!” ia-ngo. Njamong Mĕndjai. Běling bapa: „Ma, bada kau, lako ta!" Lalo Mĕndjai, ia-pěri bapa. Bapa ka ěnti kaju iakenang pukil Mĕndjai. Kĕtoan-mo ling bapa: „Lĕga akal lampa Mĕndjai ta, suru aku lalo mantjing, no-so-da nja pang ana!” - „E ka ku-mule, bapa-e, ku-buja sia, nongka ku-batěmong ke sia pang ola.” Běling-mo lapa : „Dadi lěga akal-mu kau ta!”

Běling Měndjai: „E bapa-e, tingka nongka ku-mule datang buja sia, bue pade ta ling kĕbo, pagar no-po-ka suda ku-satĕrang, ka iasabongkas ling kĕbo.” Ia-samong-mo ling bapa: „Te tu-lalo gita ke aku, lamin nongka bongkas pagar ana, kut-samate kau, Mĕndjai-e; legga-mo mu-akal aku, mu-sukat aku ke ina-mu, suru aku lalo mantjing impan punti, impan bue, ěmpa no-so-da, kau no-so-da, maeng ku-ěnti ima-mu, kěna mu-bilin aku barari, te-mo tu-lalo gita pagar ana!" Bĕling-mo Měndjai: „Ma-mo sia-ěnti ima-ku, te-mo tu-lalo!” Iabawa-mo ling bapa lako pagar, ka ia-sěpan bongkas. Mutu ia-gita ling bapa masi bongkas, ia-olas anak: „E nanta Mĕndjai, djangi ia kupukil kau, ku-gita pagar ta tutu-si bongkas, ba ta no-mo pukil kau, anak-e!"

\section{VIII}

\section{Bismi-llāhi-rraḥmāni-rraḥīm.}

Kewa singin Allah ta ${ }^{\mathrm{c}}$ ala bae-si ku-samula batja kitab ta; diri bae-si nènè ngere amak pang dalam desa dunia ta ke ampo ngere djina rapaměndi pang dalam desa acherat ana. Alhamdu li-llāhi rabbil'ālamīn, tĕgas-na: sarea pudji-pudji nan tantu lako Allah ta ${ }^{\mathrm{c}}$ ala, nènè parenta sarea 'alam ta; zva-l'ạkibatu li-lmuttakîn, ke katěrang acherat nan uman tau takit lako Allah ta'ala; (wa-)sșalātu wassalāmu 'alā sayyidinā Muhammadin sayyidi-l'anbiyā̄i wa-lmursalīn, ke paměndi Allah ta ${ }^{\mathrm{c}}$ ala kewa pasalamat-diri nènè kita Allah ta ${ }^{\mathrm{c}}$ ala lako pangulu-kita nabi Muhanmad, ja nan-si pangulu sarea nabi ke

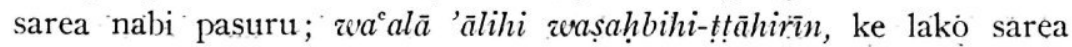


maakte eene opening in de omheining. De vader keerde terug naar de ladang en wilde Mĕndjai slaan; hij riep in de hut aldaar: „Ho, Měndjai”, riep hij. Mĕndjai gaf antwoord. De vader sprak: „Kom, ik zal u wat zeggen, hierheen!" Mĕndjai begaf zich tot zijn vader. Deze hield een stuk hout in de hand om Mĕndjai daarmede te slaan. De vader vroeg: „Het is werkelijk al te erg met Mĕndjai, hij laat mij gaan hengelen, maar hij was daar niet, (hoe komt dat?)” — ,Wel, ik ben teruggekeerd, vader, ik zocht $u$, maar ik ontmoette u niet op weg." De vader zeide: „De zaak is dat je mij wat wijs maakt.”

Měndjai sprak: „Vader, als ik niet teruggekeerd was, om u te zoeken, zou al de rijst weg zijn door de buffels, ik heb de omheining nog niet geheel in orde gemaakt, nadat de buffels haar vernield hadden.” De vader antwoordde: ,Welaan, ga gij met mij er naar zien, als de omheining niet vernield is, dood ik $u$, Mĕndjai; gij hebt mij erg voor den mal gehouden, gij hebt mij met uw moeder doen trouwen, hebt gemaakt, dat ik ging hengelen met pisang als aas en $n u$ is het aas op, maar één visch heb ik niet, gij waart er niet, vooruit, ik zal u bij de hand houden, gij mocht soms hard van mij wegloopen, vooruit, laten wij naar de omheining gaan zien!" Měndjai sprak: „Welaan, neemt u mij bij de hand, vooruit, laat ons gaan!' Zijn vader bracht hem bij de heining, die hij gezegd had, dat vernield was. Toen de vader zag, dat zij nog stuk was, streelde hij zijn zoon: „Och, mijn goede Měndjai, ik was voornemens om je te slaan en ik zie, dat de omheining werkelijk vernield is, nu zal ik je niet meer slaan, mijn zoon!"

\section{(Vervolg van VIII)}

sanak-bangsa-diri ke lako sarea sake-sake-diri nabi Muhammad sutji sarea diri nan.

'Ammā ba'du fahādihi risālatun muchtașaratun wasammaytuhā

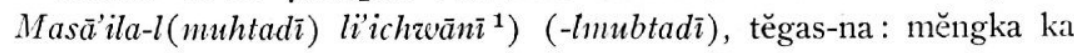
djira nan, ta-mo nja sa-nompo kitab ke ku-singin nja „Masā'ila (-lmuhtadī) li'ichwānī(-lmubtadī)", těgas-na: sarea mas’al(ah) basatělit ola ruris lako sarea sanak-sowai-sĕlaki-ku tau běru ${ }^{2}$ ) baladjar.

Ta-mo nja sa-nompo fașal pang basaněmpas pangkĕling 'īmān ke ${ }^{3}$ )

1) Zoo volgens de vertaling; het ms. van Jonker heeft li-l'ichwāni, de Ma!. mss. lịichwāni, wat in ieder geval fout is.

2) Zoo te lezen; ms. : bĕri.

3) Ms. : pangkěling ke 'imān.

DI. 92. 
'islām ke 'iḥsān ke tawḥīd kewa ma rifat ke pangkĕling sjahādat barĕma ke sarea farḍu-nja ke sarea rukin sjahādat ke sarea sjarạ̣ șah sjahādat ke sarea sampurna sjahādat ke sarea anung sarusak nja, sjahādat; ke i-saněmpas sarea rukin 'īmān mudjmal ke rukin 'īmān mufașạal, sěrta sarea farḍu pang dalam-na ke sarea sjaraț șạ pang dalam-na ke sarea sampurna pang dalam-na ke sarea anung sarusak nja; ke i-saněmpas sarea farḍu 'istindjā' ke sarea sjaraṭ-na, ke sarea farḍu maning wãdjib ${ }^{1}$ ); ke i-sanĕmpas sarea sjaraț dunung ke wuḍī' $\left.{ }^{2}\right)$ ke sarea anung sarusak wuḍū'; ke i-saněmpas sarea sjaraț dunung ke sěmbajang ke sarea rukin-na ke sarea anung sarusak nja ke sarea sjarat pang dalam rukin(-na); ke i-saněmpas sarea sjaraț wādjib puasa ke sarea sunnat-na ke sarea anung sarusak nja.

Sa-tutu-tutu kami-saněmpas-mo sarea masā'il ${ }^{3}$ ) ta ke pakĕtoan ke panjamong, lema i-totang ling sarea tau běru baladjar, i-apal-mo ling nja sarea masāiil ta. Sa-tutu-tutu lako Allah tacala bae-si kitangeneng tulung, lema tětap agama-kita, ja nan-si agama sa-běnarbĕnar, ke bĕrkat nabi-kita șallā-llāhu 'alayhi wasallam!

Ka tingka i-kĕtoan kita ling tau, apa-po těme-tĕme agama nan, mĕngka samong sa-tutu-tutu těme agama nan, tu-tò Allah ta ala.

Ka tingka i-kětoan kita ling tau, apa-po așal pangetò nan, měngka samong sa-tutu-tutu aṣal pangětò nan tu-sělin antara anung běru ke anung kadīm, kěrana kaněmpas anung harus ada nan, bĕru, ke kaněmpas anung wādjib ada nan, kadīm; mĕngka no-si sama sadua-na ke no-si barĕmin sa-dua(-na) nan.

Ka tingka i-kětoan kita ling tau, me-po anung tu-singin agama nan, měngka samong sa-tutu-tutu anung tu-singin agama nan, 'ibārat tu-sarĕmin anung ěmpat nompo : sai,'’imān; dua, 'islām; tĕlu, tawḥīd; ĕmpat, ma rifat.

Ka tingka i-kětoan kita ling tau, apa-po těgas 'īmān nan, mĕngka samong sa-tutu-tutu tĕgas 'īmān nan, panjadu lako me-me, anung datang ke nja ${ }^{4}$ ) rasul Allah șallā-llāhu 'alayhi wasallam.

Ka tingka i-kětoan kita ling tau, apo-po těgas 'islām nan, mĕngka samong sa-tutu-tutu těgas 'islām nan, tu-djunjung sarea manik Allah ta ala ke tu-sangedò sarea pamĕlang-diri.

1) De Mal. mss.: djunūb.

2) In het ms. gespeld: ulu; de Mal. mss. hebben in plaats van het Arab. woord: mĕngambil air sĕmbahjang.

3) Mal. beter : mas'alah.

4) Het ms. heeft: anung datang, ka pang, maar dit geeft geen goeden zin. Bovenstaande emendatie volgt den Maleischen tekst: barang jang datang děngan dia rasul Allah, d.i. Arab.: mā djā’a bihi rasūlu-1lāhi. 
Ka tingka i-kětoan kita ling tau, apa-po těgas 'ihsān nan, měngka samong sa-tutu-tutu těgas 'ihsān nan, ja nan-si tu-sabalong angan kita lako Allah ta ala serta 'ichlāṣ, tĕgas-na: sampurna kabalong șifat sa-nompo-nompo ling ta, mudi ka-mo tu-dapat ${ }^{1}$ ).

Ka tingka i-kětoan kita ling tau, apa-po těgas tawhīid nan, měngka samong sa-tutu-tutu tĕgas tawhīd nan, ja nan-si tu-samesa, kewa sa-kira-kira no tu-dapat sasai pang anung tu-samesa.

Ka tingka i-kětoan kita ling tau, apa tĕgas ma rifat nan, mĕngka samong sa-tutu-tutu tĕgas ma ${ }^{c}$ rifat nan, ja nan-si tu-tò anung sanompo-nompo sĕrta i-saputis hukum pangĕtò nan kewa nafy ke 'ițāt.

Ka tingka i-kĕtoan kita ling tau, apa-po tĕgas sjahādat nan, mĕngka samong sa-tutu-tutu tĕgas sjahādat nan, ja nan-si pangĕtò lako sanompo-nompo kewa tjiri putis.

Ka tingka i-kĕtoan kita ling tau, pida nompo-po farḍu sjahādat nan, mĕngka samong sa-tutu-tutu farḍu sjahādat nan dua nompo: sai, tu-sěpan ke ela; kadua, tu-satutu ke ate.

Ka tingka i-kětoan kita ling tau, pida nompo-po sampurna sjahādlat nan, mĕngka samong sa-tutu-tutu sampurna sjahādat nan ěmpat nompo: sai, 'ilmu; dua, 'iḳrār; tělu, tașdīk; ěmpat, yakīn.

Ka tingka i-kětoan kita ling tau, pida nompo rukin sjahādat nan, měngka samong sa-tutu-tutu rukin sjahādat nan ĕmpat nompo: sai, tu-satětap dāt Allah ta ${ }^{\mathrm{c}}$ ala; kadua, tu-satětap șifāt Allah ta ${ }^{\mathrm{c}}$ ala; katělu, tu-satětap boat Allah ta ${ }^{c} a l a$; kaěmpat, tu-satětap bĕnar nabikita Muhammad șallā-llāhu 'alayhi wasallam.

Ka tingka i-kětoan kita ling tau, pida nompo-po sjaraț șah sjahādat nan, mĕngka samong sa-tutu-tutu sjaraț șạ̣ sjahādat nan ĕmpat nompo: sai, tò; dua, i-sěpan ke ela; tĕlu, i-satutu ke ate; ĕmpat, tu-boat ling sarea pěrana.

Ka tingka i-kĕtoan kita ling tau, pida nompo-po anung sarusak sjahādat nan, mĕngka samong sa-tutu-tutu anung sarusak sjahādat nan ĕmpat nompo: sai, tu-sadua Allah ta ${ }^{\mathrm{c}}$ ala; kadua, sjak ate-na; katĕlu, no i-aku ka i-pina ling Allah ta ala; ěmpat, no i-satětap dāt Allah ta ${ }^{\mathrm{c}}$ ala.

Ka tingka i-kĕtoan kita ling tau, sjahādat nan pida nompo, mĕngka samong sa-tutu-tutu sjahādat nan dua nompo: sai, sjahādat tawhīid singin-na; kadua, sjahādat rasūl singin.

1) Dit schijnt corrupt te zijn. Het Mal. heeft: mĕnjĕmpurnakan kěelokan șifat suatu kĕmudian dari pada dipěrolehnja. 
Ka tingka i-kětoan kita ling tau, me-po anung tu-singin sjahāelat tawhīd ke me-po anung tu-singin sjahādat rasūl nan, měngka samong sa-tutu-tutu anung tu-singin sjahādat tawhịd nan, ja nan-si 'asjhadu 'an lā 'ilăha 'illā-llāhlu; ke anung tu-singin sjahādat rasūl nan, ja nan-si zo'asjhadu 'anna Muhammadan rasülu-llāhi.

Ka tingka i-kětoan kita ling tau, 'ỉmān nan pida nompo, měngka samong sa-tutu-tutu 'īmān nan dua nompo: sai, 'îmān mudjmal singin; kadua, 'imān mufașsal singin.

Ka tingka i-kĕtoan kita ling tau, pida nompo-po rukin 'īmān mudjmal nan (ke pida nompo-po rukin 'immān mufașạal nan), mĕngka samong sa-tutu-tutu rukin 'îmān mudjmal nan dua nompo : sai, 'āmantu bi-llāhi wabimā ḳāla-llāhu, tĕgas-na: ku-sadu Allah ta ala ke ku-sadu sarea manik Allah ta'ala; kadua; 'āmantu bi-rrasūli wabimā kạlarrasülu, tĕgas-na: ku-sadu rasul Allah ke ku-sadu sarea manik rasul Allah; ke rukin 'imān mufașsal nan nam nompo: sai, 'āmantu bi-llāhi, tĕgas-na: ku-sadu Allah ta'ala; kadua, wamalā'ikatihi, těgas-na: kusadu sarea malaekat-diri; katĕlu, wakutubihi, tĕgas-na: ku-sadu sarea kitab-diri ; kaĕmpat, zvarusulihi, těgas-na : ku-sadu sarea nabi pasurudiri ; kalima, z'a-lyawmi-l'àchiri, tĕgas-na : ku-sadu ano mudi ; kaěnam, wa-lkadari chayrihi wasjarrihi mina-llāhi ta'ālā, těgas-na: ku-sadu sarea djangi těrang ke djangi lěnge datang ka pang Allah ta'ala.

Ka tingka i-kětoan kita ling tau, me-po anung tu-singin djangi těrang nan ke me-po anung tu-singin djangi lĕnge nan, měngka samong sa-tutu-tutu anung tu-singin djangi těrang nan, ja nan-si 'îmān kewa țầat, ke anung tu-singin djangi lěnge nan, kufr kewa ma'siyat.

Ka tingka i-kětoan kita ling tau, pida nompo-po farḍu 'īmān ke sampurna 'īmān nan, mĕngka samong sa-tutu-tutu farḍu 'īmān ke sampurna 'īmān nan tělu nompo: sai, tu-sěpan ke ela; kadua, tusatutu ke ate; katĕlu, i-boat ke sarea pěrana, sĕrta i-turit 'idjmāe șạābat ěmpat, ja nan-si 'Abū Bakr ke ${ }^{\mathrm{C}} \mathrm{Umar}$ ke ${ }^{\mathrm{e}} \mathrm{Uṭmān}$ ke ${ }^{\mathrm{C}} \mathrm{Alī}$.

Ka tingka i-kětoan kita ling tau, pida nompo-po sjarat 'īmān nan, měngka samong sa-tutu-tutu sjarat 'îmān nan sapulu nompo: sai, tu-běri Allah ta ${ }^{\mathrm{a}}$ ala; kadua, tu-běri sarea malaekat-diri; katĕlu, tubĕri sarea kitābu-1lāh; kaěmpat, tu-bĕri sarea nabīyu-llāh; kalima, tu-bĕri sarea walìu-1lāh; kaĕnam, tu-gĕnit sarea musu Allah ta'ala;

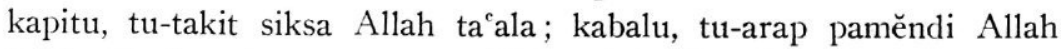
ta'ala; kasiwa, i-sarea pasuru Allah ta ala sěrta i-boat sarea pasuru nan; kasapulu, i-sarea pamělang Allah ta ala sěrta i-sangědò diri ke sarea pamělang nan. 
Ka tingka i-kětoan kita ling tau, pida nompo-po anung sarusak 'īmān nan, měngka samong sa-tutu-tutu anung sarusak 'īmān nan sapulu nompo: sai, tu-sadua Allah ta ala; kadua, i-sakĕkal diri ke sarea boat lĕnge ke $\mathrm{i}$-saharis sarea boat lĕnge nan; katělu, i-sarusak sama machlūk kewa zālim sĕrta i-samogang sjara ${ }^{c}$ Allah ta ${ }^{c} a l a$; kaěmpat, basĕlong sama islam sěrta i-sampe-su pang dalam ate-na; kalima, i-samogang sjarī‘at nabi Allah; (ka)ĕnam, no i-takit gugir 'īmān; kapitu, i-sarupa boat kewa boat tau kāfir; kabalu, i-saputis diri kewa pamĕndi Allah ta ${ }^{\mathrm{C}}$ ala; kasiwa $^{1}$ ) i-kenang pangkenang kāfir měrua tali korok atawa tjĕpeo; kasapulu, i-saputis diri angkang kiiblat sěrta i-samogang-mogang pang clalam ate-na.

Ka tingka i-kĕtoan kita ling tau, pida nompo-po rukin 'islām ran, mĕngka samong sa-tutu-tutu rukin 'islām nan lima nompo: sai, i-sěpan kalimat sjahādat kewa dua kalimat, farḍu pang dalam tu-tělas sa-kali bae-si; kadua, manang sěmbajang pang dalam sa-pětang sa-ng-ano lima wakttu; katĕlu, i-sělis zakāt arta-nja, lamin gěnap niṣāb kewa dapat kěmali kělis ; kaěmpat, puasa bulan Ramaḍān pang dalam sa-tin sa-bulan; kalima, ěntek hadji lako baytu-llāh, lamin koasa balangan lako ana, farḍu sa-kali me-me lè tělas, ke farḍu pang dalam 'islām ${ }^{2}$ ).

Ka tingka i-kĕtoan kita ling tau, pida nompo-po sampurna 'islām nan, mĕngka samong sa-tutu-tutu sampurna 'islām nan tĕlu nompo: sai, tu-sěpan ke ela; kadua, tu-satutu ke ate; katĕlu, tu-boat ke sarea pĕrana.

Ka tingka i-kĕtoan kita ling tau, pida nompo-po tjiri 'islām nan, měngka samong sa-tutu-tutu tjiri 'islām nan ĕmpat nompo: sai, tusaperas diri; kadua, tu-sabrěsi ela kewa bola; katĕlu, brěsi ate-nja kewa kakan anung harām; (ka)ěmpat, brěsi pěrana ${ }^{3}$ ) kewa loba ke țama ${ }^{\mathrm{c}}$.

Ka tingka i-kětoan kita ling tau, pida nompo-po sjarat șah 'islām nan, mĕngka samong sa-tutu-tutu sjaraț șah ’islām nan ĕmpat nompo: sai, șabar lako ḥukum Allah ta'ala; kadua, rabĕta lako kaḍā' Allah ta ala; katělu, jakīn sěrta 'ichlāṣ, těgas-na: sěra diri lako Allah ta"ala; kaěmpat, i-turit manik Allah ta ala ke manik nabi, sěrta i-sangĕdò sarea pamělang-na.

Ka tingka i-kětoan kita ling tau, pida nompo-po anung sarusak 'islām nan, mĕngka samong sa-tutu-tutu anung sarusak ’islām nan

1) Zoo door Junker verbeterd i.p.v. kewa van het oorspr. ms.

2) Wellicht ontbreekt hier iets; de Mal. tekst heeft: dan farḍu dalam 'islām ini djua.

3) Jonker wil ate en pĕrana omwisselen, doch in 't Mal. correspondeert met het eerste pěrut, met het tweede badan. 
ěmpat nompo: sai, i-boat sa-nompo boat nongka kewa pangĕtò; kadua, i-tò, no i-kenang; katělu, no i-tò, no roa lalo baguru; kaĕmpat, i-tjěla tau boat těrang sěrta $i$-saharis tjĕla boat těrang nan.

Ka tingka i-kětoan kita ling tau, pida nompo-po farḍu 'istindjā' nan, mĕngka samong sa-tutu-tutu farḍu 'istindjā' nan tĕlu nompo: sai, tu-sangilang rupa-na; kadua, tu-sangilang rasa-na; katělu, tusangilang mamong-na.

Ka tingka i-kĕtoan kita ling tau, pida nompo-po farḍu maning wādjib ${ }^{1}$ ) nan, měngka samong sa-tutu-tutu farḍu maning wādjib ${ }^{1}$ ) nan tělu nompo: sai, nīyat; ta nja nīyat: (nawaytu raf a-lhadațil'akbari ${ }^{\circ}$ an djamī ${ }^{\mathrm{c}}$-lbadani farḍan li-llāhi, tĕgas-na) saja ku-angkat hadat rea pang sarea pěrana, farḍu karěna Allah; atawa: (nazvaytu raf'a-lhadați mina-ldjinābati farḍan li-llăhi, těgas-na) saja ku-angkat ḥukum hadaț pang djinābat, farḍu karěna Allah; měngka wādjibmo niyat nan pang dalam ate, no-si ${ }^{2}$ ) pang boa bae, kěrana tu-sěpan ke boa nan, sunnat bae-si ; tu-satutu-po ke ate, nan-po wādjib; kadua, i-sanapat (ai) lako sarea pěrana; katělu, i-simpe ${ }^{3}$ ) nědjis pang pěrana.

Ka tingka i-kětoan kita ling tau, pida nompo-po anung wādjib tu-paning nan, měngka samong sa-tutu-tutu anung wādjib tu-paning nan nam nompo: sai, sěbab lis mani-nja; kadua, batěmong dua paloat tau sowai ke tau sĕlaki; katělu, sěbab mate, siong mate sjahīd ${ }^{4}$ ); kaěmpat, sěbab hayḍ; kalima, sěbab wilāda, těgas wilāda nan, tau baranak toar, nonda lis gěti; kanám, sěbab nifās, těgas nifās nan, ja nan-si gěti lis pang mudi ka-mo lis anak, ěmpat-pulu ano atawa nam-pulu ano. Mĕngka sa-kurang-kurang gěti nifās nan sa-patisu ke sa-pĕno-pěno gĕti nifās nan nam-pulu ano [atawa] nam-pulu pĕtang, ke pang kapĕno tau sowai ěmpat-pülu ano ěmpat-pulu pětang. Mĕngka sa-kurang-kurang gěti hayḍ nan sa-pětang sa-ng-ano ke sa-pěno-pěno ${ }^{5}$ ) gěti hayḍ nan lima olas ano lima olas ṕětang, ke pang kapĕno tau sowai nan nam ano nam pětang atawa pitu ano pitu pětang.

Ka tingka i-kĕtoan kita ling tau, pida nompo-po anung harām pang tau djinābat nan, měngka samong sa-tutu-tutu anung harām pang tau djinābat nan lima nompo: sai, sěmbajang; kadua, țawāf; katělu, batja kur’ān; kaěmpat, ěnti kur’ān; kalima, tama měsdjid.

1) De Mal. mss.: djunūb.

2) Zoo door Jonker gecorrigeerd voor no-sa van het origineel.

3) Emendatie van Jonker voor i-simpi.

4) Emendatie van Jonker voor șāhib; ook de Mal. tekst heeft sjahīd.

5) Emendatie van Jonker voor ka-pěno-pěno, 
Ka tingka i-kětoan kita ling tau, pida nompo-po anung ḥarām pang tau hayḍ nan, mĕngka samong sa-tutu-tutu anung harām pang tau hayḍ nan balu nompo: sai, sěmbajang; kadua, țawāf; katělu, batja kur'ān; kaĕmpat, ěnti kur'ān; kalima, tědu pang dalam měsdjid; kanám, lalo datang pang dalam měsdjid; kapitu, puasa; kabalu, țalāk.

Ka tingka i-kĕtoan kita ling tau, pida nompo-po sjaraț maning djinābat nan, měngka samong sa-tutu-tutu sjaraț maning djinābat nan sa-olas nompo: sai, tau 'islām; kadua, tau ada 'akal; katělu, i-tò farḍu ke sunnat; kaěmpat, i-safarḍu anung farḍu ke i-sasunnat anung sunnat; kalima, ke ai sutji bau sasutji anung lin; kaěnam, na ada sa-nompo-nompo, anung pělang ai pang sarea pěrana; kapitu, i-sakěkal totang-nja; kabalu, i-sanapat ai nan lako sarea lenong perrana-nja ke lako pang batěmong bulu pěrana ${ }^{1}$ ); kasiwa, i-pěliara ai nan na rapina pang farḍu; kasapulu, i-sakĕkal nīyat ka ling mula tĕris ka suda maning nan; kasolas, sutji kewa hayḍ kewa nifās.

Ka tingka i-kětoan kita ling tau, pida nompo-po sjarat dunung ke wuḍ̄ì' nan, mĕngka samong sa-tutu-tutu sjaraṭ dunung ke wuḍū' nan nam nompo: sai, 'islām; kadua, tau mumayyiz; katělu, ai sutji bau sasutji anung lin; kaěmpat, na ada anung pělang ai pang pěrana wựū' nan; kalima, sutji kewa hayḍ kewa nifās; kaěnam, i-tò sarea farḍu ke sunnat.

Ka tingka i-kětoan kita ling tau, pida nompo-po farḍu wuḍ̄ì' nan, mĕngka samong sa-tutu-tutu farḍu wuḍū' nan nam nompo : sai, nīyat; ta nja nīyat: (nawaytu raf'a-ḥadați-l'aşghari 'ani-lbadani farḍan $l i$-llāhi, těgas-na) saja ku-angkat hadaț ode pang pĕrana, farḍu karěna Allah; kadua, biso rua; katělu, biso ima sa-dua sanga siku sa-dua ${ }^{1}$ ); kaĕmpat; i-osap sědi lenong otak atawa bulu otak; kalima, biso nè sa-dua sanga mata-manu(k); kaěnam, tartīb; těgas tartīb nan: kĕna riri; tĕgas kĕna riri nan: anung dunung tu-sadunung ke anung mudi tu-samudi.

Ka tingka i-kĕtoan kita ling tau, pida nompo-po anung sarusak wự̄ù' nan, mĕngka samong sa-tutu-tutu anung sarusak wự̣̄' nan lima nompo: sai, apa-apa anung lis langan lawang dua; kadua, i-sĕdu lawang dua ke lampik ima atawa ke gěrangit ima; katělu, basědu lenong tau sĕlaki ke lenong tau sowai, haris nikāh, nonda sampar;

1) Jonker wil lezen: pang batěmong bulu (ke) pĕrana, doch waarschijnlijke: is: pang tumong bulu pěrana, als vertaling van het Mal. těmpat tumbuh roma.

1) Ms.: [sa-dua] ima sa-dua sanga siku; verbeterd naar het Mal.: tangan kĕdua hingga siku kědua. 
kaĕmpat, ilang 'aḳal sěbab boas atawa kupo atawa gila; kalima, tunong no tětap ke katokal; lamin tětap-si katokal, no-si rusak wựī'-nja.

Ka tingka i-kĕtoan kita ling tau, pida nompo-po anung harām pang tau nonda wuḍū' nan, mĕngka samong sa-tutu-tutu anung harām pang tau nonda wuḍū' nan tĕlu nompo: sai, sĕmbajang; kadua, țawāf; katělu, sědu ḳur'ān atawa bawa kưr’ān.

Ka tingka i-kětoan kita ling tau, pida nompo-po sjarat dunung ke sěmbajang nan, měngka samong sa-tutu-tutu sjaraț dunung ke sĕmbajang nan balu nompo: sai, tau 'islām; kadua, tau mumayyiz; katĕlu, i-tò sĕlin farc̣u ke sunnat; kaĕmpat, i-tò tama waḳtu ke zann atawa kewa jaḳin; kalima, tu-lungkap 'awrat; kaĕnam, angkang kiblat kewa dada; kapitu, sutji kewa nědjis no i-ma āf ling sjara ${ }^{c}$ pang pěrana atawa pang kĕre-lamong-nja atawa pang manang sěmbajang atawa pang sudjūdl-na; kabalu, sutji ke hadaț rea (ke hadaț ode).

Ka tingka i-kĕtoan kita ling tau, pida nompo-po tau wädjib sěmbajang nan, měngka samong sa-tutu-tutu tau wādjib sĕmbajang nan tělu nompo: sai, tau 'islām; kadua, tau ada 'akal; katělu, tau bāligh ${ }^{1}$ ).

Ka tingka i-kětoan kita ling tau, pida nompo-po rukin sĕmbajang nan, mĕngka samong sa-tutu-tutu rukin sĕmbajang nan siwa-olas nompo: sai, nīyat; kadua, manang; katělu, takbīratu-l'iḥrām; kaěmpat, batja fātiha; kalima, ruk $\bar{u}^{\mathrm{e}}$; kaěnam, barěnang pang dalam rukū $\overline{\mathrm{c}}^{\mathrm{c}}$; kapitu, 'i'tidāl; kabalu, barĕnang pang dalam 'ítidāl; kasiwa sudjūd; kasapulu, barĕnang pang dalam sudjūd; kasaolas, tokal antara dua sudjūd; dua-olas, barĕnang pang dalam tokal antara dua sudjūd; tělu-olas, sudjūd mudi; ĕmpat-olas, barěnang pang dalam sudjūd mudi; lima-olas, tokal tahīyat 'āchir; nam-olas, barěnang pang dalam tokal tahīyat 'āchir; pitu-olas, batja șalāt; baluolas, salām; siwa-olas, tartīb; tĕgas tartīb nan, ja nan-si : kĕna riri; tĕgas kĕna riri nan: anung dunung tı-sadunung ke anung mudi tt1-samudi.

Ka tingka i-kĕtoan kita ling tau, pida nompo-po sjaraț nīyat nan, mĕngka samong sa-tutu-tutu sjarat nīyat nan pitu nompo: sai, nīyat nan pang dalam ate; kadua, tau 'islām; katĕlu, tau mumayyiz; kaĕmpat; tau ada 'akal; kalima, tau tò-mo sĕlin sĕmbajang (kậā') ke sĕmbajang ('adā'); kaĕnam, i-sarěma nīyat na(n) ke takbīratu-l'iḷrām; kapitu, na rapina nīyat nan.

1) Ms. : tau ada mubaligh; Mal.: kětiga bāligh. 
Ka tingka i-kĕtoan kita ling tau, pida nompo-po sjaraț manang nan, mĕngka samong sa-tutu-tutu sjaraț manang nan sa-nompo-si, ja nan-si, manang sa-kira-kira ruris tolang bangkang, na djulu.

Ka tingka i-kětoan kita ling tau, pida nompo-po sjarat takbiratul'ịhrām nan, mĕngka samong sa-tutu-tutu sjaraṭ takbīratu-l'iḥrām nan sapulu nompo: sai, tu-pěliara sarea ḥurūf-na; kadua, tu-pěliara sarea baris-na; katělu, tu-pĕliara sarea sabdu-na ${ }^{1}$ ); kaĕmpat, tu-pĕliara riri-na; kalima, baturit-turit, na putis; kanam, takbīratu-l'iḥrām nan pang manang, pang tau bau manang; kapitu, na imong wāw pang mutli „Allāhu” nan, měrua Allāhu-w-akbar; kabalı, na imong wāw pang batungku ke hā ḥurūf ${ }^{2}$ ) Allāhu 'akbar; kasiwa, na imong bī nan kewa 'alif hưūîf ${ }^{2}$ ) 'akbar; kasapulu, i-saněmpas pang ela sarea hurūüf balu nan.

Ka tingka i-kětoan kita ling tau, pida nompo-po sjaraț tu-batja fātiḥa nan, mĕngka samong sa-tutu-tutu sjaraṭ tu-batja fātị̣a nan balu nompo: sai, tu-pěliara sarea kalima-na; kadua, tu-pěliara sarea hurưffna; katělu, tu-pěliara sarea baris-na; kaĕmpat, tu-pěliara sarea sabdu-na ; kalima, tu-batja nja pang manang-po, pang tau bau manang; kaĕnam, na putis; kapitu, kěna riri; kabalu, tu-tò fātiḥa nan ka ling mula těris kasuda farḍu pang dalam sĕmbajang.

Ka tingka i-kĕtoan kita ling tau, pida nompo-po sjaraț rukū $\bar{u}^{\mathrm{c}}$ nan, mĕngka samong sa-tutu-tutu sjarat rukü ${ }^{c}$ nan tělu nompo: sai, i-saja tělu ${ }^{3}$ ) ruk $\bar{u}^{\mathrm{e}}$ nan; kadua, i-satingi atas kewa bawa, sa-kira-kira sama asar popong ${ }^{4}$ ) ke sěmodok; katělu, barĕnang pang dalam nan.

Ka tingka i-kětoan kita ling tau, pida nompo-po sjarat 'i 'itidāl nan, mĕngka samong sa-tutu-tutu sjaraț ' $i{ }^{\mathrm{c}}$ tidāl nan ěmpat nompo: sai, i-saja lalo koat ' $i$ 'tidāl nan; kadua, manang koat lako pa(ng) manang kĕbali; katĕlu, i-saja lalo ngangkong lako sudjid nan; kaěmpat, barěnang pang dalam-na.

Ka tingka i-kětoan kita ling tau, pida nompo-po sjaraṭ sudjie nan, mĕngka samong sa-tutu-tutu sjaraț sudjid nan pitu nompo: sai, i-saja lalo sudjid nan; kadua, na ada sampar tata pang mutu sudjid nan; katělu, kanguleng tata pang mutu sudjid nan; kaĕmpat, i-satingi

1) In de Mal. mss. : tasjdid.

2) Ik vermoed dat hurūf hier een verkeerde lezing is voor měrua (Mal. sěpěrti); men leze dus op de eerste plaats: mĕrua Allāhū 'akbar, en op de tweede: měrua 'akbār.

3) tělu zal wel fout zijn; het Mal. heeft disěhadja hĕndak tunduknja; men leze: i-saja lalo rukūic nan.

4) Emendatie van Jonker voor popang. 
popong ke i-saperas otak; kalima, i-olo tata lako pang sudjid nan; kaěnam, i-saperas korok; kapitu, barĕnang pang dalam-na.

Ka tingka i-kětoan kita ling tau, pida nompo-po sjarat tokal [nan] antara dua sudjid nan, mĕngka samong sa-tutu-tutu sjaraț tokal antara dua sudjid nan tělu nompo: sai, i-saja tokal nan; kadua, tokal těrdjang, na djulu; katĕlu, barěnang pang dalam-na.

Ka tingka i-kětoan kita ling tau, pida nompo-po sjaraț tokal tahīyat 'āchir nan, mĕngka samong sa-tutu-tutu sjaraț tokal taḥiyat 'āchir nan tĕlu nompo: sai, i-saja lalo tokal nan; kadua, tokal těrdjang, na djulu; katělu, tětap katokal pang dalam-na.

Ka tingka i-kětoan kita ling tau, pida nompo-po sjarat batja tahìyat 'āchir nan, měngka samong sa-tutu-tutu sjaraț batja tahiyat 'āchir nan pitu nompo: sai, i-pěliara sarea kalima-na; kadua, i-pěliara sarea hurūf-na; katĕlu, i-pěliara sarea baris-na; kaĕmpat, tu-pěliara sarea sabdu-na; kalima, na putis; kanám, kěna riri; kapitu, tu-batja nja pang tokal tawāruk, pang tau bau tokal tawāruk.

Ka tingka i-kĕtoan kita ling tau, pida nompo-po sjarat batja șalāt nan, mĕngka samong sa-tutu-tutu sjaraț tu-batja șalāt nan pitu nompo: sai, tu-pĕliara sarea kalima-na; kadua, tu-pěliara sarea hurūf-na: katĕlu, tu-pěliara sarea sabdu-na; kaĕmpat, tu-pĕliara sarea baris-na; kalima, na imong ḥurūf; kaĕnam, na putis; kapitu, kěna riri.

Ka tingka i-kětoan kita ling tau, pida nompo-po sjaraṭ salām na(n), měngka samong sa-tutu-tutu sjaraṭ salām nan ěmpat nompo: sai, tupĕliara sarea kalima-na; kadua, tu-pěliara sarea baris-na; katĕlu, tupěliara sarea sabdu-na; kaĕmpat, salām nan pang tokal-po, pang tau bau tokal.

Ka tingka i-kětoan kita ling tau, pida nompo-po sjarat tartīb nan, měngka samong sa-tutu-tutu sjaraț tartīb nan sa-nompo-si, ja nan-si : anung dunung tu-sadunung ke anung mudi tu-samudi. 


\section{AANVULLING EN VERBETERING.}

In het artikel „Eenige recente vondsten in het Rijksmuseum van Ethnographie" van Dr. J. F. Stutterheim komt op p. 178 dezer Bijdragen de volgende zinsnede voor:

„Het is misschien dienstig tevens te dezer plaatse te wijzen op het feit, dat we in de portefeuille D II $\mathrm{E}$ o.a. een zestal teekeningen aantreffen in potlood van Hindoe-Javaansche oudheden, die langen tijd te Dordrecht vertoefd hebben en onlangs door Prof. van Eerde naar Amsterdam zijn gebracht".

Ter voorkoming van alle misverstand stelt laatstgenoemde er prijs op uit te doen komen, dat het overbrengen uit Dordrecht naar Amsterdam slechts slaat op de beelden, niet op de teekeningen, die het Rijksmuseum nooit hebben verlaten. Ook zijn de beelden niet onlangs, doch reeds in 1915 an het Koloniaal Instituut geschonken, door de erven van den Heer F. Lebret te Dordrecht (zie Jaarversl. Kol. Inst. 1915, p. 34).

RED. 
